Portland State University

PDXScholar

\title{
Studies of ecological factors that affect the population and distribution of the western gray squirrel in northcentral Oregon
}

Susan Ann Foster

Portland State University

Follow this and additional works at: https://pdxscholar.library.pdx.edu/open_access_etds

Part of the Environmental Indicators and Impact Assessment Commons, and the Environmental Monitoring Commons

Let us know how access to this document benefits you.

\section{Recommended Citation}

Foster, Susan Ann, "Studies of ecological factors that affect the population and distribution of the western gray squirrel in northcentral Oregon" (1992). Dissertations and Theses. Paper 2383.

https://doi.org/10.15760/etd.2380

This Dissertation is brought to you for free and open access. It has been accepted for inclusion in Dissertations and Theses by an authorized administrator of PDXScholar. Please contact us if we can make this document more accessible: pdxscholar@pdx.edu. 
STUDIES OF ECOLOGICAL FACTORS THAT AFFECT THE

POPULATION AND DISTRIBUTION OF THE WESTERN GRAY SQUIRREL

IN NORTHCENTRAL OREGON

by

SUSAN ANN FOSTER

A dissertation submitted in partial fulfillment

of the requirements for the degree of

DOCTOR OF PHILOSOPHY

in

ENVIRONMENTAL SCIENCES AND RESOURCES:

BIOLOGY

Portland State University

-1992 


\section{TO THE OFFICE OF GRADUATE STUDIES:}

The members of the Committee approve the dissertation of Susan Ann Foster presented January 10, 1992.

Richard B. Forbes, Chair

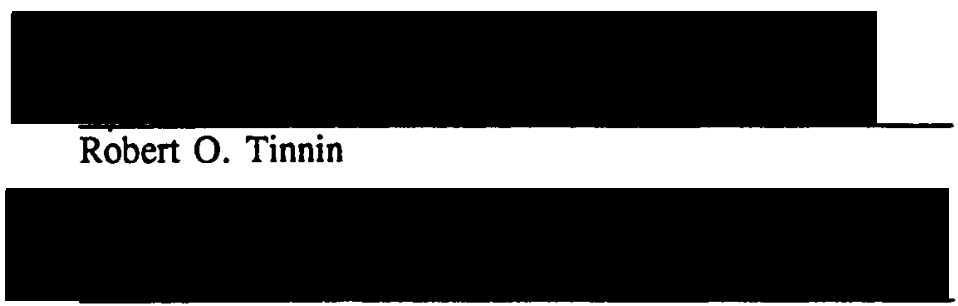

Richard R. Petersen

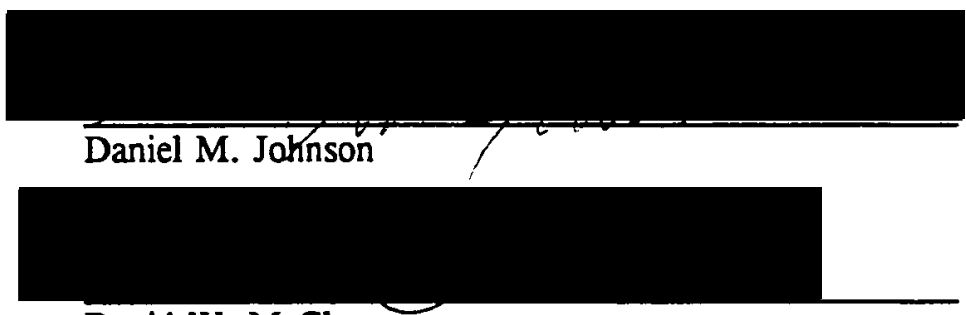

David W. McClure

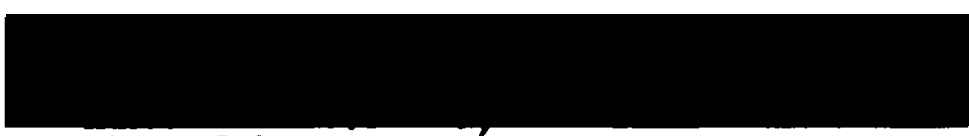

Thomas Palm

\section{APPROVED:}

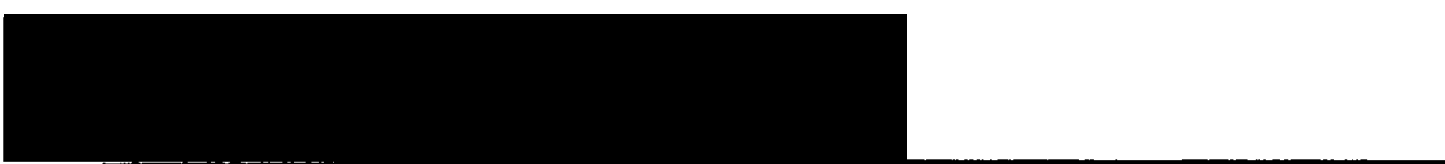

Robert O. Tinnin, Chair, Department of Biology

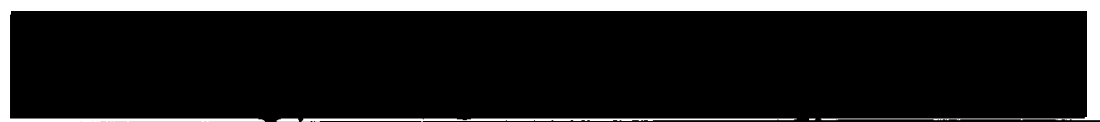

C. William Savery, Interim Vice Provost for Craduate Studies and Research 


\section{ACKNO'VLEDGEMENTS}

I thank the many people who have encouraged me in the process of this dissertation, especially Professors Richard Forbes, Robert Tinnin, and Richard Petersen. Professors David McClure, Daniel Johnson and Thomas Palm provided many helpful comments. I am especially grateful to my friends, Ellen Benedict, Ruth McFarland and Sally Martin, who endured subzero and $110^{\circ} \mathrm{F}$ weather with me measuring, tracking, and sampling parts. I am indebted to the Dental Hygiene Lab at Mt. Hood Community College for use of their x-ray equipment and expertise, the CAD lab personnel for their patience, and the Science Division for frequent manipulation of my schedule to allow me time to do this research. I thank Donald Crimmins, DVM, of the Rockwood Animal Clinic for information and consultation. I am grateful for the typing skills of Darlene Maddox and her assistance in editing this dissertation.

Finally, I would like to acknowledge the continued faithful companionship of Patti, the wonder dog. 
TABLE OF CONTENTS

PAGE

ACKNOWLEDGEMENTS $\ldots \ldots \ldots \ldots \ldots \ldots \ldots \ldots \ldots$ iii

LIST OF TABLES $\ldots \ldots \ldots \ldots \ldots \ldots \ldots \ldots \ldots \ldots \ldots \ldots \ldots$ vii

LIST OF FIGURES $\ldots \ldots \ldots \ldots \ldots \ldots \ldots \ldots \ldots \ldots \ldots \ldots \ldots \ldots \ldots$

\section{CHAPTER}

I INTRODUCTION $\ldots \ldots \ldots \ldots \ldots \ldots \ldots \ldots \ldots \ldots$

II REVIEW OF THE LITERATURE $\ldots \ldots \ldots \ldots \ldots \ldots \ldots$

Habitat Requirements . . . . . . . . . . . 6

Nests and Nest Trees ............... 8

Food Habits $\ldots \ldots \ldots \ldots \ldots \ldots \ldots \ldots$

Home Range $\ldots \ldots \ldots \ldots \ldots \ldots \ldots \ldots \ldots$

Age Determination $\ldots \ldots \ldots \ldots \ldots \ldots \ldots \ldots \ldots$

Reproduction ................. 13

III STUDY AREA $\ldots \ldots \ldots \ldots \ldots \ldots \ldots \ldots \ldots \ldots$

IV METHODS AND MATERIALS . . . . . . . . . ... 19

Food Habits $\ldots \ldots \ldots \ldots \ldots \ldots \ldots \ldots \ldots$

Live Trapping $\ldots \ldots \ldots \ldots \ldots \ldots \ldots \ldots \ldots$

Home Range $\ldots \ldots \ldots \ldots \ldots \ldots \ldots \ldots \ldots$ 
Age Determination $\ldots \ldots \ldots \ldots \ldots \ldots \ldots \ldots$

Habitat Requirements . . . . . . . . . . . . . . 24

v $\quad$ RESULTS .......................... 27

Food Habits $\ldots \ldots \ldots \ldots \ldots \ldots \ldots \ldots \ldots \ldots \ldots$

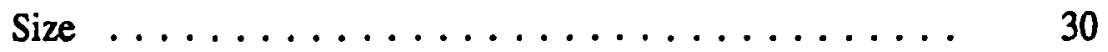

Reproduction and Growth ............. 30

Live-Trapping Results $\ldots \ldots \ldots \ldots \ldots \ldots \ldots \ldots$

Home Range ..................... 44

Age Determination $\ldots \ldots \ldots \ldots \ldots \ldots$

Nest Trees $\ldots \ldots \ldots \ldots \ldots \ldots \ldots \ldots \ldots \ldots \ldots$

VI $\quad$ DISCUSSION $\ldots \ldots \ldots \ldots \ldots \ldots \ldots \ldots \ldots$

VII CONCLUSIONS AND RECOMMENDATIONS ...... 83

Conclusions .................... 83

Recommendations ................. 84

REFERENCES CITED AND ADDITIONAL LITERATURE . . . . . . 87 APPENDICES

A HUNTER COOPERATION PROGRAM INFORMATION

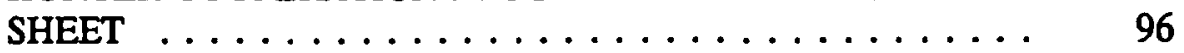

B RAW DATA FROM HUNTER COOPERATION PROGRAM INCLUDING HUNTING SEASON ROADKILLS AND

ANIMALS OBTAINED FROM OREGON

DEPARTMENT OF FISH AND WILDLIFE AND

OREGON STATE POLICE PERSONNEL

FOR STOMACH CONTENT ANALYSIS 
C NEST TREE SITE MAPS . . . . . . . . . . . . . 133

D NEST BOX DESIGN ................... 153 


\section{LIST OF TABLES}

TABLE

PAGE

I Stomach Content Analysis of 14 Western Gray Squirrels,

$$
1981-1984 \ldots \ldots \ldots \ldots \ldots \ldots \ldots
$$

II Size of Live-Trapped Squirrels . . . . . . . . . . . 31

III Data on Reproductive Status of Live-Trapped Female

Squirrels $\ldots \ldots \ldots \ldots \ldots \ldots \ldots \ldots \ldots \ldots \ldots$

IV Data on Reproductive Status of Live-Trapped Male Squirrels . . . 33

V Data on Lactating Female Squirrels Taken in the Hunter

$$
\text { Cooperation Program, August-November, 1981-1987 . . } 34
$$

VI Results of Live Trapping, 1981-1986 . . . . . . . . . . 38

VII Recaptured Western Gray Squirrels ............... 39

VIII Sex Ratios and Capture Rates for Live-Trapped Westem

Gray Squirrels . . . . . . . . . . . . . 42

IX Main Trap Competitors, $1981-1986 \ldots \ldots \ldots \ldots \ldots \ldots \ldots$

X Other Species Trapped, $1981-1986 \ldots \ldots \ldots \ldots \ldots \ldots$

YII Home Ranges of Eight Western Gray Squirrels . . . . . . . . 45

XII Squirrels from Hunter Cooperation Program Arranged by

Sex and Age $\ldots \ldots \ldots \ldots \ldots \ldots \ldots \ldots . \ldots \ldots$

XIII Skull Measurements of Known-Age Squirrels . . . . . . . . . 50 
XIV Site Characteristics $\ldots \ldots \ldots \ldots \ldots \ldots \ldots \ldots$

XV Nest Tree and Non-Nest Tree Characteristics ........... 55

XVI Percentage of Cover in One-Fifth Acre Plot of Nest

Tree Sites $\ldots \ldots \ldots \ldots \ldots \ldots \ldots \ldots \ldots$

XVII Basal Area of Nest Tree Sites ................. 60 


\section{LIST OF FIGURES}

FIGURE

PAGE

1. Study Area ........................ 16

2. Site Measurements of Nest Tree Sites ............ 25

3. Numbers of Squirrels of Each Age Category Taken in the Hunter Cooperation Program, 1981-1987. . . . . . . . . . 48

4. Mean, Standard Deviation, and Range of Greatest Skull Length of Squirrels Taken in the Hunter Cooperation Program, 1981-1987.

5. Mean, Standard Deviation, and Range of Least Interorbital Breadth of Squirrels by Age Taken in the Hunter Cooperation Program, 1981-1987 . . . . . . . . . . . . . . . . 52

6. Nest Tree Site $072 \ldots \ldots \ldots \ldots \ldots \ldots \ldots \ldots \ldots$

7. Nest Tree Site $081 \ldots \ldots \ldots \ldots \ldots \ldots \ldots \ldots \ldots \ldots \ldots$

8. Nest Tree Site $089 \ldots \ldots \ldots \ldots \ldots \ldots$

9. Nest Tree Site $091 \ldots \ldots \ldots \ldots \ldots \ldots \ldots \ldots$

10. Nest Tree Site $092 \ldots \ldots \ldots \ldots \ldots \ldots$

11. Cutaway Side View of a Westem Gray Squirrel Nest Taken From

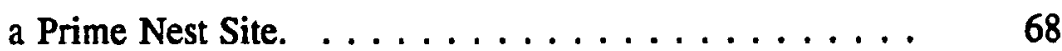


AN ABSTRACT OF THE DISSERTATION OF Susan Ann Foster for the Doctor of Philosophy in Environmental Sciences and Resources: Biology, presented January 10, 1992.

Title: Studies of Ecological Factors That Affect the Population and Distribution of the Western Gray Squirrel in Northcentral Oregon

APPROVED BY MEMBERS OF THE DISSERTATION COMMITTEE:

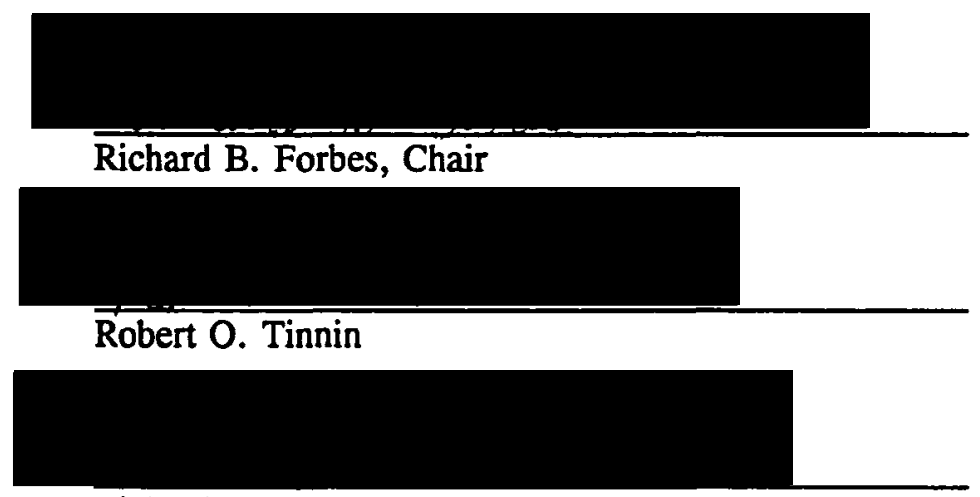

Richard R. Petersen

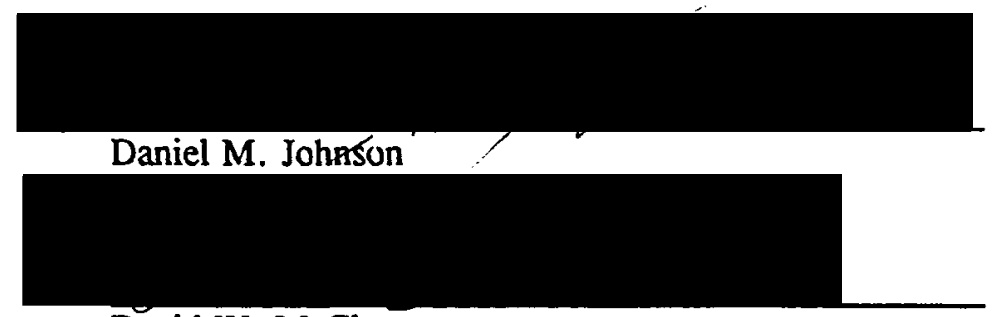

David W. McClure

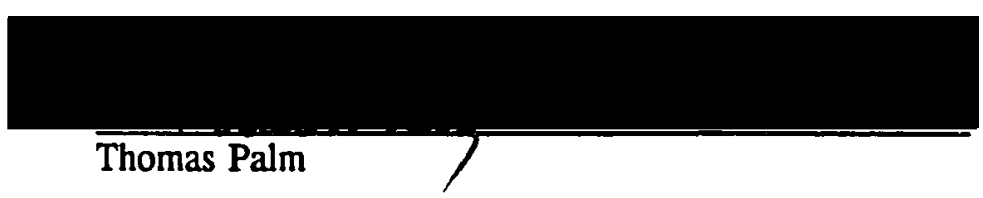


The western gray squirrel (Sciurus griseus griseus Ord) occur only in the Pacific states and in a small corner of extreme western Nevada. Field studies of aspects of the ecology of the most widely distributed subspecies of western gray squirrel (S. griseus) were conducted at three sites in the ponderosa pine-Oregon white oak zone on the eastern slopes of Mt. Hood, Wasco County, Oregon, between 1981 and 1989. From 1981 through 1987, a Hunter Cooperation Program provided remains of squirrels shot during the annual late summer-early autumn hunting season. Other data were gathered through capture and release studies, radiotelemetry, and habitat analysis.

The age structure of these populations, as revealed by examination of squirrels killed by hunters, is predominantly mature animals. Also, the population as estimated by hunter success during the Hunter Cooperation Program and by field observations appears to be declining.

In the sites studied, western gray squirrels have two seasons of reproductive activity annually. Some individuals mate from January through March; their young emerge from the nest in May and June. Other individuals mate during May and June; their young emerge in August and September. The latter matings are usually the most productive.

Analysis of nest trees and their surroundings revealed that nests are most likely to be located in mature trees that have well-developed crowns and occur in stands with a high degree of canopy closure. Nest trees were usually located within 
approximately 180 meters of permanent water and on sites with a south-southeasterly exposure.

Home ranges of squirrels examined in this study were usually large compared to home ranges reported for this species elsewhere in its range. Given the cost of having large home ranges, it seems possible that the squirrels at these study sites exist in less than optimal ecological circumstances.

Human factors that may have contributed to the decline of the populations in this study may include the nature of logging activities and the timing of the annual hunting season. Limiting factors other than human activities may include competition with other mast-consuming animals (mule deer, elk, wild turkeys, and three other species of squirrels) for limited and variable mast crops. 


\section{CHAPTER I}

\section{INTRODUCTION}

The western gray squirrel, Sciurus griseus griseus Ord, is the largest native tree squirrel in the western United States, yet little is known of its habitat requirements, life history, or population biology. The various subspecies of this squirrel occur in the western forested regions of the mountains and lowlands of the Pacific Coastal States (E. R. Hall, 1981). Its range extends from the northern Cascades in Washington through the Cascade and Coast ranges in Oregon and through the coastal and Sierra Nevada mountains of California. S. griseus, which is associated with a variety of conifers throughout its range, is also found in the ponderosa pine-Oregon white oak association on the eastern slopes of Mt. Hood.

The management status of the western gray squirrel population in northcentral Oregon is mixed. The Oregon Department of Fish and Wildlife has classified S. griseus as a game animal, and it is hunted in the fall. The Mt. Hood National Forest has classified it as a management indicator species for ponderosa pine-Oregon white oak associations. As an indicator species, the status and health of populations of $S$. griseus presumably indicate the quality of the habitat within which it lives. This presents a dilemma in management practices for the western gray squirrel, as it is difficult to set bag limits and hunting season dates with little information of the animal's reproductive biology. It is also difficult to provide adequate nesting sites, 
food sources, space, and to monitor an indicator species when little is known of its habitat requirements. This study was designed to answer certain questions on the food habits and competitors, habitat requirements for nesting, cover and water, nest tree requirements, population structure and reproductive activities of the western gray squirrel in northcentral Oregon.

The study began in 1981 with a preliminary survey of the western gray squirrel habitats along a transect from Oregon southward to the limit of the range of the species in southem Califomia. This permitted comparisons of prime and peripheral western gray squirrel habitats along a substantial latitudinal gradient and under a variety of different habitat types-tanoak (Lithocarpus densiflora var. echinoides),' pinyon pine (Pinus monophylla), California live oak (Quercus chrysolepis), Pacific madrone (Arbutus menziesii), and various hardwood riparian species. The regions observed included the coastal mountains of both Oregon and California, the eastern slopes of the Sierra Nevada mountains, and the mountains of southem Oregon.

Following this brief survey of western gray squirrel habitats, a study area was selected in the ponderosa pine-Oregon white oak (Pinus ponderosa-Quercus garryanna) association located in Wasco County, Oregon. The study area extends from The Dalles south to the White River, on the eastern slope of Mt. Hood. This area supports a number of western gray squirrels and is open to hunting of that species from late August to early November annually.

'Scientific names and common names of plants are from Hitchcock and Cronquist (1973), mammals are from E. R. Hall (1981) and birds are from Peterson (1991). 
The status of the western gray squirrel differs throughout its range. In Washington, the species is presently classified as a sensitive species, and an application has been made to upgrade this classification to threatened (Rodrick, 1987). In Oregon, the western gray squirrel is regarded as a pest in the agricultural areas of walnut and filbert orchards of northwestern Oregon, as a game animal in southwestern and northcentral Oregon, and as a non-game species in the remainder of its range. In California the western gray squirrel is a valued game animal over most of its range.

Much of the range of this species is on multiple-use land, and prime habitat for these squirrels is being lost or seriously altered through ignorance of basic information relevant to management of the species. Merriam's wild turkey (Meleagris gallopavo), mule deer (Odocoileus hemionus) and Rocky Mountain elk (Cervus elaphus) have also been listed as management indicator species for the ponderosa pine-Oregon white oak association of the Mt. Hood National Forest (Topik, Halverson \& High, 1988).

The western gray squirrel is one of several species of small mammals that are important in the dispersal of hypogeous fungal spores. This role may be critical in the growth, health and survival of coniferous forests (Fogel \& Trappe, 1978; Maser, Trappe, \& Ure, 1978). Because western gray squirrels bury nuts singly, the squirrels are also considered important vectors for the dispersal of seeds from several species of trees, in particular various species of oaks.

This study, therefore, should be valuable in two ways. It provides information worthwhile to science in general and wildlife management in particular concerning 
factors limiting the occurrence and abundance of a native northwestern species whose ecological distribution and numbers are little known. Secondly, based on information acquired in this study and in the literature, management recommendations for westem gray squirrels were formulated with particular reference to their specific habitat requirements. 


\section{CHAPTER II}

\section{REVIEW OF THE LITERATURE}

A number of studies have dealt with aspects of history, ecology and populations of various tree squirrels. Seton (1928) published accounts of the habits of various game animals, including eastern gray squirrel (Sciurus carolinensis), fox squirrel (Sciurus niger), red squirrel (Tamiasciurus hudsonicus), Douglas' squirrel (Tamiasciurus douglasii), and the westem gray squirrel). The western gray squirrel is often considered to be sufficiently like the eastern gray squirrel in the length and nature of the reproductive cycle, the trees required for den trees, the construction and use of nest boxes, and food habits so that the information gathered from eastern gray squirrels has been used as a guide for management of western gray squirrels (Seton, 1928).

Taxonomically, however, the western gray squirrel is placed in its own subgenus, Hesperosciurus, while the eastern gray squirrel is in the subgenus Neosciurus (E. R. Hall, 1981). Studies of the bacula of squirrels (Pocock, 1923; Wade \& Gilbert, 1940) indicate that there is a close phylogenetic relationship between the eastem gray squirrel, the fox squirrel, and the red squirrel, while the western gray squirrel and Abert's squirrel (Sciurus aberti) have similar bacula. Recent studies of both Abert's squirrel (Patton, 1984) and Kaibab squirrel (Sciurus aberti kaibabensis) (J. G. Hall, 1981) indicate similarities to the western gray squirrel in nest tree 
selection, habitat utilization and food habits. The western gray squirrel is generally

thought to have habits similar to those of the eastern gray squirrel in their respective niches, but no genetic interchange would have been possible between these species until recently when easterm gray squirrels were introduced into western gray squirrel habitat. The only tree squirrels native to the western Unites States are Douglas' squirrel, red squirrel, northern flying squirrel (Glaucomys sabrinus), Abert's squirrel, Arizona gray squirrel (Sciurus arizonensis) and westem gray squirrel (Barnum, 1975; Brown, 1984).

\section{HABITAT REQUIREMENTS}

Habitat suitability indices produced for the Forest Service by Miller (1984) and additional work by Rodrick (1987), Cross (1969), Gilman (1986), Byrne (1979) and Asserson (1974) show that western gray squirrels need a mix of mast-producing trees to provide both food, cover and nesting sites in their habitat. The ecological range of the western gray squirrel includes a variety of habitat types with mixed conifer-oak forests. The species of oaks vary considerably within the range. Generally, the squirrels require trees of a size sufficient to produce an interconnected canopy for aerial travel, as the squirrels are extremely wary and secretive (Hall, 1980b; Miller, 1984; Rodrick, 1987). Cross (1969) gathered information on the daily activity patterns, nest sites, nest trees, and habits of the western gray squirrel in southern Oregon from 1965 to 1968 . The study included a discussion of the habitat types used by the squirrels. Vegetation types included areas of primarily oaks with scattered 
ponderosa pines and Douglas-fir (Pseudotsuga menziesii), and areas with a higher density of ponderosa pine, Douglas-fir, Oregon white oak, California black oak (Quercus kelloggii), and Pacific madrone. Byme (1979), in a study of the interactions of eastern gray squirrels and fox squirrels with western gray squirrels in California, concluded that displacement of western gray squirrels by the two introduced species occurred due to habitat changes from plantings of cultivated fruits and nuts and the production of two litters per year by fox and eastern gray squirrels as opposed to one litter per year by the western gray squirrels. These differences allowed the two introduced species to replace the western gray squirrels when population numbers of the latter were low rather than displacing them through competition for available habitat or food.

Timber harvest represents an intensive habitat disruption by humans. Studies of Abert's squirrel populations and their habitats show that these squirrels are negatively influenced by forest management practices that lead to even-age stands of ponderosa pine (Patton, 1984). Asserson (1974) concluded that clear-cutting of merchantable timber involved the eradication of mast-bearing trees in the habitat of the western gray squirrel. The same results were noted following a fire in part of the study area. Observations of the burn showed little use of the area by tree squirrels. Asserson's study also noted that various age classes of oaks, including old live and dead trees, were needed to provide both food and cover, and different age categories of conifers were important for year-round cover and seasonally important food. The distribution of trees, size of trees and the patchiness of the environment appear to be factors 
affecting abundance of and habitat selection by Abert's squirrels (Farentinos, 1972;

J. G. Hall, 1981; Keith, 1965; Patton, Wadleigh, \& Hudak, 1985; Pederson, Hasenyager, \& Heggenet, 1976; Vahle \& Patton, 1983).

\section{NESTS AND NEST TREES}

Nest boxes have been utilized in different forest types in an attempt to increase the availability of dens in areas lacking sufficient den trees. In the eastern and southern forests occupied by eastern gray and fox squirrels, nest boxes have been helpful in increasing squirrel populations (McComb \& Noble, 1981). Several investigators have suggested that western gray squirrels utilize den trees for winter nesting or for rearing of young, although this appears to vary over the species' range (Asserson, 1974; Barnum, 1975; Cross, 1969; Ingles, 1947; Maser, Mate, Franklin, \& Dymess, 1981).

Nests built by western gray squirrels are generally of two types: large twig and leaf nests constructed with a roof of varying thickness for winter use and rearing of young, and looser leaf nests or "drays" constructed as temporary nests, summer nests or altermative nests (Cross, 1969; Ingles, 1947). Winter and rearing nests were usually built in conifers, while drays were often built in various species of deciduous trees. The selection of a nest tree for the winter or rearing nest is relatively dependant upon tree size and species (Asserson, 1974; Barnum, 1975; Cross, 1969; Rodrick, 1987) throughout the western gray squirrel's range. This is in agreement 
with the information available for both Abert and Kaibab squirrels (J. G. Hall, 1981; Keith, 1965; Patton, 1984).

\section{FOOD HABITS}

Barnum (1975) indicated that western gray squirrels were not present in areas where there were only single sources of food. Stienecker and Browning (1970) analyzed the stomach contents of 310 western gray squirrels collected from 1963 to 1968. This study was updated in 1977 with the addition of 207 samples collected between 1968 and 1970 from five more counties to supplement the data from seven counties originally studied (Stienecker, 1977). Food patterns were found to be similar through the seven years of the study, although some variations were noted in species of fungus eaten in different forest associations. These studies found that one of the major components of the squirrels' diet was hypogeous fungi. Studies of the implications of mycophagy by small mammals have highlighted the importance of hypogeous fungi in the diet of western gray squirrels (Maser, Trappe, \& Nussbaum, 1978; Maser, Trappe, \& Ure, 1978; Stienecker, 1977). These studies have emphasized the importance of the interrelation of mycophagous mammals and the coniferous forests within which they live. The hypogeous fungi eaten by these squirrels and other small mammals are mycorrhiza-forming fungi upon which coniferous trees depend for the uptake of nonmobile minerals from the soil, while the fungi depend upon the trees for photosynthetic products. This mutualistic relationship allows for extensively increased surface area for absorption of these soil nutrients. 
The Pinaceae, to which ponderosa pine belongs, are particularly dependent upon these fungi. In addition to their absorptive function, these fungi produce growth regulators that increase both the life of the rootlets and the number of root tips, and increase disease resistance (Maser, Trappe, \& Ure, 1978). The hypogeous fungi depend upon mycophagous small mammals for dissemination of spores. As the squirrels travel and defecate, undigested fungal spores are shed on the soil. Eventually, the spores wash down to the roots of seedlings (J. G. Hall, 1981; Maser, Trappe, \& Nussbaum, 1978). Hypogeous fungi have a higher food value, including salts, phosphorus and protein, than epigeous fungi although the hypogeous fungi are lower in water content (Stienecker, 1977; Stienecker \& Browning, 1970). The foods of the introduced eastern gray and fox squirrels in California apparently do not include hypogeous fungi, although epigeous fungi were found in their diets. These two squirrels were more dependent upon human-introduced food sources such as nut orchards and cultivated foods (Byrne, 1979). Pine mast appears to be critically important in the diet of the western gray squirrel, especially in the summer and fall when the seeds have reached the milk stage. Pine seeds are high in iron and carbohydrates and contribute to the deposition of fat for winter (Stienecker, 1977; Stienecker \& Browning, 1970). Cross (1969) found that pine and fir seeds were eaten all year and were eaten almost exclusively in late summer and early fall. Acoms were eaten from late fall through winter. Hypogeous fungi formed a major portion of the spring and early summer diet and were probably utilized all year. Unlike Abert's squirrels, western gray squirrels cache winter food stores. The mast is buried individually in 
holes in the ground. Most of the foraging by western gray squirrels occurs on the ground except in the fall when they cut green cones for food and for winter storage.

The western gray squirrel is considered to be a pest in areas of Oregon where its natural habitat is abutted by nut groves and pear orchards. Squirrels may cause a great deal of damage to these crops (Byme, 1979; Rodrick, 1987). Westem gray squirrels and Abert's squirrels are known also to feed upon the cambial layer of twigs of the ponderosa pine trees. The squirrels utilize this rich food layer in winter and early spring when sap is running. Abert's squirrel, the diet of which is much more dependent upon ponderosa pine due to a lack of other mast in its range, also feeds upon the cambial layer, but the damage is not considered sufficient to label the animal a pest. It was noted that although an individual tree may slow its growth for a season or two, the overall growth of the tree was not significantly different from nonfeeding trees (J. G. Hall, 1981). The problem with western gray squirrels' use of cambium is localized but may cause significant damage to individual trees (Baldwin, 1980; Cross, 1969; Swift, 1977).

\section{HOME RANGE}

All animals have minimum requirements for food, cover and other necessities to sustain life. These requirements are met in that area called the habitat of the animal. The suitability of habitat is determined in part by the amount of space required to meet the animal's food, cover, nesting and reproductive needs. This space is referred to as the home range of the animal. Home range information for western gray 
squirrels has been obtained by visual observation (Ingles, 1947), use of trapping grids (Asserson, 1974; Barnum, 1975; Hall, 1980a), and by radiotelemetry (Cross, 1969;

Gilman, 1986). Rodrick (1987) used track stations in an attempt to determine presence of squirrels in Washington.

\section{AGE DETERMINATION}

Determination of the age structure of a population requires that a method exist to determine the age of individuals in the population. Many methods have been used for this purpose. Eye lenses of many mammals grow continuously throughout their lives. Lord (1959) used this fact to construct a graph of eye lens weights for animals of known ages. The presence and amount of epiphyseal cartilage permits separation of mammals into three classes: juveniles have a wide band of cartilage, subadults have a narrow band, and adults have no epiphyseal cartilage remaining (Carson, 1961). Asserson (1974) used this method to determine relative ages of western gray squirrels. Eruption, replacement, and wear pattern of the molariform teeth of the mandible permits separation of mammals into juvenile, subadult, adult and old adult age classes (Forbes, 1966; Hench, Kirkland, Setzer, \& Douglass, 1984; Nellis, 1969).

Other methods used to determine ages of squirrels include the color and condition of genitals and mammae (Allen, 1952; Barrier \& Barkalow, 1967), dried lens weight (Fisher \& Perry, 1970), degree of epiphyseal closure in long bones (Petrides, 1951) and pelage coloration (Sharp, 1958). 
With the addition of more recent studies involving ossification, tuberosities, and adhesion lines in the mandibles, some controversy has arisen over the use of tooth eruption and wear patterns (Sullins, McXay, \& Verts, 1976). The other methods are also controversial. For example, Colburn (1986) studied the degree of long bone ossification and the correlation of this to the development of suspensory tuberosities on the ischial arches of the innominate bones in eastern gray, fox, and red squirrels and eastern chipmunks. The suspensory tuberosities serve as attachment points for the ligaments that support the penis. The method is useful only up to $10-13$ months of age and only in male animals. Recent studies suggest the presence of darkly stained adhesion lines in the mandible of various mammals is a method of promise, although there are some animals that show no such lines and are known to be the young of the previous year (Costain \& Verts, 1982; Fiero \& Verts, 1986; Livezely \& Verts, 1979; Sullins, et al., 1976). Although these methods are useful for differentiating between juveniles and adults, they are not sufficient to separate animals into more than these two age classes.

\section{REPRODUCTION}

Several investigators have noted the presence of two major reproductive peaks during a single long breeding season that begins in January among western gray squirrels (Bailey, 1936; Byrne, 1979; Cross, 1969; Ingles, 1947; Swift, 1977). In these studies the major production and recruitment of young into the population occurs from the summer litter or second major reproductive peak. 
Asserson (1974) studied reproductive cycles and parturition of the western gray squirrel in Kern County, California, from 1968 to 1976. He found evidence of spring and summer litters. He used information from Game Take Hunter Surveys to show that less than $5 \%$ of the population was taken by hunters each season.

Cross (1969) noted that western gray squirrel females become sexually mature at 10 to 11 months of age, and that older females could potentially have two litters a year. Other studies, however, have produced little evidence that any individual female produced more than one litter a year (Asserson, 1974; Bryne, 1979; Rodrick, 1987; Swift, 1977). 


\section{CHAPTER III}

\section{STUDY AREA}

This study was conducted on the east slopes of Mt. Hood in the ponderosa pine-Oregon white oak zone (Franklin \& Dymess, 1973). Integrated into this zone are Douglas-fir, western hemlock (Tsuga occidentalis), black cottonwood (Populus nigricans), and grand fir (Abies grandis). The area is generally characterized by dry, warm summers and moist, cold winters with most of the precipitation falling as snow during winter. Average annual precipitation ranged from 7.77 in. $(19.7 \mathrm{~cm})$ to $27.6 \mathrm{in} .(70.2 \mathrm{~cm})$ for $1981-1989$. Average annual temperature ranged from $7.78^{\circ} \mathrm{C}$ to $10.56^{\circ} \mathrm{C}$ for $1981-1989$ (U.S. Department of Commerce, National Weather Service, Portland, Oregon). Frost is possible during any season of the year.

The study area was approximately $80.5 \mathrm{KM}^{2}$. It extended from Fifteen Mile Creek in the north to the White River in the south, and included lands in the Barlow Ranger District of the Mt. Hood National Forest, the White River Game Management area of the Oregon Department of Fish and Wildlife, and private lands. The range in elevation was from 460 to $1070 \mathrm{~m}$. Studies were concentrated in three primary areas: Bear Gulch-Jordan Creek, located within the Oregon Department of Fish and Wildlife land; Onion Flats, located on Mountain Fir Lumber Company land; and the Out Timber Sale, located on U. S. Forest Service land (see Figure 1). 


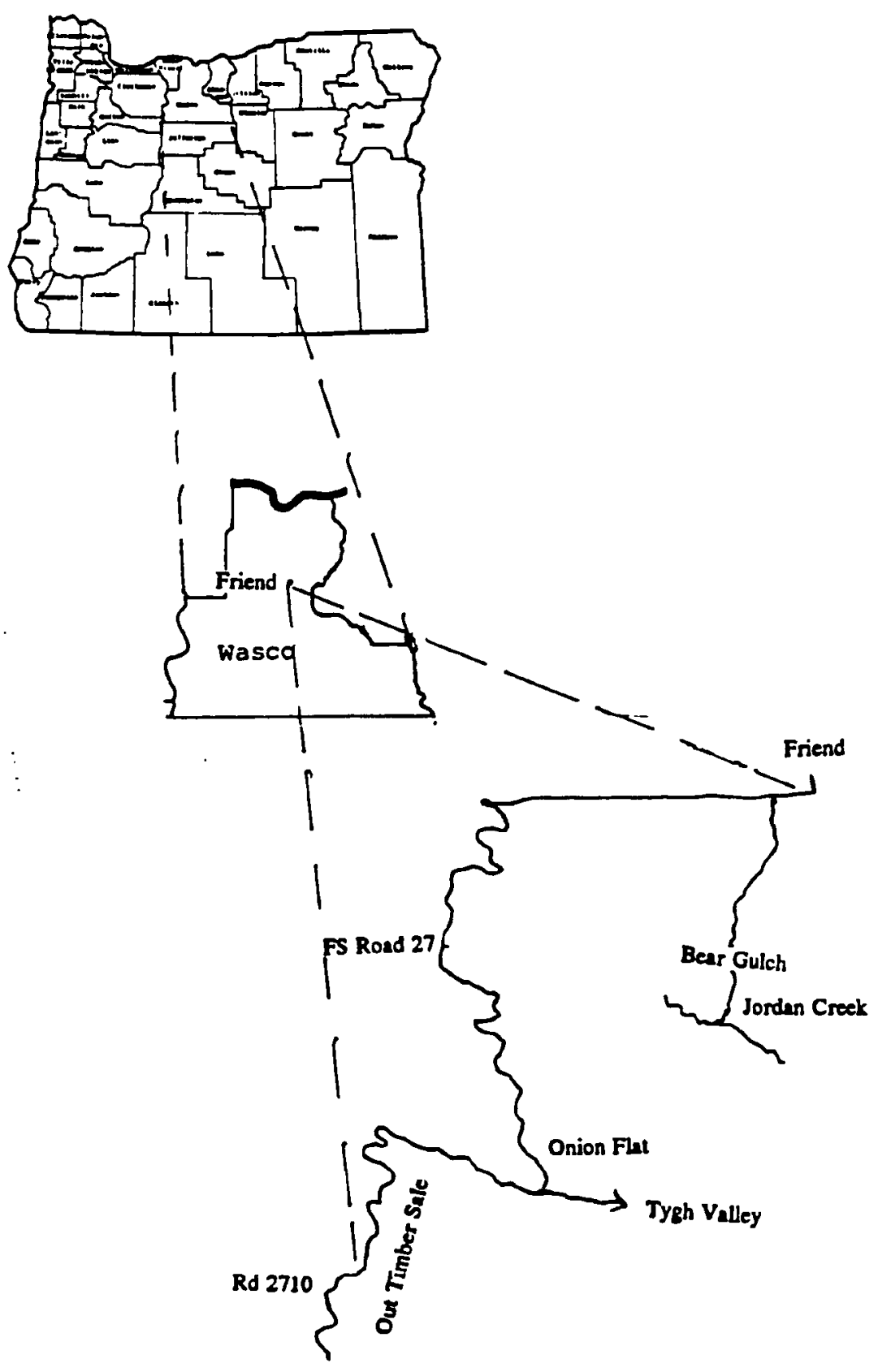

Figure 1. Study area. 
Bear Gulch-Jordan Creek is located in sections 10 and 15 of T3S, R12E. At this site, water is available throughout the year from Jordan Creek and from a seasonal creek in Bear Gulch. Trees are primarily ponderosa pine and Oregon white oak, with occasional Douglas-fir. Conifers have been thinned to promote increased forage for large mammals, and the lands are managed to provide a sustained yield of merchantable timber (L. Cooper, Manager, White River Game Management Area, personal communication, October 19, 1991).

Onion Flats is located on the North-South Road (FS 25) in sections 19 and 20 of T3S, R12E. This area is located next to a timber harvest mitigation pond that provides a year-round source of water. Trees are primarily ponderosa pine and Oregon white oak with occasional Douglas-fir and eastern hemlock. This area was logged in the early 1970s.

Out Timber Sale is located in sections 25, 26, 35 and 36 of T3S, R11E. Water is available from two mitigation ponds, two springs and Badger Creek. The vegetation type is similar to that of the other two major study areas but includes more Douglas-fir. Out Timber Sale, sold in 1976, had not been logged when this study started in 1981, but it was logged from the spring of 1985 through 1990.

A feeding station was maintained in the study area at Friend, Oregon (section 35 of T2S, R12E), for the duration of the study in a grove of ponderosa pine in order to observe behaviors of wild squirrels and released orphaned squirrels. Two large old Oregon white oaks were also in the observation area. The site, located on private land, was off limits to hunting; consequently, it provided a safe site for the 
reintroduction of hand-raised squirrels into a relatively natural area occasionally occupied by wild squirrels. Water was available in a pan below a hand pump. 


\section{CHAPTER IV \\ METHODS AND MATERIALS}

\section{FOOD HABITS}

Hunters were asked to place unused parts of the squirrels in bags and to write on a tag information concerning the date, location where squirrel was shot, time of day the squirrel was shot, the sex of the squirrel and whether or not there were ear tags on the squirrel (see Appendix A). When ear tags were present, the numbers of thnse tags were requested. If any of the squirrels wore radio collars, it was requested that these also be returned (Appendix A).

Seven drop boxes were located along the major access roads used by hunters. Notices of the study were posted at stores and crossroads throughout the general area (Appendix A). Hunters were personally contacted during the first 2 weeks of the season by personnel of the Dalles office of the Oregon Department of Fish and Wildlife, by Oregon State Police game officers, and by me. Articles were included in both the local and statewide newspapers. Drop locations were checked each day during the beginning of the season and during the weekends throughout the season. Response was variable, and not all parts requested were always obtained (Appendix B). 
Observations of feeding habits and partial analysis of contents of stomachs collected from the Hunter Cooperation Program of 1981-1987 provided information on the squirrels' diets. Stomachs were separated from the rest of the viscera collected and placed in $10 \%$ formalin until they could be examined to ascertain the content of starchy material, fungal spores, insect parts and other identifiable materials. Specifically identified materials other than fungal spores will not be reported in this study. Zane Maser of the Forest Research Lab in Corvallis, Oregon, provided the methodology, instruction, and identification of fungal spores by percentage and type in a sample of the stomachs of the squirrels.

\section{LIVE TRAPPING}

Populations of western gray squirrels were initially censured by observation of marked individuals from live trapping. Animals were live trapped throughout the year except during the hunting season from late August through early November. Numbers, densities, sex ratios, reproductive activity, and age structure of the population were determined and monitored with the help of a Hunter Cooperation Program begun in the fall 1981 hunting season and continued for each hunting season through 1987. Quantitative information was gathered on home range by radio telemetry and correlated with observations from live trapping.

The traps used in this study were Tomahawk traps of two sizes. One was $26 \times 9 \times 9$ in.; the other was $32 \times 10 \times 12$ in. Traps were placed where there was evidence of squirrel activity such as sightings, nest sites, and cone cuttings. One trap was set 
at each promising location. Bait consisted of whole kernel corn, cracked and whole walnuts, filberts and other nuts as available. Trap grids were not utilized because of the inherent limitation caused by trap interference with movements, lack of personnel to accomplish the task, and the relatively large home ranges utilized by western gray squirrels (Cross, 1969). The trap pattern in each area was roughly a transect through the area, but distances between traps varied. Traps were checked in the morning and evening. Trapping was conducted at Bear Gulch and Jordan Creek sites during all seasons of the year. In the Out Timber Sale area, Onion Flats, and the area between Badger Creek and Little Badger Creek, trapping was irregular throughout the study from October 1981 through August 1986.

Each squirrel trapped was marked with ear tags. Number one wing bands from National Band and Tag Co. were used. A tag was applied to each ear. The squirrel was released from the trap into a fishnet drawstring bag sewn from $3 / 4$-in. mesh. The bag facilitated handling the squirrel and allowed for efficient weighing, ear tagging, and measurement of tail, head and body, ear, and hind foot (E. R. Hall, 1981). The squirrel's sex, reproductive condition, and general condition were noted. Squirrels were weighed on an Ohaus model 8014 spring scale, measured with a Dean plastic centimeter/inch tape, and then released.

\section{HOME RANGE}

Radiotelemetry and trap data were used to determine home range of selected squirrels in the Bear Gulch/Jordan Creek and Out Timber Sale sites. Six adjustable 
radio collars (MP 14-40), a Yagi folding directional antennae (YA4-1), and a six channel receiver (DTR-6) from Wildlife Materials, Inc. were used. Animals were released from the live traps into a 3/4-in. mesh fishnet bag. A 1:1 dilution of sterile water and Ketamine (hydrochloride) from Parke-Davis Company was injected intramuscularly into each squirrel. The dose was based on weight (Donald Crimmins, DVM, personal communication, September 1981). Squirrels were conscious during the placing of the collar although slowed in their movements. After the collar was in place, each squirrel was placed back into the live trap and covered with a coat or dark cloth until the animal appeared to have recovered sufficiently to be able to run and climb normally. This usually required 1.5 to 2 hours from the time of injection. The collared squirrel was then released. Squirrels were not followed and located until 2 hours after release. Monitoring of locations of squirrels occurred at different times of the day for each radio-collared squirrel as long as the squirrel was collared. Squirrels were specifically located and mapped. Triangulation was not used, as each squirrel was located in a specific tree which was flagged. A 15T Ranger Silva compass and binoculars were used to locate and observe each squirrel. Location points were mapped with reference to the capture site. Radiotelemetry data were used to generate home ranges with the help of AUTO-CAD software.

\section{AGE DETERMINATION}

Squirrels were assigned to relative age classes using the skulls, eye lenses and forearms of the squirrels collected from the Hunter Cooperation Program from August 
1981 to November 1987. Skulls were partially cleaned, left to dry, and later cleaned thoroughly. Relative age classes were based on the following criteria:

1. Juveniles: Until $\mathbf{M}^{3}$ and $\mathrm{m}_{3}$ are at occlusal level, or 3 to 5 months.

2. Subadults: $\mathbf{M}^{3}$ and $m_{3}$ are at occlusal level, but $P^{4}$ and $p_{4}$ are not at occlusal level, or 5 to $15-18$ months;

3. Adults: All permanent teeth in and at occlusal level, enamel wear minimal, or 18 months to 3 or 4 years.

4. Old adults: Significant wear obvious on surface of molars, dentine is obvious and fully visible, older than 3 to 4 years (Forbes, 1966; Nichols, 1958)

The bones of the forearms were scraped clean by hand and left to dry. They were later $x$-rayed using Ektaspeed film 15 ma-90 KVP x-ray film in the Dental Clinic at Mt. Hood Community College. These $\mathrm{x}$-rays were later examined for the presence or absence of the epiphyseal cartilage.

The eye lenses were fixed in $10 \%$ formalin then dried at $80^{\circ} \mathrm{C}$ for 36 to 48 hours in glass vials plugged with cotton. When dried, they were removed and immediately weighed on a Mettler balance to the nearest $0.0001 \mathrm{~g}$. Each lens was weighed separately and weights recorded. The stomachs were separated from the rest of the viscera and preserved in formalin for later study.

The reproductive condition of each animal was noted,and the reproductive tracts of the females and the testes of the males isolated and preserved in formalin for a future study. Tails were to be used in developing a field method for aging squirrels. 


\section{HABITAT REQUIREMENTS}

Twenty-two nest tree sites and three non-nest tree sites were analyzed. Sites were chosen to represent a wide range of conditions under which squirrels' nests were found on private land, U.S. Forest Service land, and Oregon Department of Fish and Wildlife land. Nest trees were analyzed to ascertain the factors that affect the sites at which nests were built. Analysis of nest trees included a one-fifth acre fixed area circular plot with the nest tree at its center. The radius of the plot was $52.7 \mathrm{ft}$ $(16.06 \mathrm{~m})$ (see Figure 2). Diameter of the tree at breast height $(\mathrm{DBH})$, species, and crown class were recorded for each tree in the plot. The categories of crown class used were (Daniel, Helms \& Baker, 1979):

1. $\mathrm{D}=$ dominant tree within the plot

2. $\mathrm{CO}=$ codominant trees within the plot

3. $I=$ intermediate trees within the plot

4. $S=$ suppressed trees within the plot (those that will probably die before reaching maturity or be thinned)

5. $\mathrm{OG}=$ open grown (the canopy of the tree does not touch the canopy of any of the surrounding trees in the plot).

Height of the nest tree, height of the nest, and age of the nest tree were also measured. Four variable plots were measured with a five-gauge prism. These plots were at the four cardinal compass points, $100 \mathrm{ft}(30.48 \mathrm{~m})$ from the nest tree. In addition to the above measurements, each tree within the fixed area plot (FAP) was also mapped with compass, clinometer, and tape measure to generate a map of each 
KEY:

$$
\begin{aligned}
+ & =\text { Nest Tree } \\
\bigcirc & =\text { PIPO } \\
\triangle & =\text { OUGA } \\
\square & =\text { PSME } \\
\square & =\text { ABCO } \\
* & =\text { ALIN }
\end{aligned}
$$

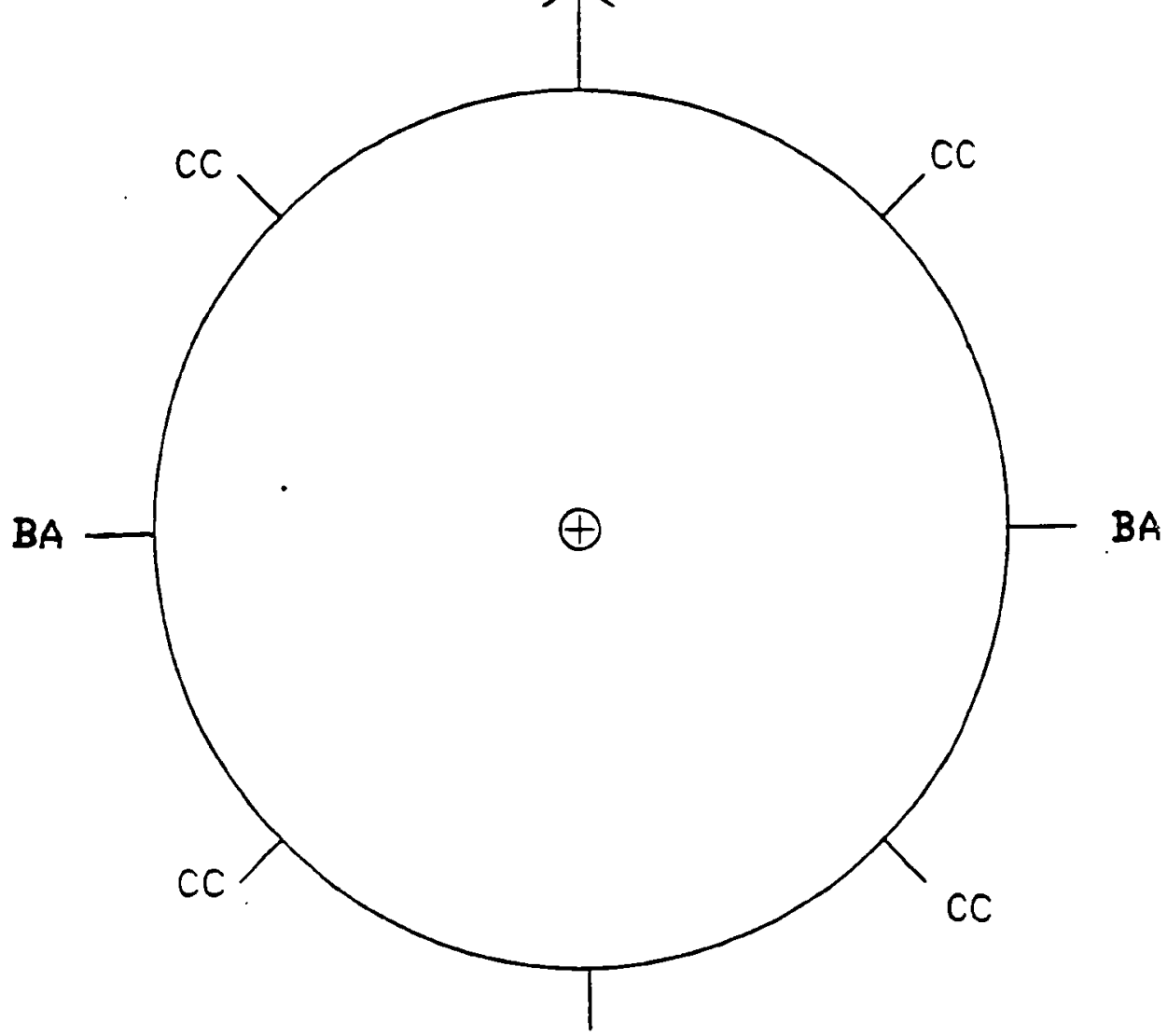

BA

Figure 2. Site measurements of nest tree sites. Note: PIPO = ponderosa pine; QUGA = Oregon white oak; PSME = Douglas-fir; $A B C O=$ Grand fir; ALIN = mountain alder; $\mathrm{CC}=\%$ canopy closure; and $\mathrm{BA}=$ basal area. 
nest tree site. The frequency of vegetation types was measured in terms of percentage frequency in the following categories within the FAP:

1. Percentage mature tree cover (TREEM-trees over $12^{\prime}$ in height).

2. Percentage immature tree cover (TREER-those trees under 12')

3. Percentage tall shrub (SHRBT)

4. Percentage low shrub (SHRBL)

5. Percentage rock and percentage exposed bed rock (ROCK)

6. Percentage herb and moss covered rock (HERB) duff depth (DUFF).

Duff depth is related to the presence of hypogeous and epigeous fungi which constitute a significant portion of the squirrel's diet at certain times of the year (Stienecker, 1977; Stienecker \& Browning, 1970). Distance to water (DIST) was either measured or extrapolated from a map. Within each of the quadrants formed by the four cardinal compass directions, the percentage canopy cover was estimated to the nearest $5 \%$. The quadrants were measured from northeast, southeast, southwest, and northwest.

The range and mean of the various factors considered for each nest tree site were calculated. Other statistical methods were not used, as the sites were not chosen at random but were chosen to present the widest range of variables found during an initial survey of 60 nest tree sites. Non-nest tree sites were also chosen as representative of those areas left for wildlife following timber harvest. 


\section{CHAPTER V}

\section{RESULTS}

\section{FOOD HABITS}

Stomachs of 14 squirrels obtained through the Hunter Cooperation Program between 1981 and 1984 were analyzed for fungal and starchy material. Analysis was done in the winter of 1985 . Fungal spores were identified to genus. The category "starchy material" was used to represent all other food types such as residue from pine seeds, acoms, and so on. The analysis was done by Zane Maser at the Forest Research Laboratory in Corvallis, Oregon, and by me (see Table I).

The fungal spores present in the stomachs represented both hypogeous and epigeous fungi. Observations of squirrels' activities from April 1981 through September 1989 included numerous records of squirrels digging in the ground to obtain the fruiting bodies of hypogeous fungi. This activity occurred from spring through fall of each year. Squirreıs were also observed picking, eating and storing the fruiting bodies of epigeous fungi. These fungi were not identified to species.

Squirrels were also observed cutting green ponderosa pine cones in the late summer and fall of each year. The terminal portion of the branch containing cones was cut as were individual cones. The individual bracts of the cones were then 
TABLE I

STOMACH CONTENT ANALYSIS OF 14 WESTERN GRAY SQUIRRELS, 1981-1984

\begin{tabular}{|c|c|c|c|c|c|c|}
\hline WGS & Date & $\mathrm{Age}^{\mathrm{b}}$ & Sex & Location & Content $^{c}$ & $\mathrm{ID}^{\mathrm{d}}$ \\
\hline 004 & $8 / 29 / 81$ & $A D$ & $\mathbf{F}$ & Rock Creek & $\begin{array}{l}\text { Elaphomyces } 5 \% \\
\text { Octavianina T } \\
\text { Tuber rufum T-1\% } \\
\text { Pollen grain } \\
\text { Starchy material } 94 \%\end{array}$ & ZM \\
\hline 056 & $9 / 6 / 81$ & $\mathrm{AD}$ & $\mathbf{F}$ & $\begin{array}{l}\text { School House } \\
\text { Ridge }\end{array}$ & $\begin{array}{l}\text { Rhizopogon } 40 \% \\
\text { Epigeous spore } 50 \% \\
\text { (Gastroboletus type) } \\
\text { Genea T }\end{array}$ & $\mathrm{ZM}$ \\
\hline 067 & $9 / 12 / 91$ & OA & $\mathbf{F}$ & Badger Creek & $\begin{array}{l}\text { Genea 3\% } \\
\text { Starchy material } 97 \%\end{array}$ & SF \\
\hline 103 & $10 / 11 / 81$ & $A D$ & $F$ & White River & $\begin{array}{l}\text { Rhizopogon } \mathrm{T} \\
\text { Starchy material } 100 \%\end{array}$ & $\mathbf{Z M}$ \\
\hline 106 & $11 / 3 / 81$ & - & $\mathbf{M}$ & $\begin{array}{l}\text { Bonney } \\
\text { Crossing }\end{array}$ & $\begin{array}{l}\text { Rhizopogon } 85-87 \% \\
\text { Geopora } 8-10 \% \\
\text { Starchy material } 5 \%\end{array}$ & SF \\
\hline 112 & $8 / 29 / 82$ & $\mathrm{AD}$ & $\mathbf{M}$ & Tygh Ranch & $\begin{array}{l}\text { Rhizopogon T } \\
\text { Starchy material } 100 \%\end{array}$ & $\mathrm{ZM}$ \\
\hline 115 & $8 / 29 / 82$ & $\mathrm{AD}$ & $\mathbf{F}$ & Badger Lake & $\begin{array}{l}\text { Rhizopogon } \mathrm{T} \\
\text { Elaphomyces } 5 \% \\
\text { Leucogaster T } \\
\text { Gautieria T } \\
\text { Starchy material } 95 \%\end{array}$ & SF \\
\hline 156 & $9 / 12 / 82$ & OA & $\mathbf{M}$ & Little Badger & $\begin{array}{l}\text { Total fungi } 0 \% \\
\text { Starchy material } 100 \%\end{array}$ & $\mathrm{ZM}$ \\
\hline 213 & $10 / 30 / 82$ & $\mathrm{AD}$ & $\mathbf{M}$ & Happy Ridge & $\begin{array}{l}\text { Rhizopogon } 2 \% \\
\text { Starchy material } 98 \%\end{array}$ & $\mathrm{ZM}$ \\
\hline 237 & $9 / 3 / 83$ & $A D$ & $\mathbf{M}$ & Rock Creek & $\begin{array}{l}\text { Rhizopogon } 71 \% \\
\text { Tuber rufum } 10 \% \\
\text { Balsamia or } \\
\text { Geopora } 9 \% \\
\text { Genea T } \\
\text { Epigeous (2 spp.) T }\end{array}$ & $\mathbf{Z M}$ \\
\hline
\end{tabular}


TABLE I

STOMACH CONTENT ANALYSIS OF 14 WESTERN GRAY SQUIRRELS, 1981-1984 (continued)

\begin{tabular}{|c|c|c|c|c|c|c|}
\hline WGS & Date & Age/: & & Location & Content & ID \\
\hline 341 & $10 / 16 / 83$ & - & $\mathbf{F}$ & Jordan Creek & $\begin{array}{l}\text { Rhizopogon } 65 \% \\
\text { Corinarius or related } \\
\text { genera 3\% } \\
\text { Geopora 3\% } \\
\text { Epigeous spore T }\end{array}$ & $\mathbf{Z M}$ \\
\hline 354 & $11 / 1 / 83$ & $\mathrm{AD}$ & $\mathbf{F}$ & Happy Ridge & $\begin{array}{l}\text { Rhizopogon } \mathrm{T} \\
\text { Starchy material } 100 \%\end{array}$ & $\mathrm{ZM}$ \\
\hline 363 & $9 / 1 / 84$ & $\mathrm{AD}^{\mathrm{e}}$ & $\mathbf{F}$ & Tygh Ranch & $\begin{array}{l}\text { Total fungi } 0 \% \\
\text { Starchy material } 100 \%\end{array}$ & $\mathbf{Z M}$ \\
\hline 410 & $10 / 5 / 84$ & $A D$ & $\mathbf{F}$ & Badger Creek & $\begin{array}{l}\text { Tuber rufum 1\% } \\
\text { (in ascus) } \\
\text { Starchy material } 99 \% \\
\text { Pollen grain (2) }\end{array}$ & $\mathrm{ZM}$ \\
\hline
\end{tabular}

'Western gray squirrel Hunter Cooperation Program identification number.

${ }^{\mathrm{b}} \mathrm{AD}=$ adult; $\mathrm{OA}=$ old adult.

G $=$ trace.

${ }^{\mathrm{d}} \mathrm{ID}=$ Identification by; ZM = Zane Maser; SF = Susan Foster.

'Lactating female.

removed and the seeds eaten. Acorns from Oregon white oak were eaten in the diet primarily during the winter and early spring.

Additional foods taken included nectar from honeysuckle (Lonicera coliosa) and the foliage of miner's lettuce (Montia perforiata). Both of these were eaten between late spring and midsummer.

At a feeding station located in the study site at Friend, various commercially available nuts such as English walnut, black walnut, hazelnut, pecans, almonds, 
pistachios and peanuts were offered. Squirrels showed a preference for all these nuts over sunflower seeds, with a particular preference for pistachios as indicated by the order in which they fed on the nuts. Quantitative measurements of preference were not recorded. Squirrels buried these nuts, as well as acorns, singly.

\section{SIZE}

Data on body size, tail length and weight were obtained from 17 male and 36 female squirrels captured in live traps. Although the body size of the males was significantly greater than that of the females, there was no significant difference between the sexes in tail lengths. Weights were similar for both sexes unless females were pregnant. Pregnant females were heavier than other squirrels (Table II). Relative age of live-trapped squirrels could not be accurately ascertained.

\section{REPRODUCTION AND GROWTH}

Live-trapped female squirrels displayed periods of estrous and pregnancy from January through March and lactation from April through July (Table III). Nonbreeding females were trapped in the spring (March 1982, 1984 and 1985), in the fall (August 1983 and 1984), and in the winter (November 1984, December 1982 and January 1983).

Live-trapped males exhibited scrotal testes (breeding condition) in the spring (March 1982, 1984 and 1985), in the summer (June 1984), and in the winter (November 1984, December 1982, and January 1983) as shown in Table IV. Males 
TABLE II

SIZE OF LIVE-TRAPPED SQUIRRELS

\begin{tabular}{lll}
\hline & $\begin{array}{c}\text { Females } \\
\frac{\mathrm{x} \pm 2 \text { SE }}{\text { Range }}(\mathrm{n})\end{array}$ & $\begin{array}{c}\text { Males } \\
\frac{\bar{x} \pm 2 \text { SE }}{\text { Range }}(\mathrm{n})\end{array}$ \\
\hline Body length & $\frac{307 \pm 2}{27-35}(36)$ & $\frac{329 \pm 19}{27-39}(17)$ \\
Tail length & $\frac{313 \pm 1}{24-38}(36)$ & $\frac{318 \pm 20}{24-38}(17)$ \\
Weight & $\frac{781 \pm 31.5}{500-950}(36)$ & $\frac{806 \pm 55.6}{525-925}(17)$ \\
\hline
\end{tabular}

Note. Linear measurements are in milimeters; weights are in grams.

appeared to be in a breeding state in the winter (November through January) and in the spring (March through June). These periods coincided with the peak breeding periods of the females.

Data from the Hunter Cooperation Program showed lactating females present as late as mid-October each year from 1981 to 1986 . No lactating females were found in the sample from 1987. Three females classified as lactating had nipples which did not produce milk when squeezed, but were greatly enlarged indicating recent nursing by young (see Table V). 
TABLE III

DATA ON REPRODUCTIVE STATUS OF

LIVE-TRAPPED FEMALE SQUIRRELS

\begin{tabular}{llllllll}
\hline \multicolumn{2}{c}{ Non-breeding } & \multicolumn{2}{c}{ Estrous } & \multicolumn{2}{c}{ Pregnant } & \multicolumn{3}{c}{ Lactating } \\
\multicolumn{1}{c}{ Date } & $\#$ & \multicolumn{1}{c}{ Date } & $\#$ & \multicolumn{1}{c}{ Date } & $\#$ & Date & $\#$ \\
\hline March 1982 & 3 & Feb. 1982 & 1 & March 1982 & 3 & Apr. 1982 & 1 \\
Dec. 1982 & 1 & March 1982 & 1 & Jan. 1983 & 1 & May 1982 & 1 \\
Jan. 1983 & 1 & Jan. 1983 & 1 & Feb. 1983 & 1 & July 1983 & 2 \\
Aug. 1983 & 2 & & & Feb. 1984 & 2 & & \\
March 1984 & 2 & & & & & & \\
Aug. 1984 & 1 & & & & & & \\
Nov. 1984 & 2 & & & & & & \\
March 1985 & 1 & & & & & & \\
\multicolumn{1}{c}{ Total } & 13 & & 3 & & 7 & & 4 \\
\hline
\end{tabular}

Three female squirrels trapped repeatedly were initially non-breeding, then in succeeding trapping periods were in estrous, pregnant and lactating. These females showed weight gains of $130-250 \mathrm{~g}$.

Young squirrels weighing $500 \mathrm{~g}$ or less could not be used in home range studies, as their head and neck circumferences were so similar that a radio collar could not be securely attached to them. All of the young squirrels I observed weighed about $500 \mathrm{~g}$. Observation of hand-raised squirrels indicated that head sizes increased to adult proportions at approximately 18 months of age. Young squirrels were also observed to have more white on the hair at the ends of the tails, and they carried their 
TABLE IV

DATA ON REPRODUCTIVE STATUS OF

LIVE-TRAPPED MALE SQUIRRELS

\begin{tabular}{llll}
\hline \multicolumn{2}{c}{ Non-breeding } & \multicolumn{2}{c}{ Scrotal (breeding) } \\
\hline March 1982 & 4 & March 1982 & 2 \\
May 1982 & 1 & Dec. 1982 & 1 \\
Dec. 1982 & 1 & Jan. 1983 & 3 \\
Feb. 1983 & 4 & March 1984 & 4 \\
March 1983 & 5 & June 1984 & 2 \\
June 1983 & 3 & Nov. 1984 & 1 \\
Nov. 1983 & 3 & March 1985 & 1 \\
Jan. 1984 & 1 & & \\
Feb. 1984 & 2 & & \\
Apr. 1985 & 2 & & \\
Total & 26 & Total & 14 \\
\hline
\end{tabular}

heads at a higher angle than adults. I did not quantify these observations which were made over 7 years of field research. The only reliable method for distinguishing sex in free-ranging squirrels is to observe evidence of nipples or external genitalia, which are visible at a distance due to color differences. Both appear dark on the white underside of the squirrels. 
TABLE V

DATA ON LACTATING FEMALE SQUIRRELS TAKEN IN THE HUNTER COOPERATION PROGRAM, AUGUST-NOVEMBER, 1981-1987

\begin{tabular}{|c|c|c|}
\hline Year/day & Age" & HCP \# \\
\hline \multicolumn{3}{|l|}{1981} \\
\hline 31 August & $\mathrm{AD}$ & 029 \\
\hline 26 August & $\mathrm{AD}$ & 030 \\
\hline \multicolumn{3}{|l|}{1982} \\
\hline 29 August & $\mathrm{AD}$ & 120 \\
\hline 29 August & $\mathrm{OA}$ & 124 \\
\hline 31 August & OA & 128 \\
\hline 28 August & $\mathrm{OA}$ & 133 \\
\hline 2 September & $\mathrm{AD}$ & 134 \\
\hline 4 September & $\mathrm{AD}$ & 137 \\
\hline 8 September & $\mathrm{AD}$ & 144 \\
\hline 10 September & OA & 149 \\
\hline 12 September & SA & 158 \\
\hline 2 September & SA & 178 \\
\hline 14 October & $\mathrm{AD}$ & 197 \\
\hline 26 September & $\mathrm{AD}$ & 184 \\
\hline
\end{tabular}


TABLE V

DATA ON LACTATING FEMALE SQUIRRELS TAKEN IN THE HUNTER COOPERATION PROGRAM, AUGUST-NOVEMBER, 1981-1987

(continued)

\begin{tabular}{|c|c|c|}
\hline Year/day & Age & $\mathrm{HCP}$ \\
\hline \multicolumn{3}{|l|}{1983} \\
\hline 4 September & $A D$ & 269 \\
\hline 13 September & $A D$ & $325^{\mathrm{c}}$ \\
\hline 13 September & $\mathrm{AD}$ & 328 \\
\hline 13 September & -- & 336 \\
\hline 7 July & $A D$ & 350 \\
\hline \multicolumn{3}{|l|}{1984} \\
\hline 1 September & $\mathrm{AD}$ & 362 \\
\hline 3 September & $\mathrm{AD}$ & 373 \\
\hline 3 September & $A D$ & 379 \\
\hline 3 September & $A D$ & 380 \\
\hline 4 September & $\mathrm{AD}$ & 383 \\
\hline 13 September & $\mathrm{AD}$ & 395 \\
\hline 13 September & $\mathrm{OA}$ & 396 \\
\hline 8 September & $A D$ & 407 \\
\hline
\end{tabular}


TABLE V

DATA ON LACTATING FEMALE SQUIRRELS TAKEN IN THE HUNTER COOPERATION PROGRAM,

AUGUST-NOVEMBER, 1981-1987

(continued)

\begin{tabular}{ccc}
\hline Year/day & Age $^{A}$ & HCP \\
\hline 1985 & & \\
1 September & AD & 446 \\
1 September & AD & 447 \\
1 September & AD & 448 \\
1 September & - & 450 \\
2 September & OA & 460 \\
8 September & AD & 468 \\
12 September & OA & $472^{d}$ \\
1986 & & \\
30 August & & \\
6 September & AD & 584 \\
None & & \\
\hline
\end{tabular}

SA = Subadult, $A D=$ Adult, $O A=$ Older adult.

'Western gray squirrel Hunter Cooperation Program identification number.

${ }^{\circ}$ Ear tag 38/39.

Indicates cessation of lactation. 


\section{LIVE-TRAPPING RESULTS}

Seventy-nine squirrels were live trapped in seasonal trap sessions from November 1981 through April 1988 (see Table VI). Of the 77 on which data were taken, 16 were multiple captures as shown by the ear tags. Nine of these animals were trapped twice, two were trapped three times, four were trapped four times and one was trapped five times (see Table VII). Two of the live-trapped squirrels were not included in the study, as insufficient data were available on them. Trapping sessions varied in length and consisted of periods when classes were not in session ${ }^{2}$ (see Table VIII).

Five ear-tagged squirrels were returned in the Hunter Cooperation Program during the fall hunting season (see Table VII). Three were obtained in 1983 and one each in 1985 and 1986. Determination of the ages of these five squirrels from their teeth shows that one was a subadult, two were adults and two were old adults.

Fifty-two males and 25 females were trapped (see Table VIII). The most productive trap period of this study was spring with 21 males and 11 females trapped during March-April. November through February was the second most successful trap period with 18 males and 9 females trapped. The summer period of June-August had the least success of the three major trap periods with 13 males and 5 females captured. Trapping was not conducted during the hunting season from late August through the first week of November each year. Trap days per squirrel averaged 21.6

\footnotetext{
${ }^{2} \mathrm{I}$ am a full-time member of the faculty at Mt. Hood Community College.
} 
TABLE VI

RESULTS OF LIVE TRAPPING, 1981-1986

\begin{tabular}{llccc}
\hline Year & Period(s) & Number trapped & Trap days & Trap days/squirrel \\
\hline 1981 & Oct.-Nov. & 2 & 491 & 245.5 \\
1982 & Feb.-May, Dec. & 22 & 273 & 12.4 \\
1983 & $\begin{array}{l}\text { Jan.-Feb. } \\
\text { June-Aug., Nov. }\end{array}$ & 29 & 481 & 16.59 \\
1984 & Jan.-March, Nov. & 18 & 235 & 13.06 \\
1985 & March-April & 4 & 145 & 36.25 \\
1986 & Aug. & 4 & 82 & 20.5 \\
\hline
\end{tabular}

with the inclusion of 1981 when small squirrel traps were used. These traps were

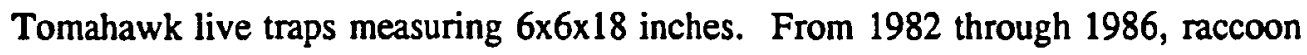
and dog traps were used, and western gray squirrels were more frequently captured. Trap days per squirrel captured dropped to 15.8 . These larger traps were $9 \times 9 \times 24$ in. and $11 \times 11 \times 36$ in. in size, respectively.

The other animals captured most frequently were California ground squirrels (Spermophilus beecheyi) and Steller's jays (Cyanocitta stelleri) (see Table IX), and Douglas' squirrels, and northern flying squirrels (Glaucomys sabrinus) (see Table X). Yellow pine chipmunks (Tamias amoenus) were observed in the larger traps but were able to escape through the mesh of the trap. 
TABLE VII

RECAPTURED WESTERN GRAY SQUIRRELS

\begin{tabular}{llllll}
\hline WGS \# & Date & Sex & $\begin{array}{l}\text { Breeding } \\
\text { Condition }\end{array}$ & Location & Weight \\
$(\mathrm{g})$
\end{tabular}


TABLE VII

RECAPTURED WESTERN GRAY SQUIRRELS

(continued)

\begin{tabular}{|c|c|c|c|c|c|}
\hline WGS \#" & Date & Sex & $\begin{array}{l}\text { Breeding } \\
\text { Condition }^{b}\end{array}$ & Location & $\begin{array}{l}\text { Weight } \\
\text { (g) }\end{array}$ \\
\hline $126 / 127$ & $\begin{array}{l}8 / 14 / 86 \\
8 / 16 / 86 \\
8 / 17 / 86\end{array}$ & $\mathbf{M}$ & $\begin{array}{l}\text { NB } \\
\text { NB } \\
\text { NB }\end{array}$ & Onion Flat & $\begin{array}{l}500 \\
500 \\
500\end{array}$ \\
\hline $30 / 31^{i j}$ & $\begin{array}{l}3 / 28 / 82 \\
4 / 10 / 82 \\
3 / 22 / 84 \\
11 / 23 / 84\end{array}$ & F & $\begin{array}{l}\text { Pregnant } \\
\text { Lactating } \\
\text { Pregnant } \\
\text { NB }\end{array}$ & Bear Gulch & $\begin{array}{l}925 \\
650 \\
780 \\
850\end{array}$ \\
\hline $56 / 57$ & $\begin{array}{l}3 / 22 / 83 \\
6 / 19 / 83 \\
2 / 11 / 84 \\
3 / 20 / 84\end{array}$ & $\mathbf{M}$ & $\begin{array}{l}\text { NB } \\
\text { NB } \\
\text { ST } \\
\text { ST }\end{array}$ & Bear Gulch & $\begin{array}{l}800 \\
850 \\
850 \\
860\end{array}$ \\
\hline كالو 38/3 & $\begin{array}{l}12 / 11 / 82 \\
2 / 27 / 83 \\
3 / 22 / 84 \\
11 / 23 / 84\end{array}$ & F & $\begin{array}{l}\text { NB } \\
\text { Pregnant } \\
-- \\
\text { NB }\end{array}$ & Bear Gulch & $\begin{array}{l}750 \\
900 \\
760 \\
825\end{array}$ \\
\hline $80 / 92$ & $\begin{array}{l}1 / 14 / 84 \\
3 / 20 / 84 \\
11 / 23 / 84 \\
4 / 14 / 85\end{array}$ & $\mathbf{M}$ & $\begin{array}{l}-- \\
\text { ST } \\
\text { NB } \\
\text { NB }\end{array}$ & Bear Gulch & $\begin{array}{l}650 \\
600 \\
750 \\
775\end{array}$ \\
\hline $17 / 18$ & $\begin{array}{l}3 / 15 / 82 \\
3 / 24 / 82 \\
3 / 24 / 82 \\
3 / 25 / 82 \\
5 / 16 / 82\end{array}$ & F & $\begin{array}{l}\text { NB } \\
\text { Estrous } \\
\text { Estrous } \\
\text {-- } \\
\text { Lactating }\end{array}$ & $\begin{array}{l}\text { Bear Gulch } \\
\text { Morning } \\
\text { Evening }\end{array}$ & $\begin{array}{l}800 \\
800 \\
800\end{array}$ \\
\hline
\end{tabular}


TABLE VII

RECAPTURED WESTERN GRAY SQUIRRELS

(continued)

Returned by Hunter Cooperation Program

WGS \# Date tagged Date killed Location

\begin{tabular}{llll}
\hline $81 /$ & $8 / 20 / 83$ & $10 / 9 / 83$ & Out Timber Sale \\
$66 / 89$ & $3 / 22 / 83$ & $10 / 10 / 83$ & Bear Gulch \\
$58 / 49$ & $3 / 24 / 83$ & $10 / 10 / 83$ & Bear Gulch \\
$38 / 39$ & $12 / 11 / 82$ & $10 / 12 / 85$ & Bear Gulch \\
$128 / 129$ & $8 / 17 / 86$ & $8 / 30 / 86$ & Onion Flat \\
\hline
\end{tabular}

"Western Gray Squirrel ear tag numbers.

'ST $=$ Testes in scrotal position. NB $=$ Not in breeding condition.

'Channel V squirrel.

'No collar when recaptured.

'Channel II squirrel.

'Squirrel killed and retumed from Hunter Cooperation Program 10/10/83.

Channel III squirrel.

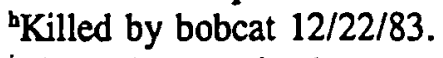

iChannel VI squirrel.

jRemoved collar on $11 / 23 / 84$.

${ }^{k}$ Channel IV squirrel.

'Killed and returned from Hunter Cooperation Program 10/12/85.

mChannel III-2 squirrel.

"Removed collar on $3 / 20 / 84$. 
TABLE VIII

SEX RATIOS AND CAPTURE RATES FOR LIVE-TRAPPED WESTERN GRAY SQUIRRELS

\begin{tabular}{|c|c|c|c|c|}
\hline \multirow[b]{2}{*}{ Month } & \multicolumn{2}{|c|}{ Number } & \multirow[b]{2}{*}{ Trap days } & \multirow[b]{2}{*}{ Trap days/WGS } \\
\hline & Males & Females & & \\
\hline January & 4 & 2 & 62 & 10.3/WGS \\
\hline February & 6 & 4 & 54 & 5.4/WGS \\
\hline March & 17 & 10 & 330 & 12.4/WGS \\
\hline April & 3 & 0 & 67 & 26.5/WGS \\
\hline May & 1 & 1 & 55 & 40.7/WGS \\
\hline June & 5 & 0 & 64 & 20.9/WGS \\
\hline July & 1 & 2 & 113 & 44.6/WGS \\
\hline August & 7 & 3 & 460 & 46.0/WGS \\
\hline September & 0 & 0 & $\mathrm{HS}^{b}$ & \\
\hline October & 0 & 0 & $H S^{b}$ & \\
\hline November & 6 & 2 & 92 & 11.5/WGS \\
\hline December & 2 & 1 & 52 & 11.3/WGS \\
\hline Total & 52 & 25 & & \\
\hline
\end{tabular}

"WGS = Western gray squirrels.

${ }^{\mathrm{b}} \mathrm{HS}=$ Hunting season. 
TABLE IX

MAIN TRAP COMPETITORS, 1981-1986

\begin{tabular}{lccc}
\hline Year & California ground squirrel & Steller's Jay & Other' \\
\hline 1981 & 29 & 112 & 14 \\
1982 & 56 & 27 & 0 \\
1983 & 47 & 1 & 9 \\
1984 & 40 & 4 & 5 \\
1985 & 13 & 0 & 0 \\
1986 & 4 & 0 & 1 \\
\hline
\end{tabular}

'See Table 10 for the list of species included in this category.

Observations of trap sites revealed a high frequency of mule deer, elk and Merriam's turkeys stealing the bait. Douglas' squirrels and California ground squirrels were both observed chasing westem gray squirrels from bait at trap sites. On one occasion both a western gray squirrel and a California ground squirrel were found in the same trap. The westem gray squirrel died from injuries shortly after removal from the trap, while the smaller ground squirrel was unharmed.

\section{HOME RANGE}

From 1983 through 1985, three female and five male western gray squirrels were equipped with radio collars to measure home ranges. The first squirrel was a 
TABLE $\mathrm{X}$

OTHER SPECIES TRAPPED, 1981-1986

\begin{tabular}{lc}
\multicolumn{1}{c}{ Species } & Number trapped \\
\hline Spermophilus beecheyi & 188 \\
Cyanocitta stelleri & 140 \\
Tamiasciurus douglasii & 12 \\
Glaucomys sabrinus & 5 \\
Tamias amoenus & 3 \\
Northern Flicker (Colaptes auratus) & 3 \\
Bushy-tailed woodrat (Neotoma cinerea) & 2 \\
Northern pocket gopher (Thomomys talpoides) & 1 \\
Nuttall cottontail (Sylvilagus nuttallii) & 1 \\
White-breasted nuthatch (Sitta carolinensis) & 1 \\
\hline
\end{tabular}

lactating female collared in the Out Timber Sale in an area on table land between Little Badger Creek to the north and Badger Creek to the south. The squirrel used four nests within her range. No transmissions were received after the week of September 8 during the 1983 hunting season. If the animal was taken by a hunter,the collar was not returned. Her range consisted of flat land in a precommercial thin and a long draw that led towards Little Badger Creek. No other water was located in the home range. Her home range area encompassed 1.68 ha. Two other females tracked 
from March to November 1984 used home ranges of 3.94 and 6.47 ha, respectively (see Table XI).

Two males collared in November 1983 were both tracked for 1 month. The home range of one was 5.09 ha.; that of the other was 2.98 ha. One male tracked from January to March 1984 used a 4.60 ha home range. A second male tracked from February to September 1984 used a 4.86 ha home range.

TABLE XI

HOME RANGES OF EIGHT WESTERN GRAY SQUIRRELS

\begin{tabular}{|c|c|c|c|c|c|}
\hline $\begin{array}{l}\text { Channel } \\
\text { number }\end{array}$ & Sex & Location & Dates & Season(s) & Size \\
\hline 1 & $\mathbf{F}$ & Out Timber Sale & $7 / 9 / 83-9 / 24 / 83$ & Summer/fall & $1.68 \mathrm{ha}$ \\
\hline $2-1$ & $\mathbf{M}$ & Bear Gulch & $11 / 19 / 83-12 / 16 / 83$ & Winter & 5.09 ha \\
\hline $3-1$ & $\mathbf{M}$ & Bear Gulch & $11 / 19 / 83-12 / 18 / 83$ & Winter & 2.98 ha \\
\hline $3-2$ & $\mathbf{M}$ & Bear Gulch & $1 / 15 / 84-3 / 20 / 84$ & Winter & 4.60 ha \\
\hline 5 & $\mathbf{M}$ & Bear Gulch & $2 / 11 / 84-9 / 8 / 84$ & Spring/Summer & 4.86 ha \\
\hline 6 & $\mathbf{F}$ & $\begin{array}{l}\text { Bear Gulch/ } \\
\text { Jordan Creek }\end{array}$ & $3 / 22 / 84-11 / 23 / 84$ & $\begin{array}{l}\text { Spring/Summer/ } \\
\text { Fall }\end{array}$ & $3.94 \mathrm{ha}$ \\
\hline 4 & F & Bear Gulch & $3 / 24 / 84-11 / 23 / 84$ & $\begin{array}{l}\text { Spring/Summer/ } \\
\text { Fall }\end{array}$ & 6.47 ha \\
\hline $2-2$ & $\mathbf{M}$ & $\begin{array}{l}\text { Bear Gulch/ } \\
\text { Jordan Creek }\end{array}$ & $6 / 27 / 84-3 / 25 / 85$ & $\begin{array}{l}\text { Summer/Fall/ } \\
\text { Spring/Winter }\end{array}$ & Linear \\
\hline
\end{tabular}


A third male tracked for 3 months from June to September 1984 had a linear home range within my study area. His primary nest was more than $800 \mathrm{~m}$ from where he was trapped. The nest was located in a tree on the canyon wall on the north slope of Jordan Creek. The signal disappeared within three months, and when the squirrel was recaptured nine months later, he had no collar. His appearance in my study area coincided with the period of estrous for female squirrels.

\section{AGE DETERMINATION}

Age structure data for this population of western gray squirrels was assembled from information collected during the Hunter Cooperation Program from 1981 through 1987 (see Table XII). Not all animals were represented by parts appropriate to determine their age and/or sex. Tooth eruption, replacement of teeth and wear patterns of molars in whole skulls, partial skulls, and lower jaws were examined to separate the animals into four age categories-old adult, subadult, adult, and juvenile (see Table XII and Figure 3). The majority of the animals obtained over the period of the study were adults $(43.5 \% ; \underline{n}=224)$ and subadults $(22.3 \% ; \underline{n}=115)$. Juveniles $(\underline{n}=58)$ and old adults $(\underline{n}=39)$ were least represented at $11.3 \%$ and $7.6 \%$, respectively. The age of $15.3 \%$ of the sample could not be determined (see Table XII).

Two measurements were taken on the whole skulls of squirrels of known age for comparison. The greatest length of skull and the least interorbital breadth 


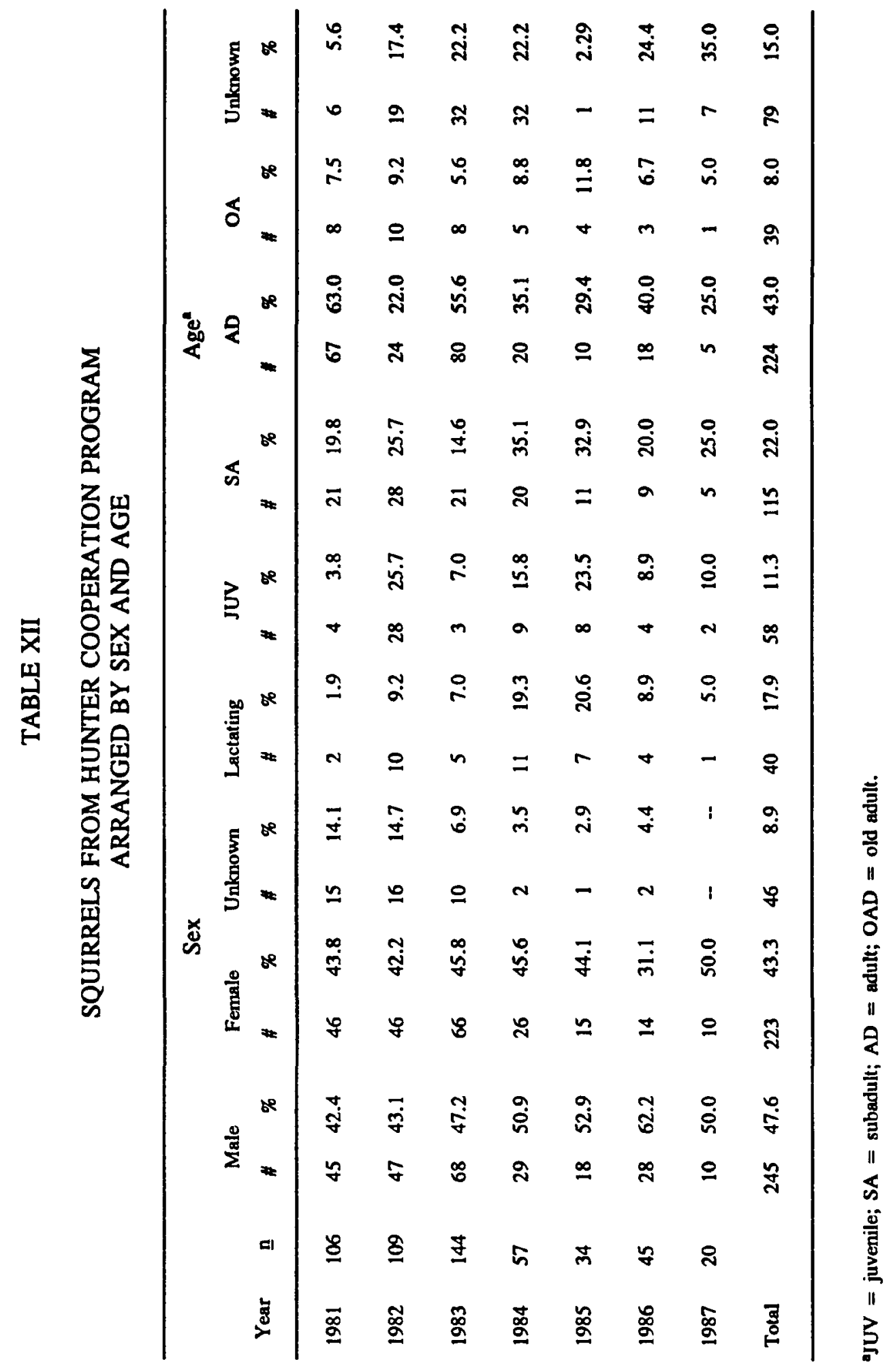




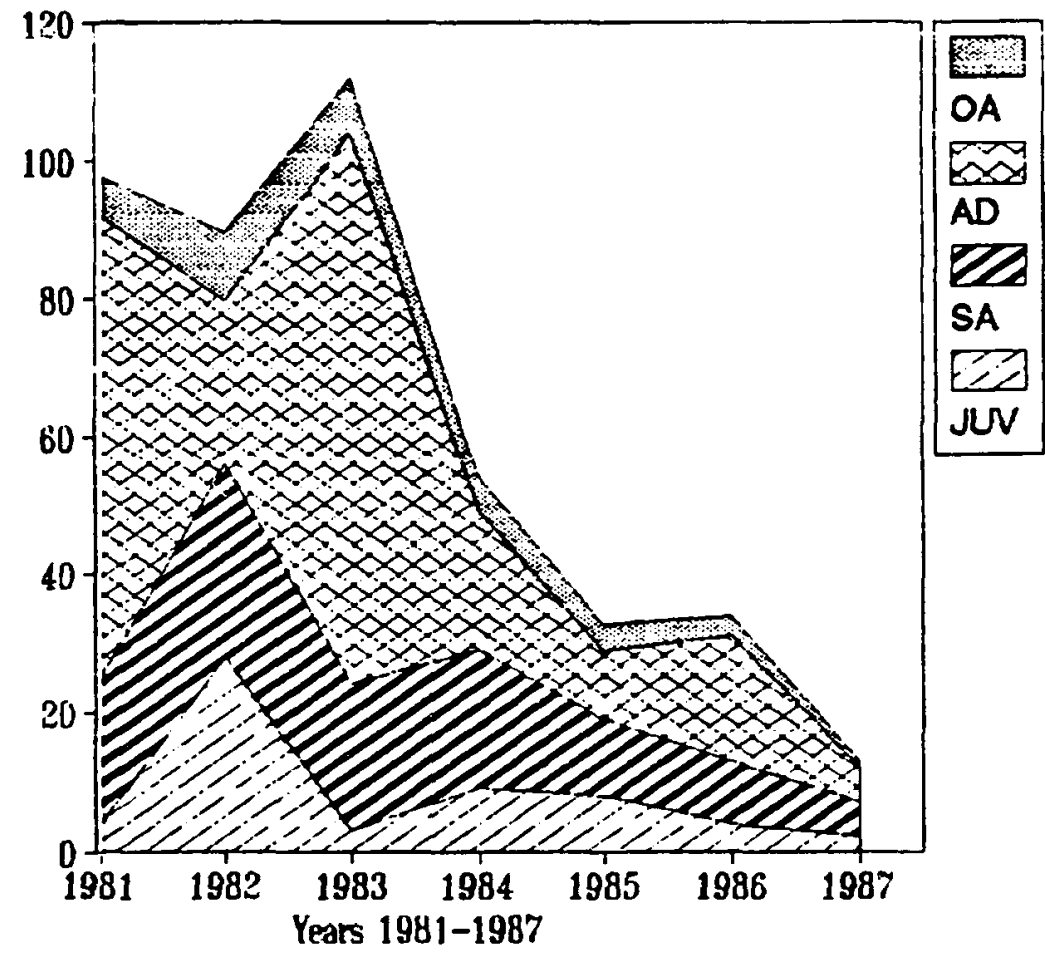

Figure 3. Numbers of squirrels of each age category taken in the Hunter Cooperation Program, 1981-1987. 
characterize the size of a given skull. Each of these measurements showed a positive correlation with age (see Table XIII, Figures 4 and 5).

The sex of a squirrel cannot be determined from its skull. Information concerning the sex of the animals relied on either the presence of gonads in remains or on information retumed by the hunters. Males constituted $47.6 \%$ and females $43.3 \%$ of the total sample. Sex could not be determined for $17.9 \%$ of the sample.

Lactating females comprised $7.8 \%$ of the total sample (see Table XII); 27 of the 37 lactating females in the sample were taken during September (see Table V). Although males with enlarged testes were noted among squirrels taken in the Hunter Cooperation Program, no quantitative evaluation was completed.

\section{NEST TREES}

An initial survey of the study area located 60 nest trees sites on private, federal and state lands. A random sample of these sites did not indicate the wide range of variability of sites in which western gray squirrels nest, so the sample was discarded. Then, 21 of the 60 sites were chosen for analysis because of their variety of tree types, number of trees, size of trees, height of trees and habitats within which they were located. Three non-nest tree sites were also chosen for analysis as representative of the types of trees and sites often left for wildlife use. Statistical analysis of the sites was not possible, as they were not randomly selected. Of the 21 nest tree sites and 3 non-nest tree sites utilized in this study, 14 were located in the White River Game Management Area, and 10 were located within the Barlow Ranger 
TABLE XIII

SKULL MEASUREMENTS OF KNOWN-AGE SQUIRRELS

\begin{tabular}{cccc}
\hline & & Greatest skull length & Least interorbital breadth (mm) \\
$\begin{array}{c}\text { Sample } \\
\text { Size }\end{array}$ & Age & $\frac{\bar{x} \pm 2 \text { SE }(n)}{\text { Range }}$ & $\frac{\bar{x} \pm 2 \text { SE }(n)}{\text { Range }}$ \\
\hline 31 & Older Adult & $\frac{67.9 \pm .44}{65.3-69.7}$ & $\frac{21.4 \pm .22}{20.0-22.9}$ \\
207 & Adult & $\frac{67.3 \pm .16}{64.3-69.9}$ & $\frac{20.8 \pm .12}{18.0-23.1}$ \\
82 & Subadult & $\frac{64.6 \pm .46}{59.6-69.3}$ & $\frac{19.6 \pm .22}{17.5-21.9}$ \\
21 & Juvenile & $\frac{59.7 \pm 1.3}{52.8-65.0}$ & $\frac{17.9 \pm .41}{15.7-21.0}$ \\
\hline
\end{tabular}

District of the Mt. Hood National Forest (see Table XIV). Site analysis was conducted occurred during the summers of 1985 and 1987. Measurements were taken of both site characteristics (see Table XIV) and nest tree characteristics (see Table XV). Comparisons of nest tree sites and non-nest tree sites showed that the components chosen for analysis were sufficient to discriminate between nest trees and non-nest trees $100 \%$ of the time. The most important components of the nest tree sites were high percentage of canopy closure (indicating degree of closeness or relatedness of adjacent trees) and being within $180 \mathrm{~m}$ of water. Nest tree age and diameter at breast height, relative to the nature of the site, appeared to be the most important determinants of the tree chosen. All nest trees noted in the study were 


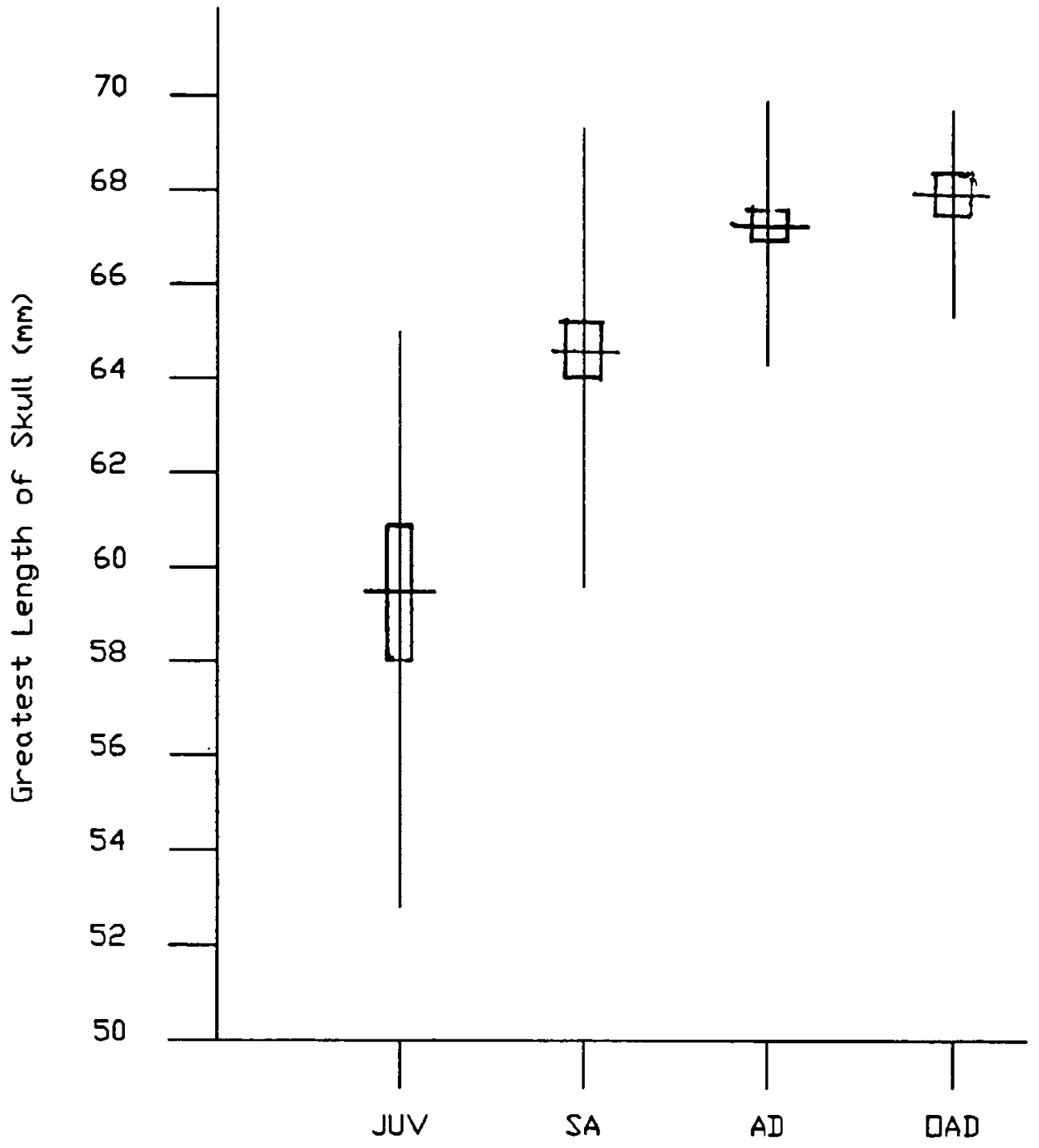

Eigure 4. Mean, standard deviation, and range of greatest skull length of squirrels taken in the Hunter Cooperation Program, 1981-1987. 


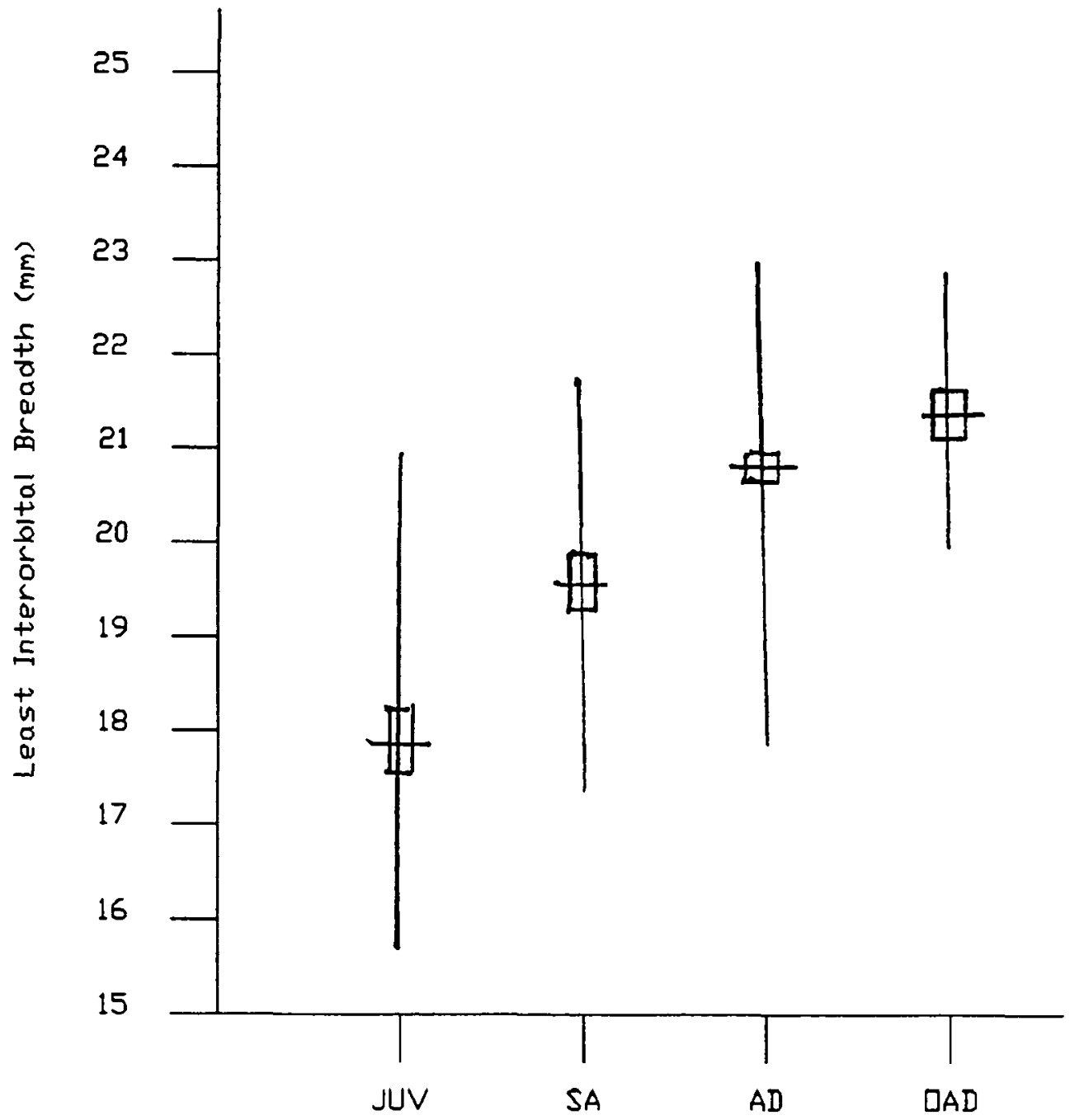

Figure 5. Mean, standard deviation, and range of least interorbital breadth of squirrels by age taken in the Hunter Cooperation Program, 1981-1987. 


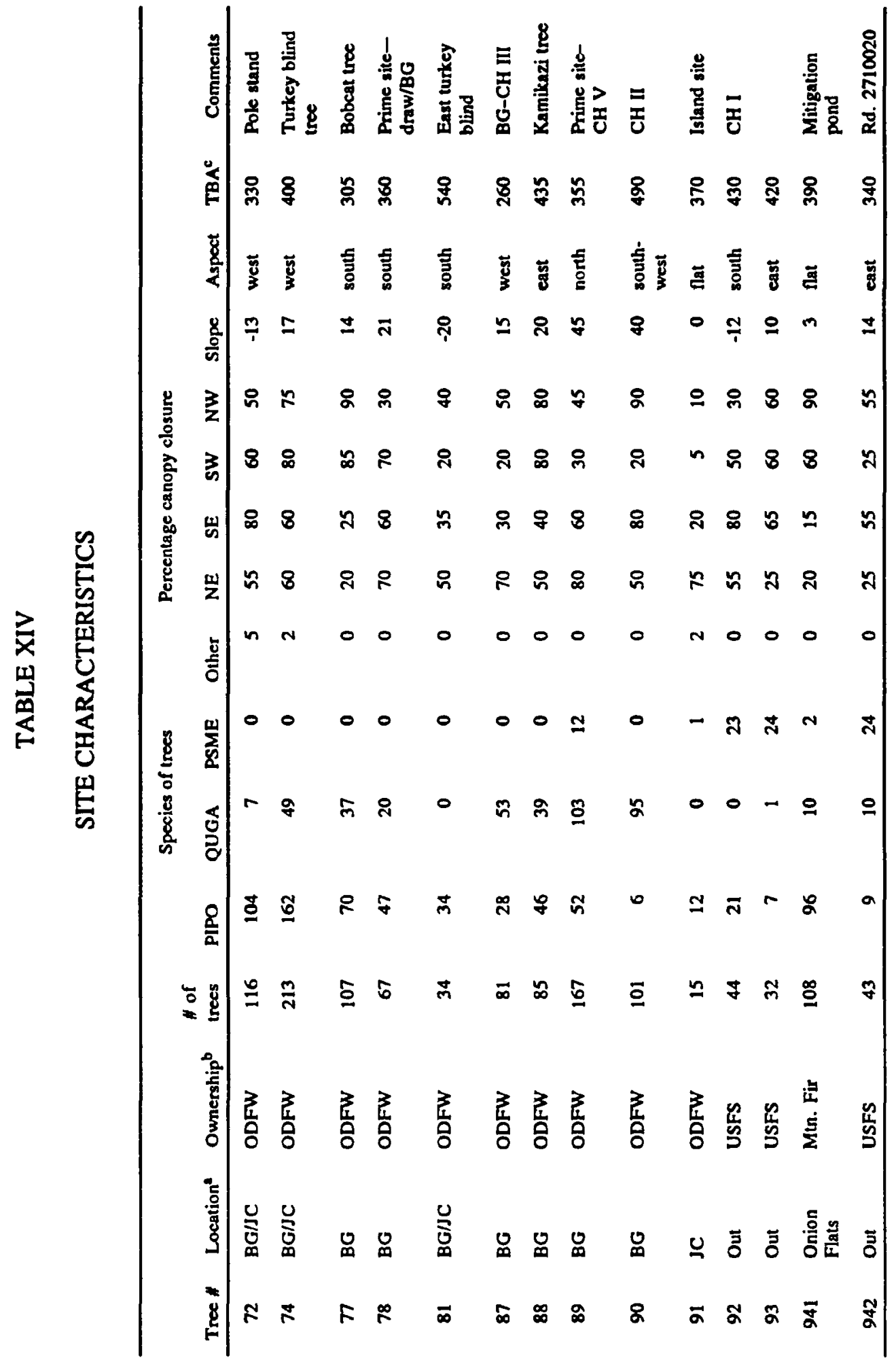




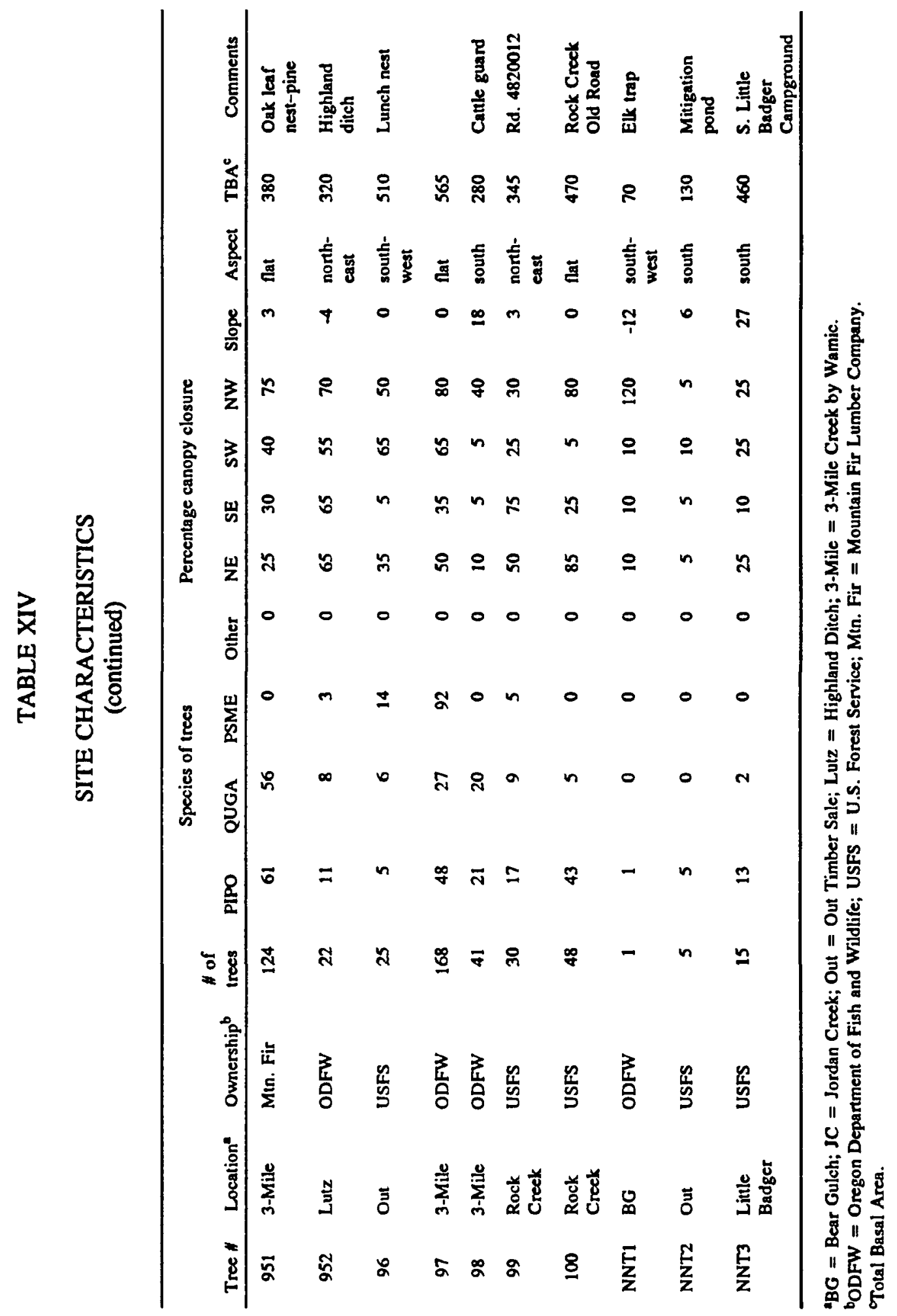




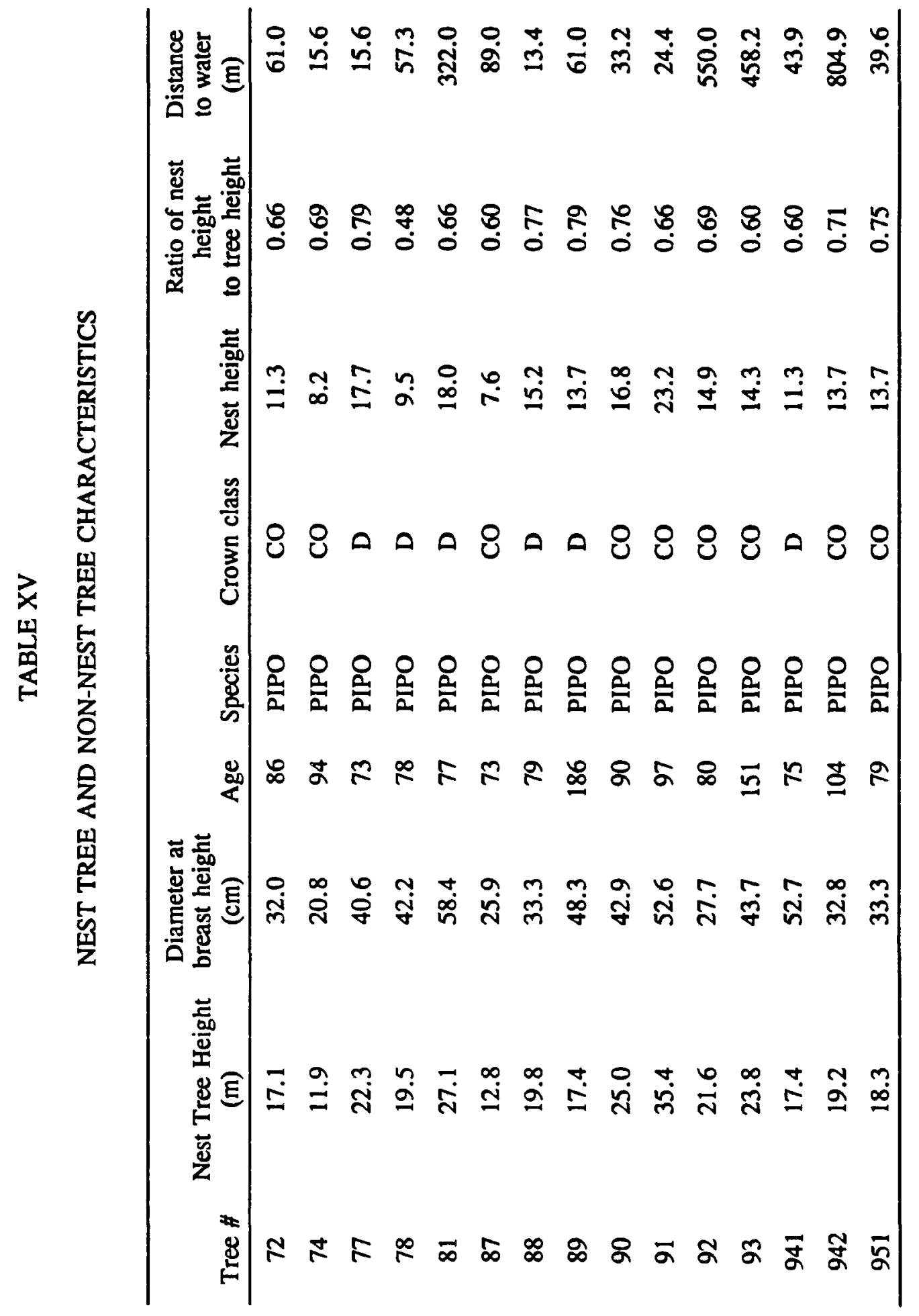




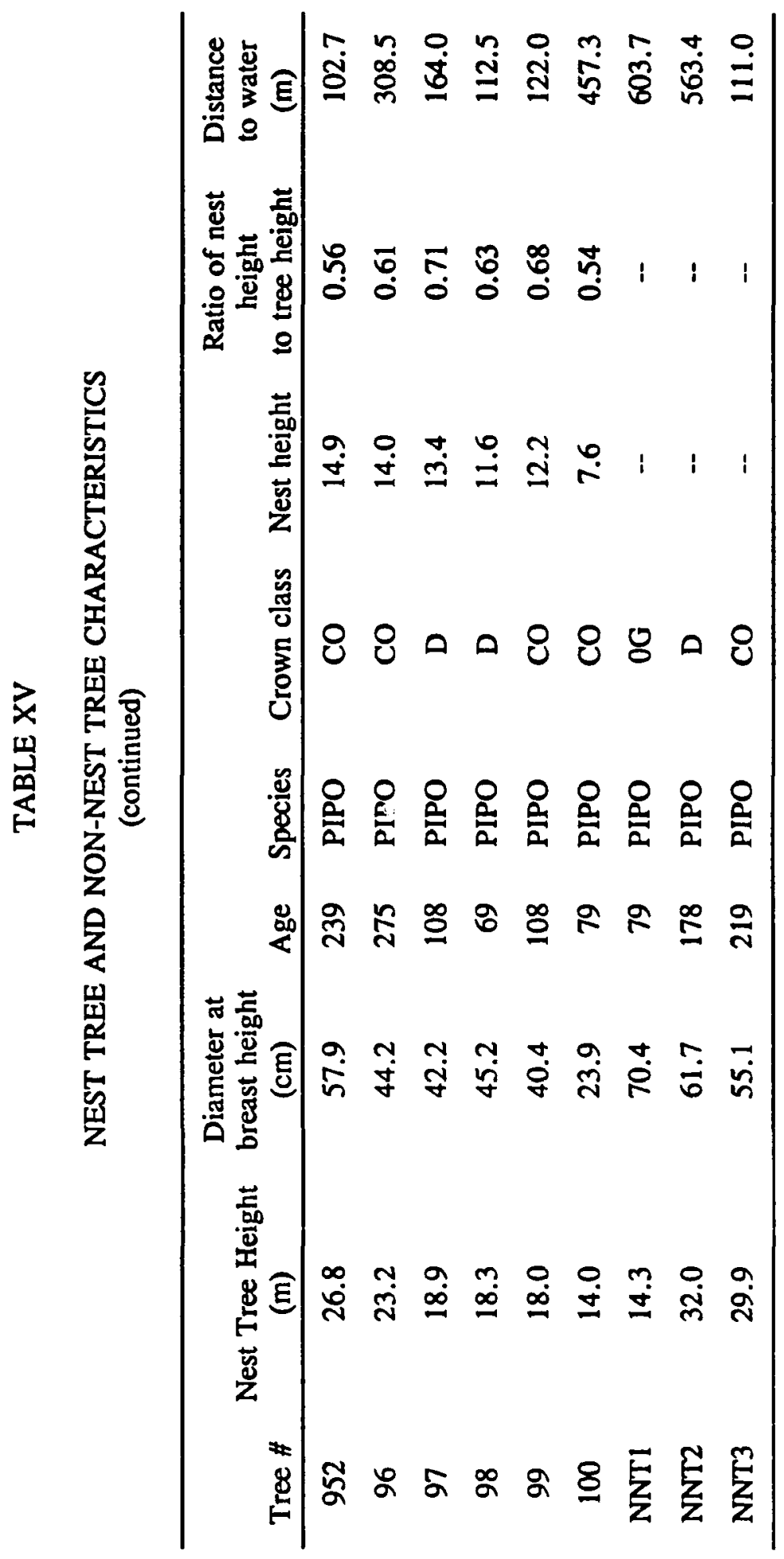


ponderosa pine. One nest not included in the analysis was in a Douglas-fir. This nest was used by a male during the summer and was located on a north-facing slope in Bear Gulch. The only other tree species in which nests were found were Q. garryana. These were "drays" or leaf nests constructed for short duration use or loafing.

Age of the nest trees ranged from 69 to 275 years with a mean of 108 years. The range of DBH of the trees within each 0.08 ha plot for nest trees was 20.8$58.4 \mathrm{~cm}(\bar{x}=21.6 \mathrm{~cm})$. The crown class of the trees within the plot was categorized into five classes: (a) dominant-8 nest trees and 1 non-nest tree; (b) codominant-13 nest trees and 1 non-nest tree; (c) intermediate-no nest trees; (d) suppressed-no nest trees; and (e) open grown (having no contiguous trees)-no nest trees and one non-nest tree.

Nest tree height for the 21 sites ranged from $12.7 \mathrm{~m}$ to $35.1 \mathrm{~m}(\bar{x}=20.2 \mathrm{~m})$. Nests were located approximately one-third the way down from the top of the tree next to the trunk on or within two adjacent branches. The ratio of the height of the nest tree to the height of the nest ranged from 0.48 to $0.79 \mathrm{~m}(\overline{\mathrm{x}}=0.63 \mathrm{~m})$.

Site characteristics (see Table XIV) included measurement of the percentage of canopy closure in quadrants formed from the four cardinal directions. Observations of the percentage canopy closure estimated for the northeast, southeast, southwest, and northwest quadrants revealed that one quadrant tended to be more open than the other three. Both of the south-facing quadrants were more commonly open than the north-facing quadrants (58\%). From ground observations these more open canopy 
quadrants frequently faced onto a meadow, a road, a creek or other open area.

Aspect and slope were measured for each site and were highly variable (see

Table XIV). Further characterization of each site included an estimation of the percentage occurrence of a variety of habitat components (see Table XVI). At each of the four cardinal compass directions, a variable plot (VP) (Dillworth \& Bell, 1982) was located $30.2 \mathrm{~m}$ from the nest tree. In each variable plot, the total basal area was measured with a five-gauge prism. The resulting data revealed the number of trees

\author{
TABLE XVI
}

PERCENTAGE OF COVER IN ONE-FIFTH ACRE PLOT OF NEST TREE SITES

\begin{tabular}{lccc}
\hline \multicolumn{1}{c}{ Characteristic } & Mean & Range \\
\hline Mature trees $>12 \mathrm{ft}$ & $59.86 \%$ & $35-85$ \\
Reproduction trees $<12 \mathrm{ft}$ & $3.80 \%$ & $0-10$ \\
Tall shrubs & $5.70 \%$ & 0 & -20 \\
Low shrubs & $17.30 \%$ & 0 & -60 \\
Herb cover & $43.40 \%$ & $3-95$ \\
Exposed bare rock & $12.20 \%$ & 0 & -45 \\
Total trees & $79.60 \%$ & 15 & -213 \\
Height tallest trees & $77.3 \mathrm{ft}$ & 42 & $-120 \mathrm{ft}$ \\
\hline
\end{tabular}


surrounding each nest tree and each non-nest tree site and served to characterize the stand within which the nest tree site was located (see Table XVII).

Maps of five representative nest tree sites are included (Figures 6 through 10). Maps of the other sites can be found in Appendix C. Nest Tree Site 072 (see Figure 6) contained a total of 116 trees and represented a pole stand in terms of the density and size of the trees. The predominant species was ponderosa pine; the other 11 trees were Oregon white oak (see Table XIV). A second nest tree was located within the FAP as indicated by a + sign in Figure 6. The canopy cover in all quadrants was $50 \%$ or greater. Distance to water was $15.6 \mathrm{~m}$ measured with a tape. Nest Tree Site 081 (see Figure 7), represented a site that contained 34 ponderosa pine and no other species of trees inside the FAP. There were 88 trees in the four variable plots that were also ponderosa pine. This site contained another nest tree represented by a + on the map. Canopy closure ranged from $20-50 \%$. Distance to water was calculated to be $322 \mathrm{~m}$.

Nest Tree Site 089 (see Figure 8) contained a total of 167 trees: 52 ponderosa pine, 103 Oregon white oak, 12 Douglas-fir. Many of the oaks were small diameter trees with a DBH of $2.5 \mathrm{~cm}$ to $12.7 \mathrm{~cm}$. This contributed to a low mean DBH of $10.5 \mathrm{~cm}$ for the site (range 1.5 to $48.3 \mathrm{~cm}$ ). Canopy closure was high with an average of $53.8 \%$ for the three most densely covered quadrants and $30 \%$ for the most open quadrant. The site was located on the north side of Bear Gulch on a $45^{\circ}$ slope and was a continually occupied nest for the duration of this study. A continually occupied site was considered to be a prime site for this study. The nest at this site 
TABLE XVII

BASAL AREA OF NEST TREE SITES

\begin{tabular}{|c|c|c|c|c|c|c|}
\hline Site \# & Total & VP-N & VP-E & VP-S & VP-W & $\begin{array}{l}\text { \# of } \\
\text { trees }\end{array}$ \\
\hline 072 & 330 & 30 & 60 & 50 & 70 & 66 \\
\hline 074 & 400 & 100 & 30 & 75 & 45 & 80 \\
\hline 077 & 395 & 60 & 30 & 90 & 70 & 79 \\
\hline 078 & 360 & 45 & 100 & 55 & 60 & 72 \\
\hline 081 & 540 & 135 & 65 & 135 & 105 & 105 \\
\hline 087 & 260 & 15 & 75 & 10 & 40 & 52 \\
\hline 088 & 435 & 70 & 125 & 35 & 65 & 87 \\
\hline 089 & 355 & 85 & 85 & 25 & 75 & 71 \\
\hline 090 & 490 & 150 & 120 & 70 & 35 & 98 \\
\hline 091 & 370 & 55 & 145 & 30 & 65 & 75 \\
\hline 092 & 430 & 90 & 80 & 95 & 90 & 86 \\
\hline 093 & 420 & 60 & 85 & 110 & 60 & 86 \\
\hline 941 & 390 & 100 & 35 & 05 & 55 & 78 \\
\hline 942 & 340 & 60 & 65 & 115 & 10 & 68 \\
\hline 951 & 380 & 55 & 30 & 45 & 110 & 76 \\
\hline 952 & 320 & 5 & 95 & 85 & 55 & 64 \\
\hline 096 & 510 & 105 & 110 & 100 & 90 & 102 \\
\hline
\end{tabular}


TABLE XVII

BASAL AREA OF NEST TREE SITES

(continued)

\begin{tabular}{lcccccc}
\hline Site \# & Total & VP-N & VP-E & VP-S & VP-W & $\begin{array}{l}\text { \# of } \\
\text { trees }\end{array}$ \\
\hline 097 & 565 & 90 & 100 & 125 & 135 & 113 \\
098 & 280 & 70 & 10 & 130 & 30 & 56 \\
099 & 345 & 40 & 85 & 55 & 95 & 69 \\
100 & 470 & 70 & 195 & 40 & 40 & 94 \\
NN1 & 75 & 10 & 30 & 30 & 5 & 15 \\
NN2 & 130 & 35 & 55 & 30 & 10 & 26 \\
NN3 & 460 & 115 & 90 & 75 & 70 & 80 \\
\hline
\end{tabular}

was also frequently used by the Channel $\mathrm{V}$ squirrel and was located in the center of his winter home range. Nest Tree Site 091 (see Figure 9) was located in Jordan Creek on an island between two branches of the creek. This was also a prime site. It contained a few very tall, large diameter trees. The total number of trees was 15 , but the species variety was 4 , with 12 ponderosa pine, no Oregon white oak, 1 Douglas-fir, 1 Grand fir (Abies concolor), and 1 mountain alder (Alnus incana). The average DBH was $48.9 \mathrm{~cm}$ with a range of $13.3-71.5 \mathrm{~cm}$. This represented the largest diameter of trees found in nest trees during the study. Distance to water was 
KEY:

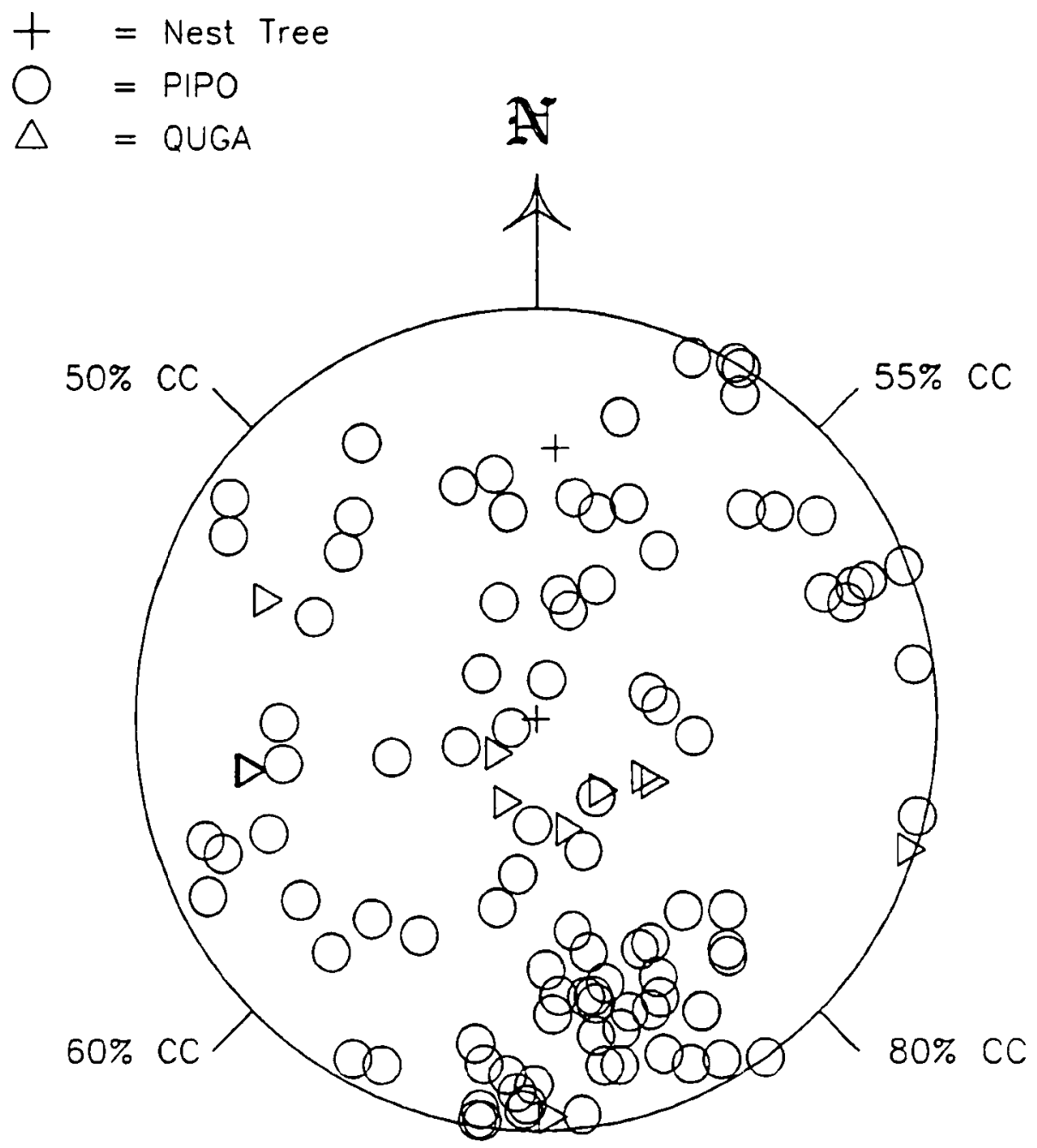

Figure 6. Nest tree site 072. Note: Abbreviations as in Figure 2. 


$$
\begin{aligned}
\frac{\text { KEY: }}{+} & =\text { Nest Tree } \\
\bigcirc & =\text { PIPO }
\end{aligned}
$$

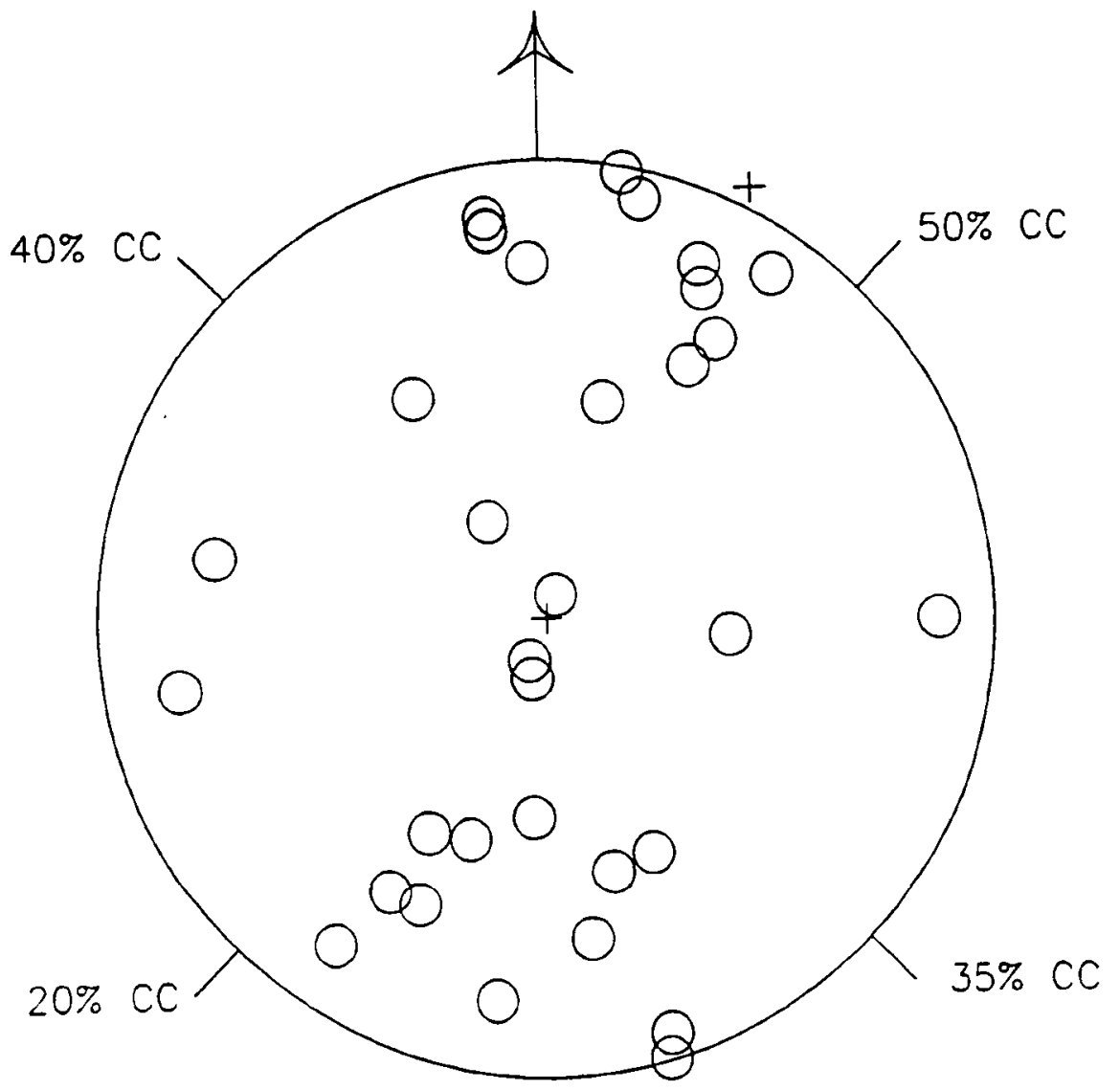

Figure 7. Nest tree site 081. Note: Abbreviations as in Figure 2. 


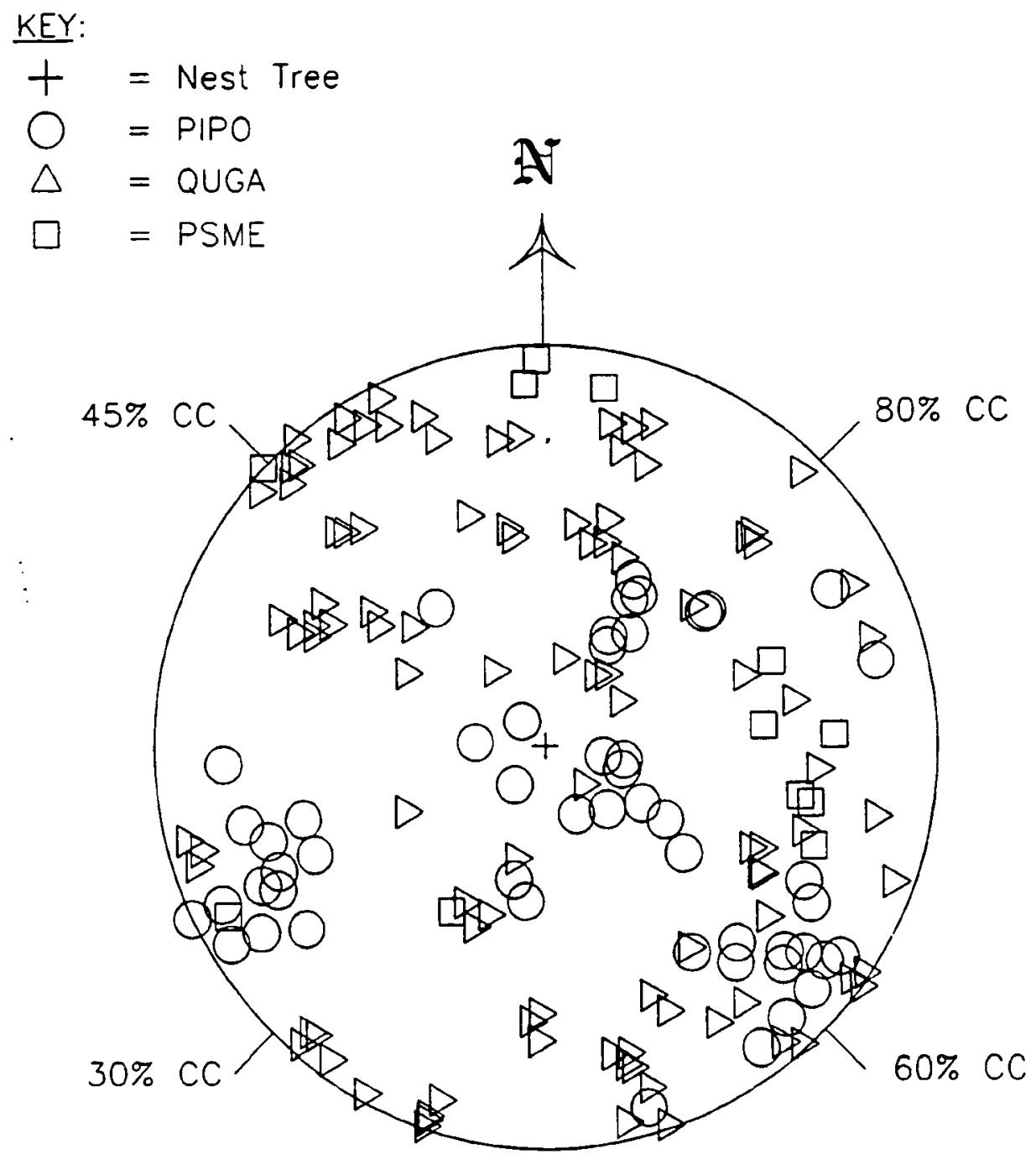

Figure 8. Nest tree site 089. Note: Abbreviations as in Figure 2. 


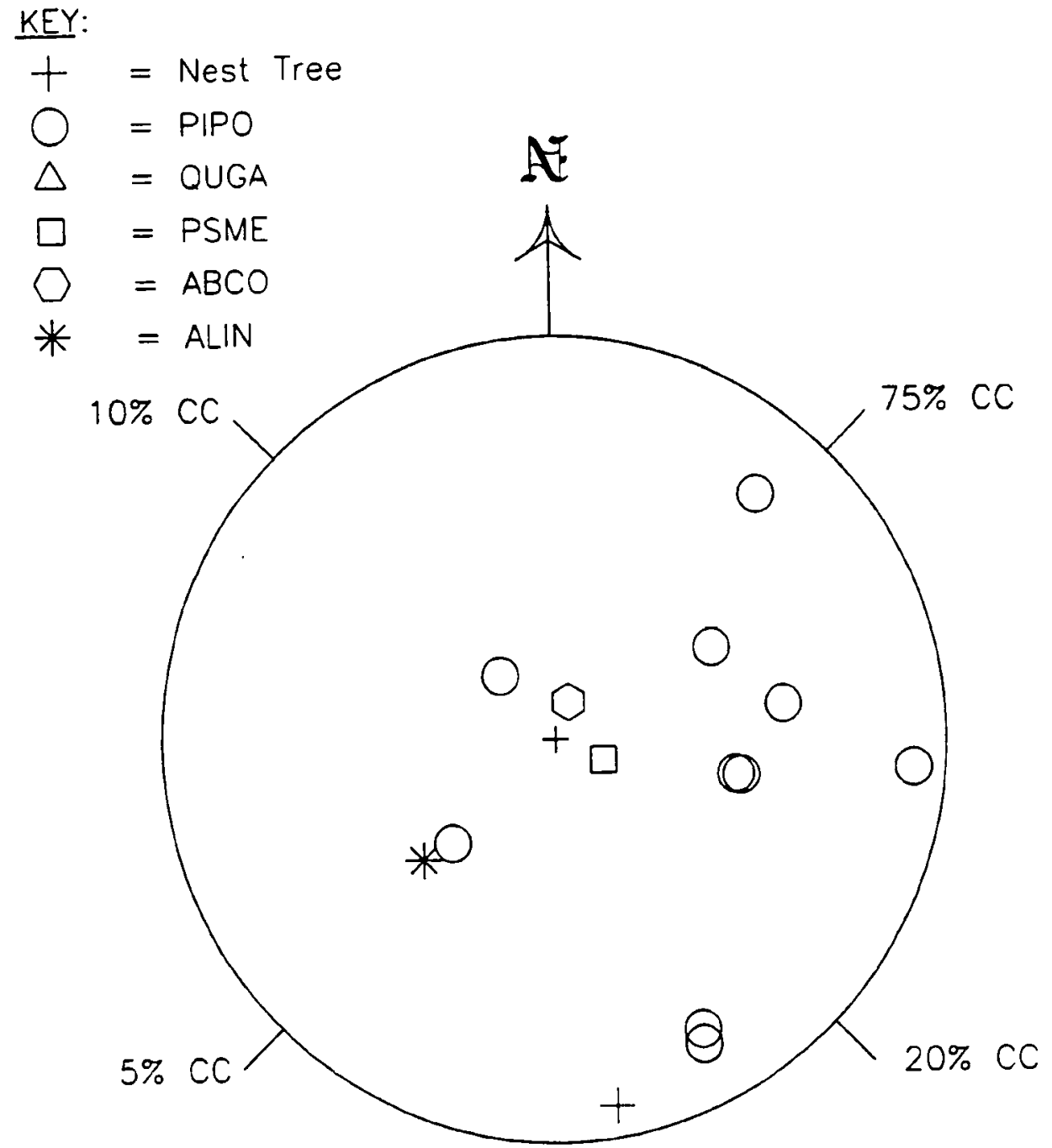

Eigure 9. Nest tree site 091. Note: Abbreviations as in Figure 2. 


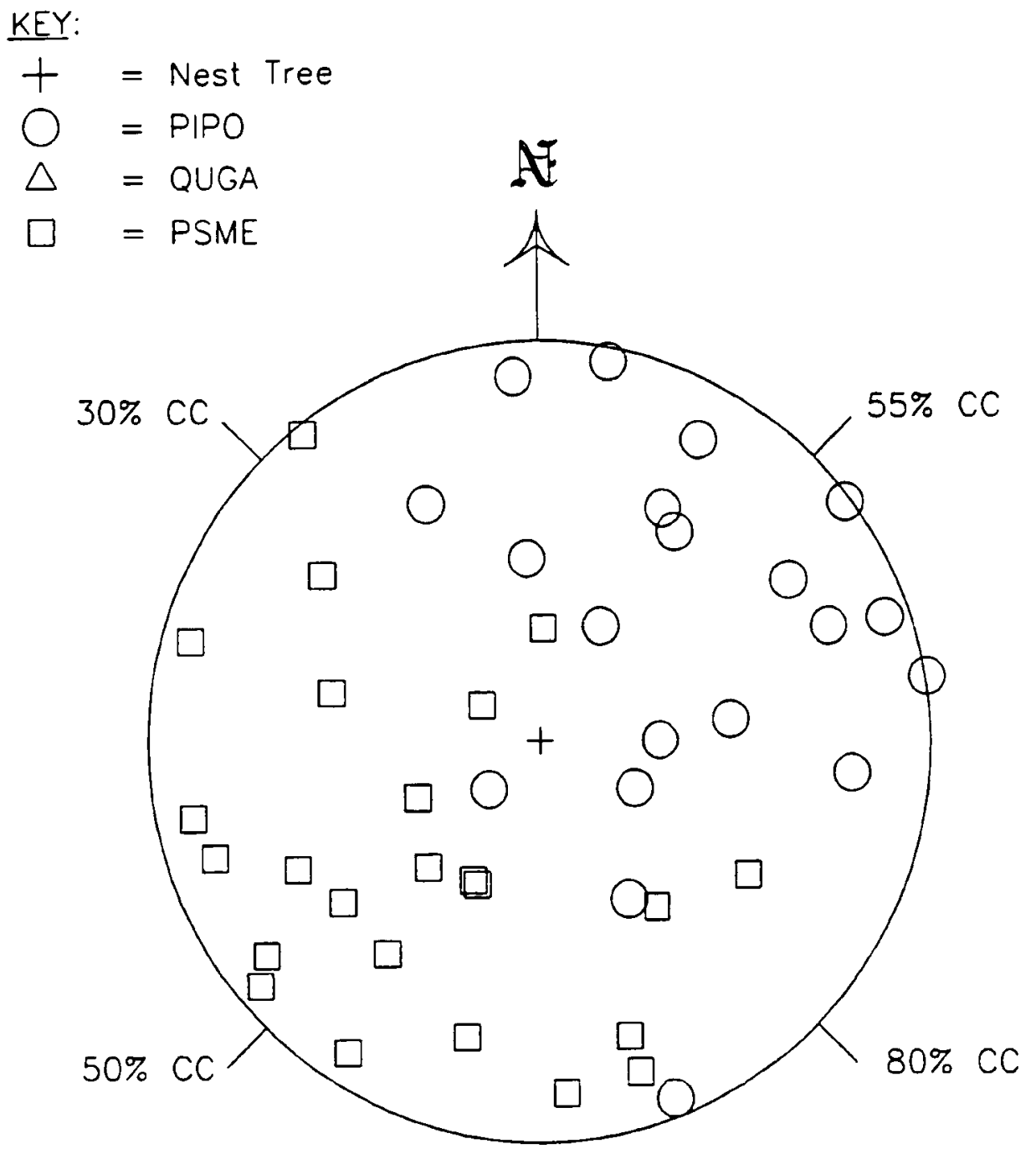

Eigure 10. Nest tree site 092. Note: Abbreviations as in Figure 2. 
$24.4 \mathrm{~m}$. Canopy closure for the least open quadrants averaged $27.5 \%$; the most open quadrant had 5\% canopy closure.

The last figure mentioned here, Figure 10, represents a site (092) with more Douglas-fir than usual. This site was located in the Out Timber Sale on the flat above Badger Creek. It included the major nest of Channel I squirrel of the home range study. The total tree count was 44 with 21 ponderosa pine, no Oregon white oak, and 23 Douglas-fir. DBH ranged from 10.5 to $42.2 \mathrm{~cm}$ with an average of $24.5 \mathrm{~cm}$. Canopy closure averaged $53.8 \%$ for the three most closed quadrants and $30 \%$ for the most open quadrant. The measurements were made in the summer, and the nearest water was mapped at $550 \mathrm{~m}$; however, a deep ravine was located $152.3 \mathrm{~m}$ from the nest tree and could have contained water during most of the year. The high number of Douglas-fir was unusual for the sites mapped in this study.

A nest that was occupied continually for 5 years was removed from the tree after it was observed and photographed from nest height by Oregon Department of Fish and Wildlife biologist John Beck. The nest (see Figure 11) was $92 \mathrm{~cm}$ long, $46 \mathrm{~cm}$ high and consisted of two parts: a large round ball, which was the enclosed nest of about $46 \mathrm{~cm}$ in outside diameter; and a resting platform beside the nest that was also $46 \mathrm{~cm}$ in length. The nest itself was constructed of pine boughs and needles for the outer $8 \mathrm{~cm}$. The spacing between the boughs was solid with packed soil. Perhaps dirt had blown into the outer part of the nest, because squirrels have not been reported to carry soil. The soil gave great strength to the nest, making it difficult to 


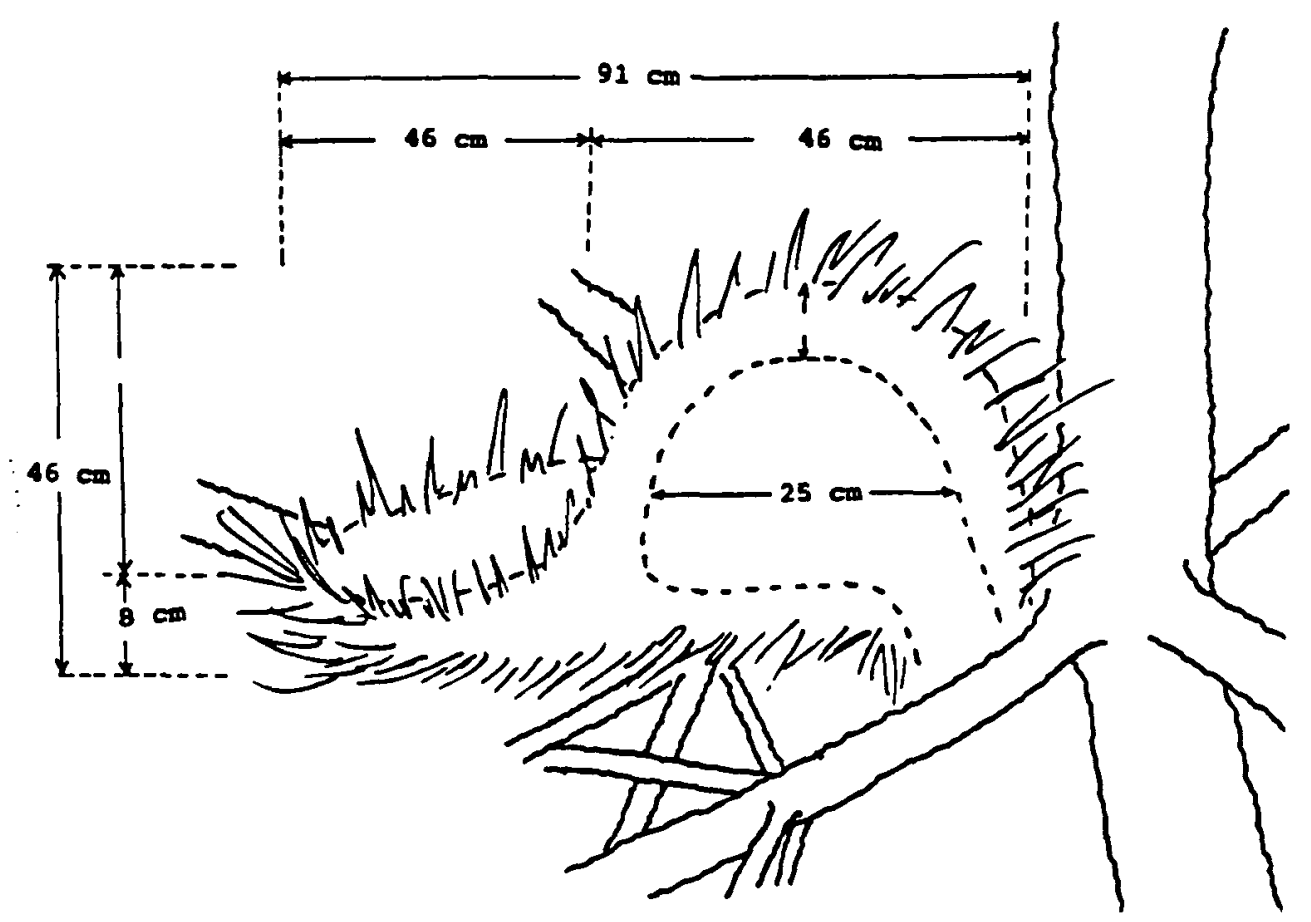

Figure 11. Cutaway side view of a western gray squirrel nest taken from a prime nest site. 
open. The inner cavity of the nest was $25 \mathrm{~cm}$ in diameter and lined with shredded grasses, lichens and moss.

Observation of the construction of nests by both juvenile and adult squirrels revealed that the squirrels cut pine boughs and carried them to a tree with two or more branches arising from the trunk at the same point, providing the foundation for a platform on which to build the nest. In addition to pine boughs, oak branches with leaves were often used. When the outside had been completed, squirrels carried large mouthfuls of shredded grass into the nest. The squirrel's age may influence the quality of nest construction. In one 45-minute period, an adult squirrel was observed building a nest that remained in place for a year. In contrast, two immature animals spent 2 hours in nest construction with marginal success, as the first branches fell to the ground as succeeding branches were added. This process continued throughout the observation period.

Twenty nest boxes constructed by Centennial High School biology students were placed in the Out Timber Sale area between Badger and Jordan Creek 1 year before timber was removed. The design of the boxes was provided by the Oregon Department of Fish and Wildlife (see Appendix D). None of the boxes were ever observed to be occupied in the field. Two nest boxes were also placed at Friend, the squirrel release site and feeding station. One was occupied by an adult squirrel. The squirrel was afflicted with scabies and eventually was no longer observed. The same nest box was then occupied by a recently released juvenile male. This squirrel also developed scabies, so the box was removed for cleaning. When the box was emptied, 
it was noted that the previous occupant had filled the box half full of branches, leaves and needles, and was dead in the box. The juvenile squirrel had been nesting on top of both vegetation and dead squirrel, so the box was replaced with a new one. The juvenile tried once to use it, slid to the bottom of it, climbed out and did not again retum to the nest box. 


\section{CHAPTER VI}

\section{DISCUSSION}

Although habitat preference in animals appears to be innate (Robinson \& Bolen, 1989), habitat selection depends upon the available critical resources, such as food, water, cover and space. As noted, westem gray squirrels occur from northern Washington to southern California. The specific vegetational components of the squirrel's habitats change with climate and latitude; however, throughout their range these squirrels require large mast-producing trees, a fungal food source, trees of sufficient size and arrangement for nests, and access to water.

When this study began in 1981, squirrels were easily observed and trapped in my study areas. The animals continued to be evident and trapable through 1982 and 1983. Returns from the Hunter Cooperation Program indicated a relatively stable population, with sample sizes of 106 in 1981, 109 in 1982, and 144 in 1983. The large number in 1983 may have been directly due to an article published in an issue of Field and Stream entitled "Hunt For Silver" (Park, 1983). Hunters reported that they were hunting in the area because of the information in the article about the northcentral Oregon western gray squirrel population and about this study.

Following the winter of 1983-1984, fewer western gray squirrels were observed, and the Hunter Cooperation Program produced fewer individuals. Fifty-seven squirrels were obtained in 1984, 34 in 1985, and 45 in 1986 (see Table XII). A 
number of hunters who had contributed each year to the study reported in 1985 and 1986 that they would not be hunting until the population increased again. Only 20 squirrels were returned through the Hunter Cooperation Program in 1987. Trap success also indicated a decline in the population, as shown by the increase in the number of trap days per squirrel captured in 1985 and 1986 (see Table VI).

The sex ratio of the squirrels taken in the Hunter Cooperation Program show a relatively even balance between males and females, with 245 (47.6\%) males to 223 (43.3\%) females over the 7-year period. Barnum (1975) collected 96 western gray squirrels over a 17-month period for a study of their reproductive patterns. Forty-six of the squirrels were male and 50 were female, but Barnum did not state whether this sample was representative of the population. Of 63 squirrels captured by Cross (1969) in Southern Oregon, 39 were male and 24 were female. Hall (1980b) live-trapped western gray squirrels in the Geysers area of California, live-trapped western gray squirrels during the spring and fall of 1978. Sex ratios were similar to mine and those reported by Cross (1969), with more males than females in the spring and approximately equal numbers of males and females in the fall. Sex ratios are not specifically mentioned in other studies. These data all suggest that males are more catchable during the spring, but by fall the population has shifted toward more females than males. The shift is not large, but the lower number of females seen and taken in the spring could reflect females spending more time in the nest because of gestation and early lactation. 
The body weights of squirrels in this study ranged from 525-925 $\mathrm{g}$ with an average of $806 \mathrm{~g}$ for males, and $500-950 \mathrm{~g}$ with an average of $781 \mathrm{~g}$. for females. Pregnant females weighed the most at $950 \mathrm{~g}$. These weights were slightly lower than those reported by other investigators. For example, Asserson (1974) reported that in Kern County, California, adult squirrels weighed 709-963 $\mathrm{g}(\overline{\mathrm{x}}=811 \mathrm{~g})$; males weighed 709-907 $\mathrm{g}(\overline{\mathrm{x}}=794 \mathrm{~g})$, and females weighed 652-963 $\mathrm{g}(\overline{\mathrm{x}}=828 \mathrm{~g})$. Data from Swift (1977) in Butte County, California, showed a broader range of weights for adult males and females.

The body lengths of the squirrels in this study ranged from $27-39 \mathrm{~cm}(\overline{\mathrm{x}}=32.9)$ for males and $27-35 \mathrm{~cm}(\bar{x}=30.8)$ for females. Tail lengths were not significantly different between the sexes, although the average for males was $31.8 \mathrm{~cm}$ and for females it was $31.3 \mathrm{~cm}$. Body lengths for squirrels in this study were larger than those reported by Swift (1977), although the same squirrels' body weights were slightly smaller.

Data on the food habits of western gray squirrels from this study support the data from other investigators such as Bailey (1936), Ingles (1947), Stienecker and Browning (1970), Stienecker (1977), and Cross (1969). Each of these investigators have discussed the reliance of the squirrels upon pine seeds of various species during late summer depending upon their location and the use of acoms, when they are available, to supplement the winter diet. In the habitat of the western gray squirrel in north-central Oregon, reliance on large mast is restricted to that of ponderosa pine trees. There is extensive competition for acorns from other birds, deer and other 
sciurids. A preliminary sample of stomachs collected in the study area indicate the same strong reliance of the squirrel upon hypogeous and epigeous fungus as other investigators have found (Bailey, 1936; Cross, 1969; Ingles, 1947; Stienecker, 1977; Stienecker \& Browning, 1970). More recent work by Maser, Trappe, and Nussbaum (1978), Fogel and Trappe (1978), Byme (1979), McIntire (1984) and Maser, Maser, and Trappe (1985) reported the heavy utilization of hypogeous and epigeous fungi by western gray squirrels. Rhizopogon is the predominant genus of hypogeous fungi in the above-mentioned studies and also in the small sample of stomachs examined in this study. Rhizopogon is one of the most common hypogeous fungi in mixed coniferous forests. This genus occurs specifically in association with species of Pinaceae. Species of Rhizopogon fruit most commonly from early fall through early winter, but the sporocarps can be found through the year (Castellano, Trappe, Maser, \& Maser, 1989). Nine of the 14 stomachs examined in this study included Rhizopogon. Reports in the literature of the importance of small mammals as disseminators of fungal spores tends to support the importance of the western gray squirrel's role in this activity. Only two of the 14 stomachs examined here did not contain fungal spores. When one considers that acorns are produced in sufficient quantities to be a staple food on the average of only once in 7 years (U.S. Department of Agriculture, 1965) and that a number of competitors for this fall and winter food source were observed during this study, the reliance of the western gray squirrels upon fungi, and especially hypogeous fungi, becomes more apparent. Competition for acorns comes from Merriam's turkeys, California ground squirrels, yellow-pine 
chipmunks, Douglas' squirrels, northern flying squirrels, mule deer and elk. Byrne (1979) considered the reliance of western gray squirrels on hypogeous fungi to be the main factor accounting for the different distributions of eastern gray and fox squirrels as contrasted with western gray squirrels in Northern Califomia. Eastern gray squirrels and fox squirrels relied more upon domestically produced nuts from orchards.

Several references have been made in the literature to squirrels eating the cambium of conifers during some seasons. Western gray squirrels have been seen stripping bark from the upper sections of redwoods, (Fritz, 1932, cited in Ingles, 1947), and ponderosa pine, (Baldwin, 1980; Cross, 1969). This activity was not observed in the present study.

My analysis of the contents of 14 stomachs involved less than $1 \%$ of the stomachs provided through the Hunter Cooperation Program. The analysis requires considerable time and a reference collection from which to work. Even this small sample size, however, provided supporting information about the intermittent availability of acoms, as the primary source of starchy material as a late fall and winter supplemental food (see Table I). In several years during this study (e.g., 1982, 1983, 1985, and 1986) Oregon white oaks produced few if any acorns. This failure of mast production is a characteristic of this tree species. The reason for the lack of production is unknown (U.S. Department of Agricultural, 1965). Failure of the acorn crop causes the animals that depend on this food to seek other food resources. Pine seeds in the late summer and early fall provide a valuable supplement 
for the accumulation of winter fat, but cannot compensate for the loss of acorns, because the squirrels eat pine seeds in the cones when they are green.

In an ideal year, the annual diet of the western gray squirrel is: acorns from winter through early spring; fungi, both hypogeous and epigeous, from early spring through late fall; ponderosa pine seeds from late summer through fall; and succulent vegetation from late spring through early summer.

The habitat of the western gray squirrel at the sites studied is characterized primarily by ponderosa pine and Oregon white oak. With erratic production of acorns being characteristic of Oregon white oak, pine seeds become increasingly important in the squirrel's diet. Pine seeds are at best a seasonally limited food. When they are also in low supply, the result is the loss of much of the population of squirrels. This loss comes as a result of the poor physical condition of the squirrels from insufficient food. Squirrels are then more susceptible to endemic parasites such as skin mites that cause scabies. Scabies results in the loss of hair and, consequently, diminished thermoregulation, which leads to death.

A study by Smith (1970), on the co-evolution of Tamiasciurus species and pine trees, indicate that over time pine trees evolve mechanisms that prevent high levels of predation on the cones by squirrels. These adaptations include: (a) producing cones that have few seeds, (b) producing cones that are hard to open, (c) increased thickness of the seed coat, (d) less nutritious seeds, and (e) cones that drop the seeds early in the season before the young squirrels are out of the nest. Although no information is available on the ability of ponderosa pine to minimize seed loss due to predation by 
squirrels, many of the ponderosa pines in the study area produced few seeds per cone or cones with no seeds in 1983.

In northcentral Oregon and in my study area specifically, trees that produce large-sized mast are limited to ponderosa pine and Oregon white oak. In other areas of the squirrel's range there is a greater variety of mast-producing trees, such as madrone, Oregon white oak, Califomia black oak, and sugar pine (Pinus lambertiana). With the continued and accelerated loss of the large cone-producing ponderosa pine throughout much of the western gray squirrel's habitat from timber harvest, and the difficulty in growing oak trees, western gray squirrel populations are probably increasingly prone to rapid decreases in population size, as are Kaibab and Abert's squirrels (Patton, 1984). Both of these squirrels have a close dependence upon ponderosa pine for food, cover and nesting. Abert's squirrel does not store food for winter use, but feeds on the inner bark of twigs, pollen from staminate cones, seeds from ovulate cones, and hypogeous fungi associated with the roots (Patton, 1984).

Size of home ranges can be directly associated with the space needed to find sufficient food. Larger home ranges require greater energy expenditure for the squirrels, as they cover a greater area to meet their food requirements. The large home ranges of the squirrels I studied suggests extensive competition with conspecifics and other species, for acoms, pine seeds in fall and winter, and for hypogeous fungi throughout the year. Males averaged 4.38 ha per squirrel, and females averaged 4.03 ha (see Table XI). Cross (1969) in southern Oregon found 
average home ranges of $0.74-7.09$ ha. Sizes of the ranges changed seasonally. Summer home ranges were smaller than those in early fall, with the upper end of the range occurring at the times of the year when food was scarce. Ingles (1947) found home ranges of $1.15-1.85$ acres for males and $0.300-0.85$ acres for females in central California. Gilman (1986) found that males in northern California used home ranges of 2.3-3.6 ha $(\bar{x}=2.5 \mathrm{ha})$, and females used home ranges of 2.0-4.2 ha $(\bar{x}=2.6$ ha). Hall (1980b), working in the Geysers area of central California, found that home ranges differed in various habitats but averaged less than one hectare. In knobcone pine areas western gray squirrels occurred at a density of 2.5 per ha, in yellow pine at 2.9 per ha and in mixed coniferous forests at 3.3 per ha. He concluded that the increase in numbers of squirrels per hectare was due to the increase in mast in the habitat. Asserson (1974), in Kern County, California, described home ranges for males that averaged 0.15 ha and females that averaged 0.14 ha. Although the home ranges reported in this study are considerably larger than those further south, they are close in size to those reported for other Sciurus species in southwestern United States. Perhaps in both cases the habitat is of marginal quality for Sciurus species.

The quality of the habitat is influenced by the number of mast-bearing tree species in and near the nest tree sites, and age and size of the trees. In a relatively undisturbed stand when the number of trees was smallest, the trees were largest and had broad interconnected canopies. Nests were always located about one-third of the distance down from the top of the tree. The nest was located at a juncture of 
branches large enough to support a nest. There did not appear to be a preferred branch size or configuration other than having two or three branches protruding from the bole at the same location of sufficient closeness to support twigs and branches used as the base of the nest.

An important feature associated with all nest trees was the contiguous crowns of neighboring trees providing aerial routes of travel for some distance from the nest tree. Squirrels are cautious in their approach to the nest, possibly to avoid predators and nest competitors. Neither hand-raised nor wild squirrels would return to the nest directly, but would instead enter the canopy several trees from the nest and work their way through the canopy to their nests. Squirrels would not move into the nest tree if I was watching them. However, if I turned my back, they would quickly enter the nest.

Several sites that were continuously occupied throughout the first 6 years of the study were termed "prime" sites. These sites were close to permanent water, had a number of conifers with contiguous canopies, and were in mixed pine-oak stands. At one of these prime sites, on two occasions the occupying western gray squirrel was killed by a bobcat. The first kill occurred after a $2.54 \mathrm{~cm}$ snowfall. The tracks of both animals revealed the progression of stalking, chase and kill. In neither case did the bobcat eat the tail, large intestine, gall bladder or radio-collar of the squirrel. In contrast, a squirrel killed by a coyote was apparently devoured except for some fur. The nest of squirrel killed by the bobcat was occupied within 2 weeks by another squirrel. The nest was maintained at least through 1989. 
Reproductive activity in western gray squirrels occurs during much of the year. Estrous was recorded from January through March and again in June. Pregnancies were recorded from January through March and again in August. Lactation was recorded from March and April and again in July through October. Nonbreeding individuals were also found from March through January. These data are consistent with those of other researchers in that there are two periods of time during which litters are produced. Each female produces one litter per year with the majority of production occurring in what is termed the summer litter or the second peak of reproduction. These second (summer) litters contribute most successfully to population recruitment.

Disruptions in the food supply, lack of areas for dispersal, and hunting of squirrels during the late summer cause population decline. A female squirrel that does not have an adequate winter food supply will have few reserves from which to sustain herself and a litter if she should become pregnant in the first part of the breeding season. This would favor a larger number of breeding females in the later period of estrous of May through July. Onset of the first breeding season appears to be related to the onset of the second period in that both may be influenced by severe weather early in the year. When spring is delayed by inclement weather, the onset of the peaks of breeding are also delayed. This results in the taking of lactating females during the first part of the fall hunting season. The timing of the fall hunt appears to be important in maintaining a viable squirrel population. Data from the Hunter Cooperation Program show that the majority of western gray squirrels taken during 
the hunting season are adults and old adults. These are the animals that are the major producers of young in the population. The continued loss of these members from the population and the taking of lactating females whose young are not likely to survive, together with the loss of useable habitat to logging and occurrence of harsh weather will have profound effects on population size, stability, durability and possibly genetic composition of the squirrel population. It is reasonable to argue that removal of adults and old adults in greater proportion than the subadults or juveniles presents a problem in the timing of the hunting season.

Logging most often removes ponderosa pine from the habitat. These large, mature trees are needed by western gray squirrels for food and cover within the habitat. In unmanaged tree stands, a squirrel can select from a wide variety of combinations of tree size, form, and density to meet its needs (Patton, 1984). Under natural conditions, ponderosa pine tends to grow in stands of uneven age, with evenaged groups within the stand. To date, over $50 \%$ of the nest trees and sites used in this study have been logged.

The decline of the western gray squirrel population in northcentral Oregon can be attributed to both natural and human-caused activities. It is possible that changes in long-term weather pattern have affected the area and its precipitation. The range of the western gray squirrel at one time extended northward through central Washington. The squirrel's status in Washington is listed as "sensitive." The Non-Game Division of the Washington Department of Game has proposed that the status of the western gray squirrel be changed to threatened. The squirrel has 
suffered extensive habitat loss in much of its range, but that does not explain its disappearance over most of its previous range in Washington.

In northcentral Oregon the western gray squirrel populations appear to occupy marginal habitats. The increase in logging, the difficulty with which ponderosa pine can be regenerated after cutting, the pattem of "leave-trees" in clear cuts, the unpredictable food supplies, the variable precipitation patterns, and the impact of the early hunting season on the species have combined to produce a habitat that is not favorable to continued survival of the western gray squirrels. These factors have been compounded by the introduction of Merriam's turkeys which I observed competing with western gray squirrels for winter food. 


\section{CHAPTER VII}

\section{CONCLUSIONS AND RECOMMENDATIONS}

\section{CONCLUSIONS}

Northcentral Oregon is, under natural conditions, marginal habitat for western gray squirrels. Due to habitat changes resulting from both natural and human causes, the squirrel population began to decline in the winter of 1983-1984. The decline is correlated with the loss of their major fall food supply, ponderosa pine seeds due to inclement weather. In the spring of 1983, rain interfered with good pollination in ponderosa pine; thus, the cones in 1984 were largely empty. The spring of 1983 was also delayed by late freezes when the acoms would have been setting on the trees. This led to a lack of acorns over much of the forest. With the loss of two of the major foods needed to produce fat accumulation sufficient to offset the shortages of winter, the squirrels were stressed. Endemic in the population is scabies, a skin condition caused by the mite, Notoedras douglasi, which became widespread in the squirrel population in 1984. Due to resulting hair loss and to food shortage, many squirrels died of hypothermia, starvation, or both. The population probably could have recovered from this outbreak within a few years, but with the accelerated rate of logging in the Barlow Ranger District, available habitat and resources for western 
gray squirrels was reduced. Continued squirrel hunting during the period of greatest reproductive potential-late August through mid-September-accentuated the losses.

The habitats investigated in this study are larger than for other populations of this squirrel in southern Oregon and California, as a result of the squirrels having to travel further to meet their needs for food, water and nest sites. Some changes in home range occur between summer and winter. Summer ranges include north-facing slopes while winter ranges tend to include south-facing slopes.

Field observations suggest that competition for nest sites, food, and space is increased in this area by the large number of other squirrel species present, the foraging of deer on acoms, and the introduction of Merriam's turkey into the area. The turkeys and deer compete with the squirrel for winter food.

Nest tree sites are located in habitats including a predominant mix of ponderosa pine and Oregon white oak. The stands within which the nests are located range from open, sparse stands to dense clusters of pole-sized trees which include a few larger pines. At least one to a few large mast-producing oaks are also present. Winter and breeding nests are located in codominant ponderosa pine trees. Nest sites are never in large, single pines, but rather in clusters of trees with interconnected canopy. This canopy is utilized by the squirrel for cover and travel.

\section{RECOMMENDATIONS}

Several practices would either maintain or enhance western gray squirrel habitat. These include the following: 
1. Maintain corridors of travel on the ground as well as in the canopy. When providing snags in timber removal areas, cluster the green trees left for future snags to provide both contiguous routes for travel and connect the clusters of snags to the side of a sale area.

2. Alter logging practices so as to maintain an interconnected canopy that would allow for aerial routes of travel for a distance of at least $60 \mathrm{~m}$ around nest trees which also need to be adjacent to or within interconnected arboreal corridors.

3. Provide a mix of both large Oregon white oak and ponderosa pine trees within the habitat for food, cover, and nest tree sites.

4. Maintain the above sites within $180 \mathrm{~m}$ of water, and enhance other potential nest tree sites by construction of water holding facilities.

5. Enhance habitat from which timber has been removed by planting mast-bearing trees such as California hazel and more Oregon white oak.

6. Clear-cuts or timber sale areas should be no larger than $60 \mathrm{~m}$ in width. If larger sizes are required, the sale area should be designed to provide for distances no more than $60.0 \mathrm{~m}$ from adjacent cover.

7. Areas within western gray squirrel habitat in which regeneration of ponderosa pine is difficult or impossible should be protected from timber removal.

8. Change the time of the fall hunt to the first of October to decrease the taking of lactating females in the hunt.

9. The bag limit should remain at low levels while the squirrel population levels are low. Recovery of the population should be carefully monitored until 
population recovery can be documented. Following recovery, bag limit should be set according to hunter pressure and the potential for naturally caused (e.g., available food) population decline. 


\section{REFERENCES CITED AND ADDITIONAL LITERATURE}

\section{REFERENCES CITED}

Allen, J. M. (1952). Gray and fox squirrel management in Indiana. Federal Aid Bulletin, 1, 112.

Asserson, W. C., III. (1974). Western gray squirrel study in Kern Co., California. California Fish and Game (Administrative Report No. 74-1), 1-32.

Bailey, V. (1936). The mammals and life zones of Oregon. Washington, DC: North American Fauna, 55, 1-416.

Baldwin, R. (1980). Westem gray squirrel damage to conifers in southern Oregon. Unpublished manuscript.

Barnum, D. A. (1975). Aspects of western gray squirrel ecology. Unpublished master's thesis, Washington State University, Pullman.

Barrier, M. J., \& Barkalow, F. S., Jr. (1967). A rapid technique for aging gray squirrels in winter pelage. Journal of Wildlife Management, 31(4), 715-719.

Brown, D. E. (1984). Arizona's tree squirrels (Publication No. W-53-R). Phoenix: Arizona Fish and Game Department.

Byrne, S. (1979). The distribution and ecology of the non-native tree squirrels Sciurus carolinensis and Sciurus niger in Northern California. Unpublished doctoral dissertation, University of California, Berkeley.

Carson, J. D. (1961). Epiphyseal cartilage as an age indicator in fox and gray squirrels. Џournal of Wildlife Management, 25(1), 90-93.

Castellano, M. A., Trappe, J. M., Maser, Z., \& Maser, C. (1989). Key to spores of the genera of hypogeous fungi of north temperate forests. Eureka, CA: Mad River Press.

Colburn, M. L. (1986). Suspensory tuberosities for aging and sexing squirrels. Joumal of Wildlife Management, 50(3), 456-459. 
Costain, D. B., \& Verts, B. J. (1982). Age determination and age-specific reproduction in Belding's ground squirrels. Northwest Science, 56(3), 230-235.

Cross, S. P. (1969). Behavioral aspects of western gray squirrel ecology. Unpublished doctoral dissertation, University of Arizona, Tucson.

Daniel, T. W., Helms, J. A., \& Baker, F. S. (1979). Principles of silviculture. New York: McGraw-Hill.

Dillworth, J. R., \& Bell, J. F. (1982). Variable probability sampling: Variable plot and three-p. Corvallis, OR: O.S.U. Book Stores.

Farentinos, R. C. (1972). Observations on the ecology of the tassel-eared squirrel. Journal of Wildlife Management, 36, 1234-1239.

Fiero, B. C., \& Verts, B. J. (1986). Comparison of techniques for estimating age in raccoons. Joumal of Mammalogy, $67(2), 392-395$.

Fisher, E. W., \& Perry, A. E. (1970). Estimating ages of gray squirrels by lensweights. Journal of Wildlife Management, 34, 825-828.

Fogel, R. D., \& Trappe, J. M. (1978). Fungus consumption (mycophagy) by small mammals. Northwest Science, 52, 1-31.

Forbes, R. B. (1966). Studies of the biology of Minnesotan chipmunks. The American Midland Naturalist, 76 (2), 290-308.

Franklin, J. F, \& Dyrness, C. T. (1973). Natural vegetation of Oregon and Washington (Technical Report PNW-8). Washington, DC: U.S. Department of Agriculture, Forest Service.

Gilman, K. N. (1986). The western gray squirrel (Sciurus griseus), its summer home range, activity times, and habitat usage in Northern California. Unpublished master's thesis, California State University, Sacramento.

Hall, D. J. (Ed.) (1979). Western gray squirrel studies at The Geysers-Calistoga known geothermal resources area. Transactions of the 10th Annual Conference, Western Section, of The Wildlife Society (pp. 19-26).

Hall, D. J. (1980a). A comparison of population estimation methods for western gray squirrels. Unpublished manuscript, Pacific Gas and Electric, San Ramon, California. 
Hall, D. J. (1980b). Geysers Wildlife Investigations: Western gray squirrels (Report 420-79.132). Unpublished manuscript, Pacific Gas and Electric, San Ramon, Califomia.

Hall, E. R. (1981). The mammals of North America (2nd ed., Vol. 1). New York: John Wiley \& Sons.

Hall, J. G. (1981). A field study of the Kaibab squirrel in Grand Canyon National Park. Wildlife Monographs, 75, 1-54.

Hench, J. E., Kirkland, G. L., Jr., Setzer, H. W., \& Douglass, L. W. (1984). Age classification for the gray squirrel based on eruption, replacement and wear of molariform teeth. Journal of Wildlife Management, 48, 1409-1414.

Hitchcock, C. L., \& Cronquist, A. (1973). Flora of the Pacific Northwest. Seattle: University of Washington Press.

Ingles, L. G. (1947). Ecology and life history of the California gray squirrel. California Fish and Game, 33(3), 139-158.

Keith, J. O. (1965). The Abert squirrel and its dependence on ponderosa pine. Ecology, 46(1 \& 2), 150-163.

Livezely, B. C., \& Verts, B. J. (1979). Estimates of age and age structure in mazama pocket gophers: Thomomys mazama. The Murrelet, $\underline{60}, 38-41$.

Lord, R. D., Jr. (1959). The lens as an indicator of age in cottontail rabbits. Journal of Wildlife Management, 23 , 358-360.

Maser, C., Mate, B. R., Franklin, J. F., \& Dyrness, C. T. (1981). Natural history of Oregon Coast mammals (General Technical Report No. PNW-133). Washington, DC: U.S. Department of Agriculture, Forest Service.

Maser, C., Trappe, J. M., \& Nussbaum, R. A. (1978). Fungal-small mammal interrelationships with emphasis on Oregon coniferous forests. Ecology, 59, 799-809.

Maser, C., Trappe, J. M., \& Ure, D. C. (1978). Implications of small mammal mycophagy to the management of western coniferous forests. Proceedings of the North American Wildlife and Natural Resources Conference, $\underline{43}, 78-88$.

Maser, Z., Maser, C., \& Trappe, J. M. (1985). Food habits of the northern flying squirrel (Glaucomys sabrinus) in Oregon. Canadian Journal of Zoology, 63, 1084-1358. 
McComb, W. C., \& Noble, R. E. (1981). Nestbox and natural cavity use in three mid-south forest habitats. Journal Wildlife Management, 45(1), 93-101.

McIntire, P. W. (1984). Fungus consumption by the Siskiyou chipmunk within a variously treated forest. Ecology, 65(1), 137-146.

Miller, K. (1984). Draft habitat suitability index model western gray squirrel (Sciurus griseus). Sacramento, CA: U.S. Fish and Wildlife Service, Division of Ecological Services.

Nellis, C. H. (1969). Sex and age variation in red squirrel skulls from Missoula County, Montana. The Canadian Field-Naturalist, 83(4), 324-330.

Nichols, J. T. (1958). Food habits and behavior of the gray squirrel. Journal of Mammology, 39(3), 376-380.

Park, E. (1983, September). Hunt for silver. Field \& Stream, pp. 140-141.

Patton, D. R. (1984). A model to evaluate Abert squirrel habitat in uneven-aged ponderosa pine. Wildlife Society Bulletin, 12(4), 408-414.

Patton, D. R., Wadleigh, R. L., \& Hudak, H. G. (1985). The effect of timber harvesting on the Kaibab squirrel. Joumal of Wildlife Management, $49(1)$, 14-19.

Pederson, J. C., Hasenyager, R. N., \& Heggenet, A. W. (1976). Habitat requirements of the Abert squirrel (Sciurus aberti navajo) on the Monticello District. Manti-LaSal National Forest of Utah (Publication No. 76-9). Salt Lake City: Utah Division of Wildlife Resources.

Peterson, R. T. (1990). A field guide to Western birds. Boston: Houghton Mifflin.

Petrides, G. A. (1951). Analysis of gray squirrel breeding studies and their relation to hunting season, gunning pressure, and habitat conditions. Transactions of the 18th North American Wildlife Conference (pp. 378-389), March 9-11, 1983.

Pocock, R. I. (1923). The classification of the sciuridae. Proceedings of the Zoological Society of London, 209-246.

Robinson, W. L., \& Bolen, E. G. (1989). Wildlife ecology and management (2nd ed.). New York: Macmillan. 
Rodrick, E. A. (1987). Survey of historic habitats of the western gray squirrel (Sciurus griseus) in the southern Puget Trough and Klickatat County Washington. Unpublished master's thesis, University of Washington, Seattle.

Seton, E. T. (1928). Life LXIII-California gray squirrel. The lives of game animals (Vol. 4, pp. 59-66). New York: Doubleday Doran.

Sharp, L. (1985). Habitat suitability index model for the western gray squirrel. Sacramento, CA: U.S. Fish and Wildlife Service.

Sharp, W. M. (1958). Aging gray squirrel by use of tail pelage characteristics. Joumal of Wildlife Management, $\underline{22}(1), 29-34$

Smith, C. C. (1970). The coevolution of pine squirrels (Tamiasciurus) and conifers. Ecological Monographs, $\underline{40}, 349-371$.

Stienecker, W. F. (1977). Supplemental data on the food habits of the western gray squirrel. California Fish and Game, 63(1), 11-21.

Stienecker, W. F., \& Browning, B. M. (1970). Food habits of the western gray squirrel. California Fish and Game, 56(1), 36-48.

Sullins, G. L., McKay, D. O., \& Verts, B. J. (1976). Estimating ages of cottontails by periosteal zonations. Northwest Science, $\underline{50}(1), 17-22$.

Swift, R. J. (1977). The reproductive cycle of the western gray squirrel in Butte County, California. Unpublished mastei's thesis, California State University, Chico.

Topik, C., Halverson, N. M., \& High, T. (1988). Plant association and management guide for the ponderosa pine, Douglas-fir, and grand fir zones: Mt. Hood National Forest (No. R6-ECOL-TP-004-88). Washington, DC: U.S. Department of Agriculture, Forest Service, Pacific Northwest Region.

U.S. Department of Agriculture, U.S. Forest Service. (1965). Oregon white oak (Quercus garryana Dougl). Silvics of Forest Trees of the United States (Agriculture Handbook No. 271, pp. 596-598). Washington, DC: Author.

Vahle, J. R., \& Patton, D. R. (1983). Red squirrel cover requirements in Arizona mixed conifer forests. Journal of Forestry, January, pp. 14-22.

Wade, O., \& Gilbert, P. O. (1940). The baculum of some sciuridae and its significance in determining relationships. Journal of Mammalogy, 21, 52-63. 


\section{ADDITIONAL LITERATURE}

Cross, S. P. (1960). Gray squirrel taxonomy and distribution in San Luis Obispo County, California. Unpublished manuscript, California State Polytechnic College, San Luis Obispo.

Cross, S. P. (1968). A report on present status of western gray squirrel management. Unpublished manuscript.

Dalquist, W. W. (1948). Mammals of Washington. Lawrence, KA: University of Kansas Publications.

Evans, R. H. (1984). Ivermectin treatment of notoedric mange in two fox squirrels. Joumal of American Veterinary Medicine Association, 185, 1437-1438.

Farentinos, R. C., Capretta, P. J., Kepner, R. E., \& Littlefield, V. M. (1981). Selective herbivore in tassel-eared squirrels: Role of monoterpenes in ponderosa pines chosen as feeding trees. Science, 213, 1273-1275.

Fletcher, R. A. (1963). The ovarian cycle of the gray squirrel, Sciurus griseus nigripes. Unpublished master's thesis, University of California, Berkeley.

Fry, M. E., Burchan, D., \& Hall, D. J. (1980). An improved handling procedure for live-trapped squirrels. Unpublished manuscript, Pacific Gas and Electric Company, San Ramon, California.

Gross, D. C. (1983). Western gray squirrel sighting records on and adjacent to the Barlow Ranger District and some tentative conclusions-1982. Unpublished manuscript.

Gurnell, J. (1983). Squirrel numbers and the abundance of tree seeds. Mammal Review, 13(2/3/4), 133-148.

Hafner, D. J. (1984). Evolutionary relationships of the nearctic Sciuridae. In J. O. Murie \& G. R. Michener (Eds.), The biology of ground dwelling squirrels. Lincoln, NE: University of Nebraska Press.

Ingles, L. G. (1965). Mammals of the Pacific states. Stanford, CA: Stanford University Press.

Kenward, R. (1987). Wildlife radio tagging: Equipment, field techniques and data analysis. New York: Academic Press. 
Kotter, M. M., \& Farentinos, R. C. (1984). Tassel-eared squirrels as spore dispersal agents of hypogeous mycorrhizal fungi. Joumal of Mammalogy, 65, 684-687.

MacClintock, D. (1970). Squirrels of North America. New York: Van Nostrand Reinhold Company.

Moore, J. C. (1961). The spread of existing diumal squirrels across the Bering and Panamanian land bridges. American Museum Novitiates, 2044, 1-26.

Nixon, C. M., Havera, S. P., \& Hansen, L. P. (1980). Initial response of squirrels to forest changes associated with selection cutting. Wildlife Society Bulletin 8(4), 298-306.

Nixon, C. M., McClain, M. W., \& Donohoe, R. W. (1980). Effects of clearcutting on gray squirrels. Journal of Wildlife. Management, 44(2), 403-412.

Shimamoto, K., \& Airola, D. (1981). Fish and wildlife habitat capability models and special criteria for the northeast zone national forests. Washington, DC: U.S. Department of Agriculture, Forest Service.

Soil Conservation Service. (1980). Habitat suitability index model-western gray squirrel. Unpublished manuscript, U.S. Fish and Wildlife Service, Ecoregion 2610, Central Valley.

Stephenson, R. L., \& Brown, D. E. (1977). Tree squirrel investigations (Project W53-R-27 Final Report). Phoenix: Arizona Game and Fish Department.

Trappe, J. M., \& Maser, C. (1976). Germination of spores of Glomus macrocarpus (Endogonaceae) after passage through a rodent digestive tract. Mycologia, $\underline{68}(2), 433-436$.

Trappe, J. M., \& Maser, C. (1977). Ectomycorrhizal fungi: Interactions of mushrooms and truffles with beasts and trees. In T. Walters (Ed.), Mushrooms and man: An interdisciplinary approach to mycology (pp. 165-179). Washington, DC: U.S. Department of Agriculture, Forest Service. Reproduced for official use.

U.S. Forest Service, Mt. Hood National Forest Pacific Northwest Region. (1988). Plant association and management guide for the ponderosa pine. Douglas-fir, and grand fir zones (Report No. R6-Ecol-TP-004-88). Portland, OR: Author. 
U.S. Forest Service. (1984). Plant association intensive plot instructions.

Unpublished manuscript, Area 7 Ecology Program, Mt. Hood and Gifford Pinchot National Forests.

Ure, D. C., \& Maser, C. (1982). Mycophagy of red-backed voles in Oregon and Washington. Canadian Journal of Zoology, 60, 3307-3315.

Williams, C. K., \& Winward, A. H. (1976). Plant community types of the Badger allotment. Unpublished manuscript, Barlow Ranger District, Mt. Hood National Forest. 


\section{APPENDIX A}

HUNTER COOPERATION PROGRAM

INFORMATION SHEET 


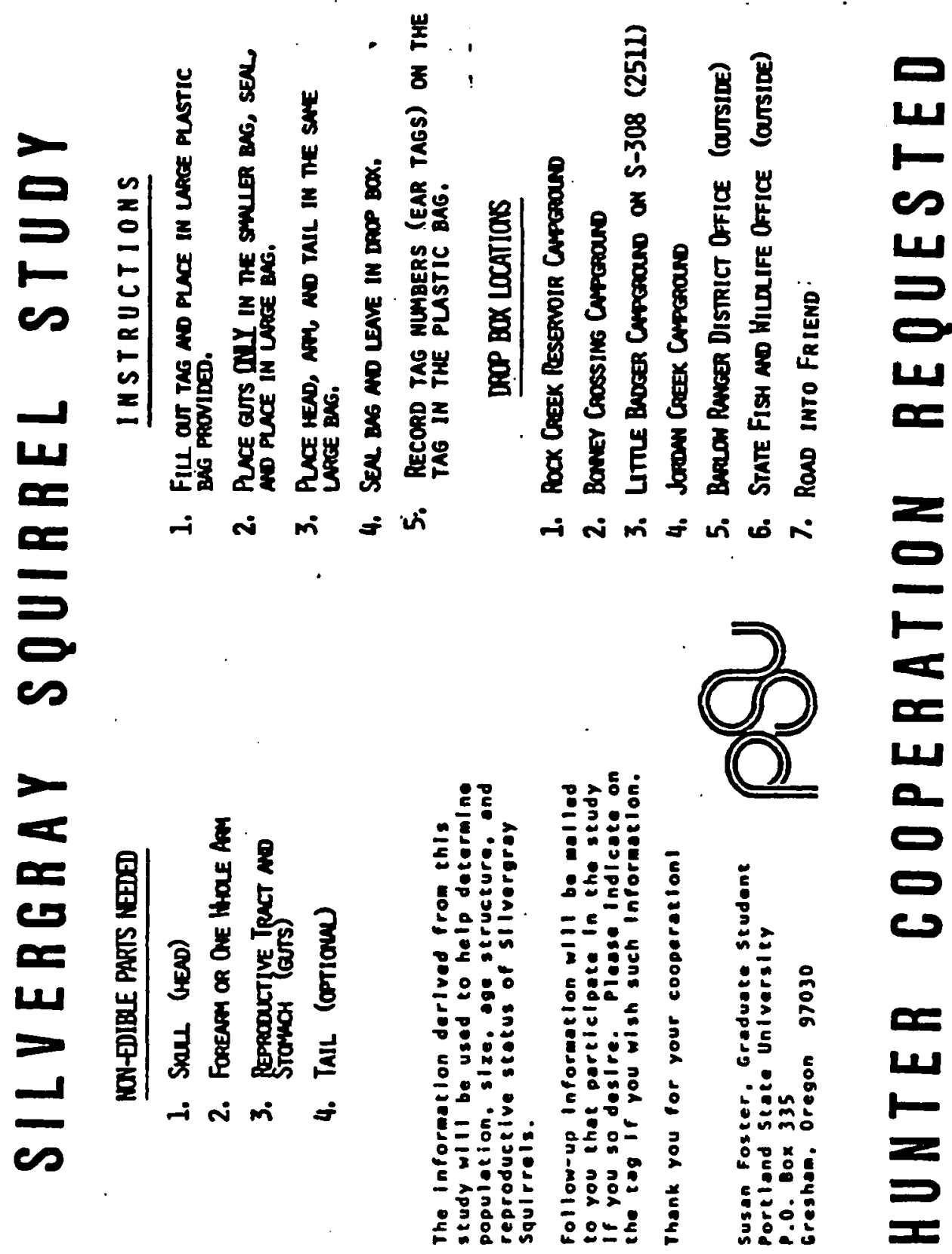




\section{APPENDIX B}

RAW DATA FROM HUNTER COOPERATION PROGRAM INCLUDING HUNTING SEASON ROADKILLS AND ANIMALS OBTAINED FROM OREGON DEPARTMENT OF FISH AND WILDLIFE AND OREGON STATE POLICE PERSONNEL

FOR STOMACH CONTENT ANALYSIS 


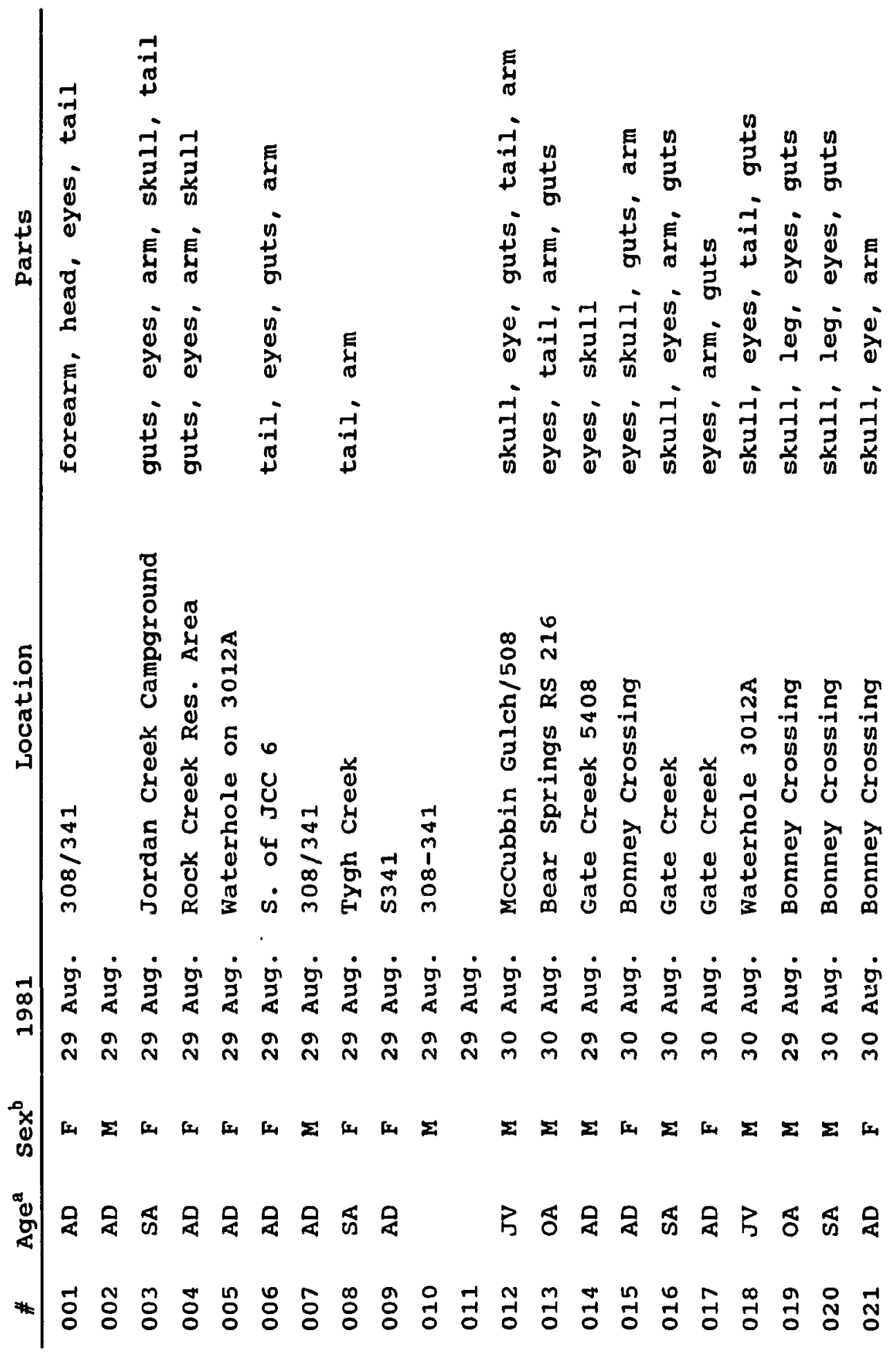




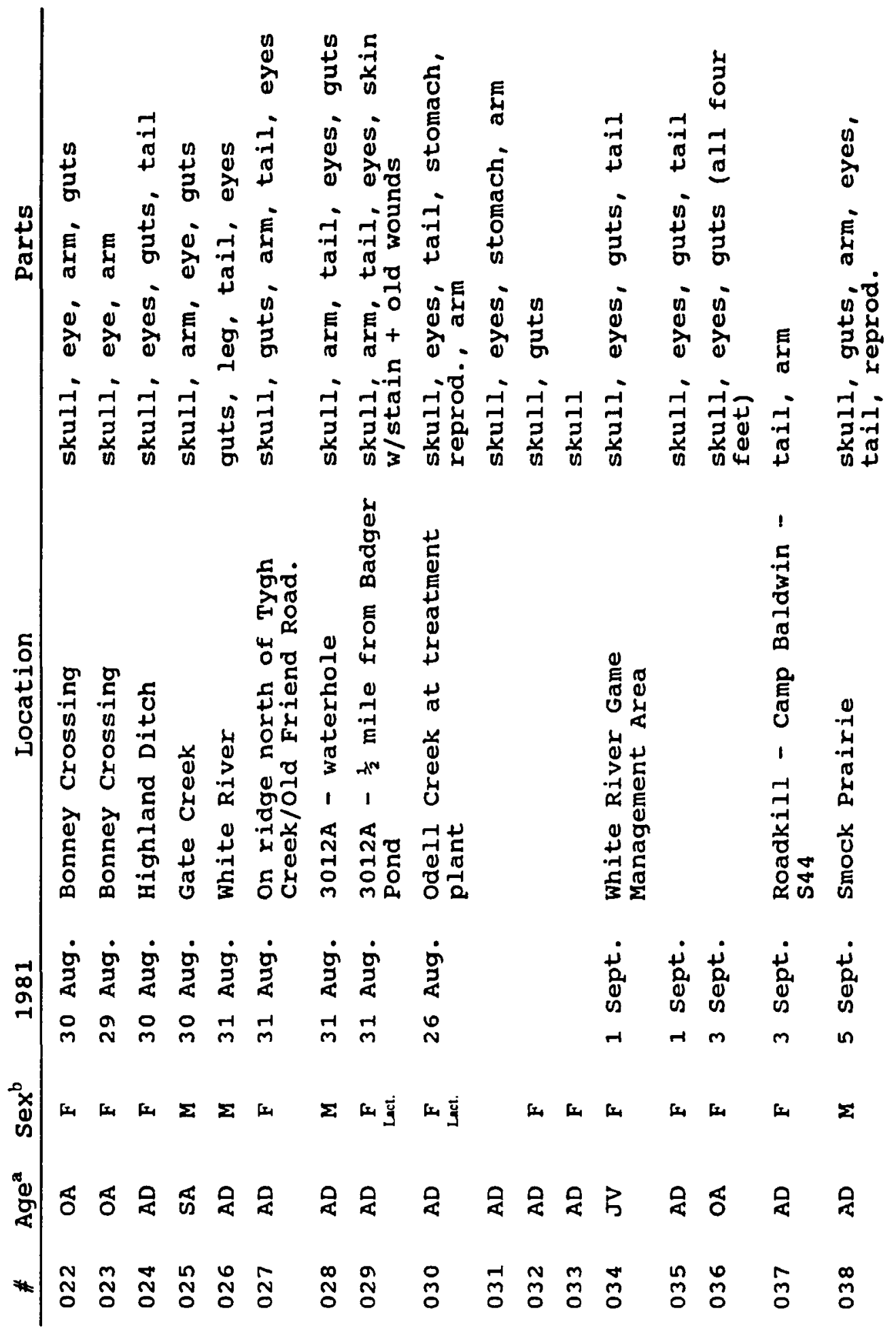




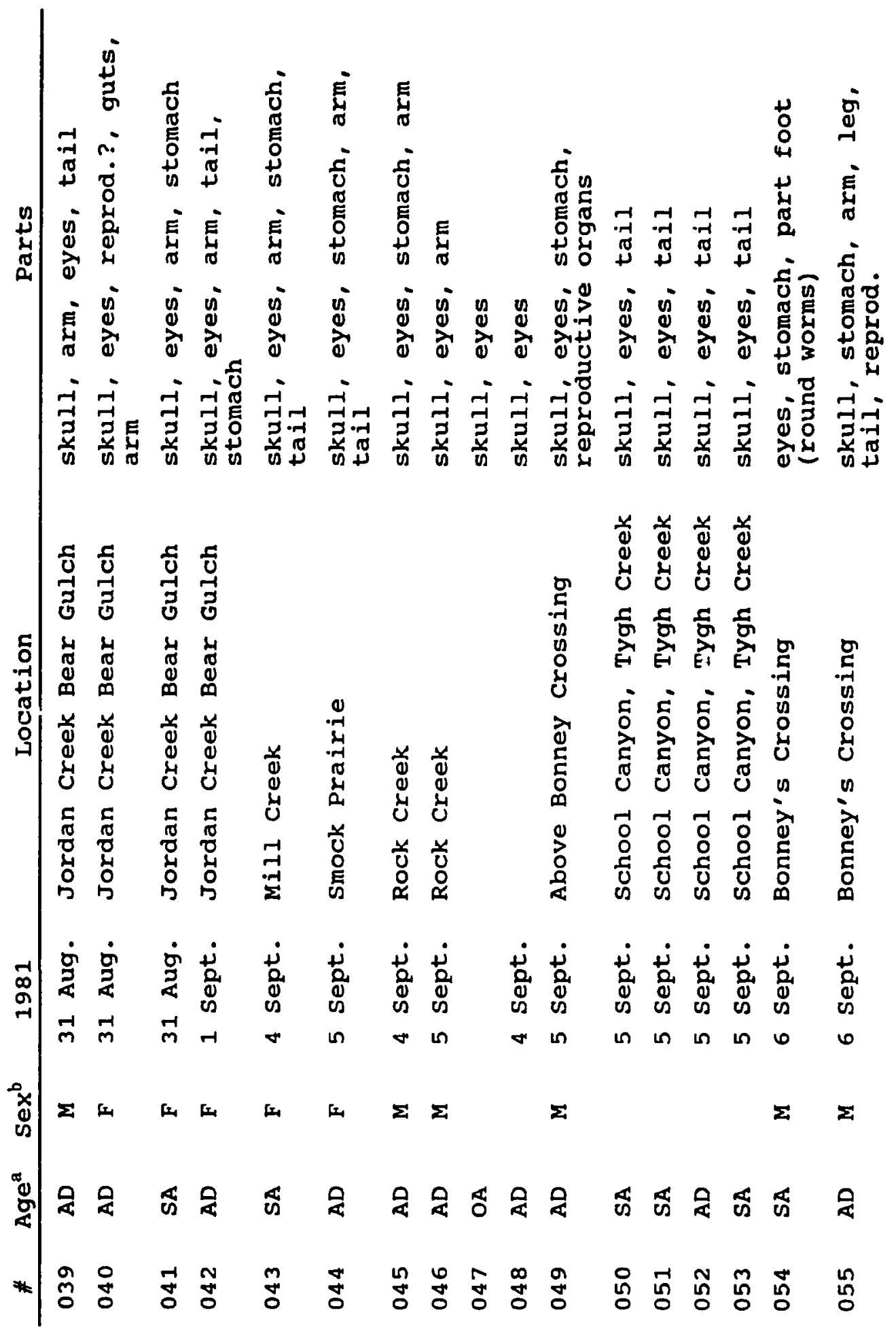




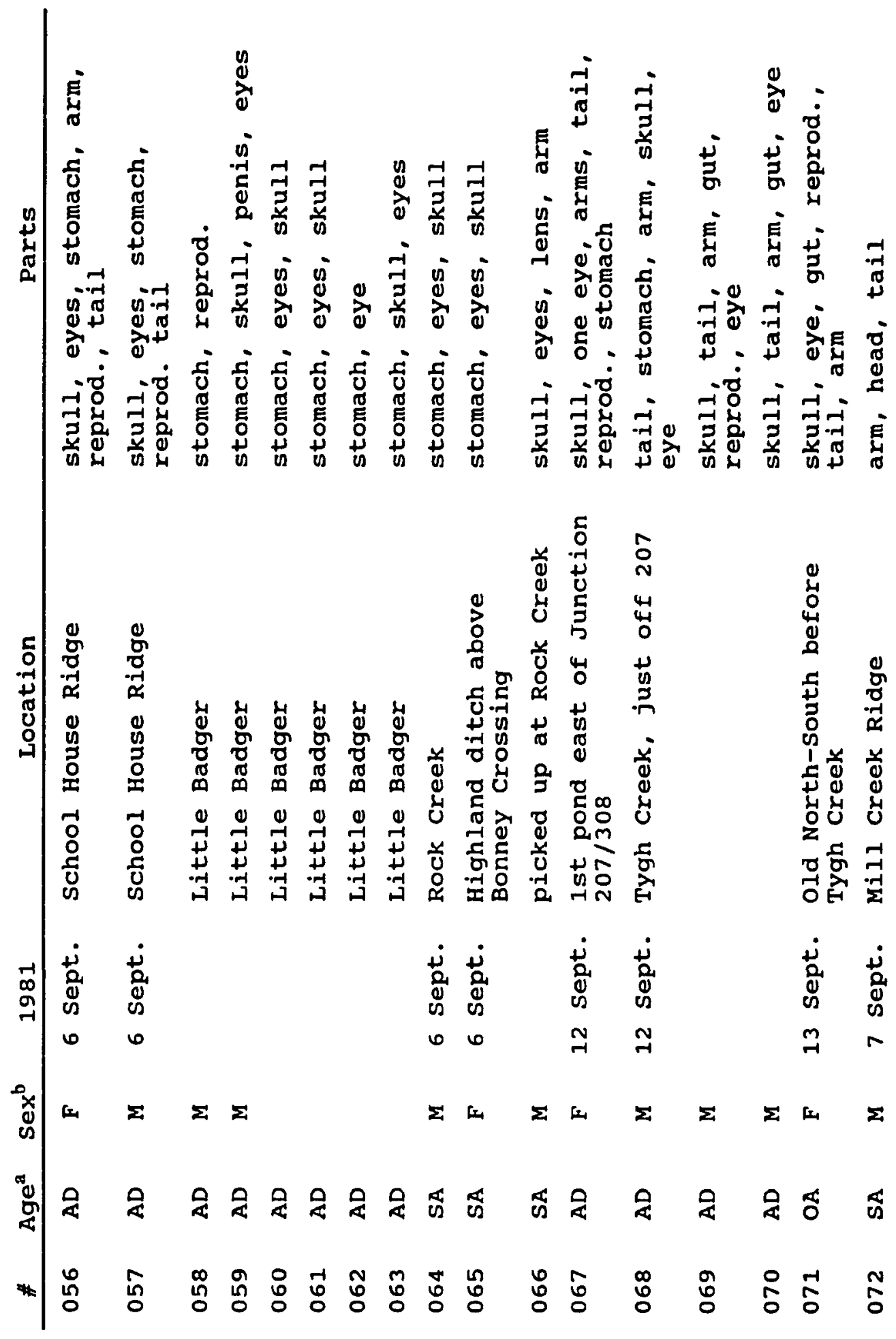




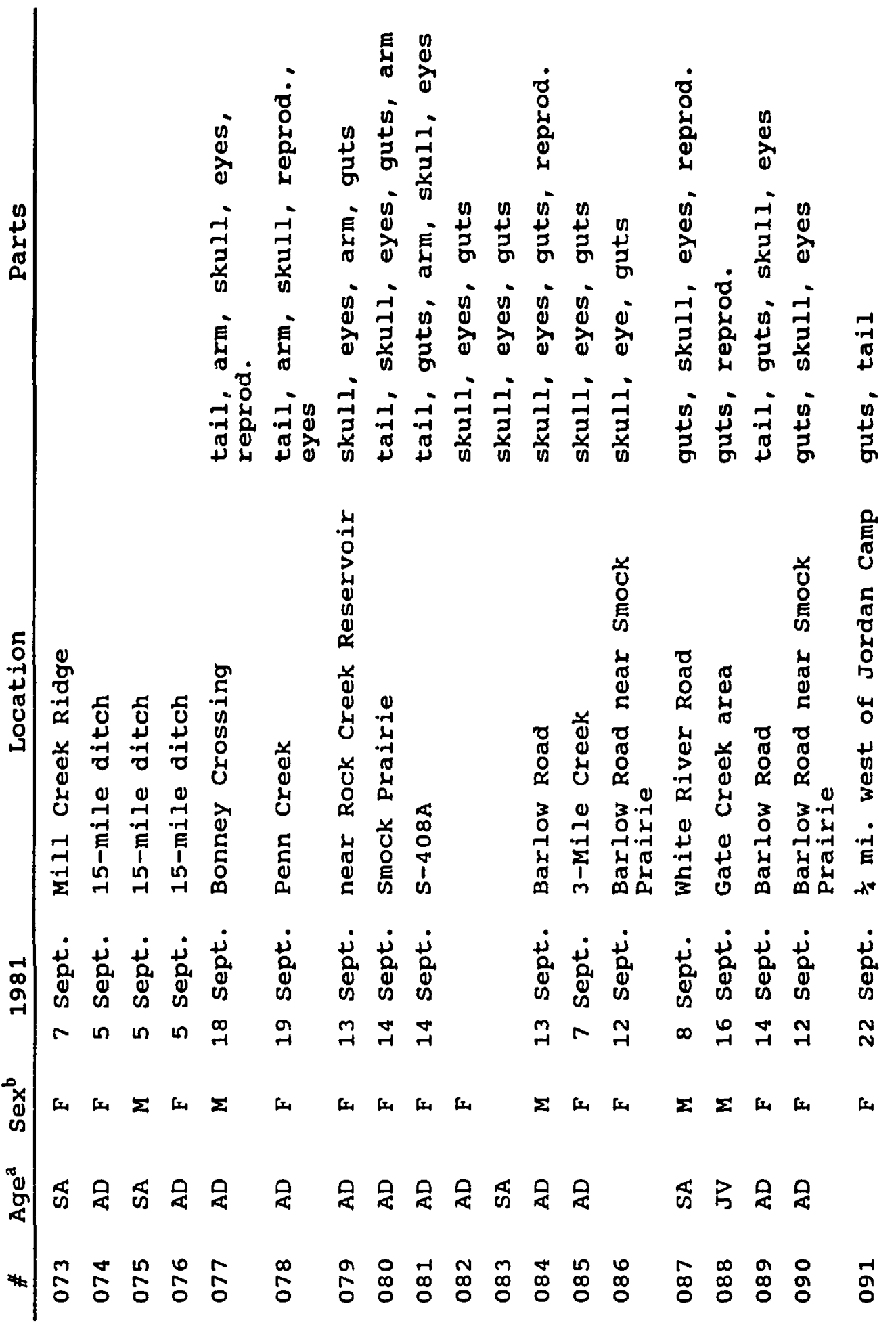




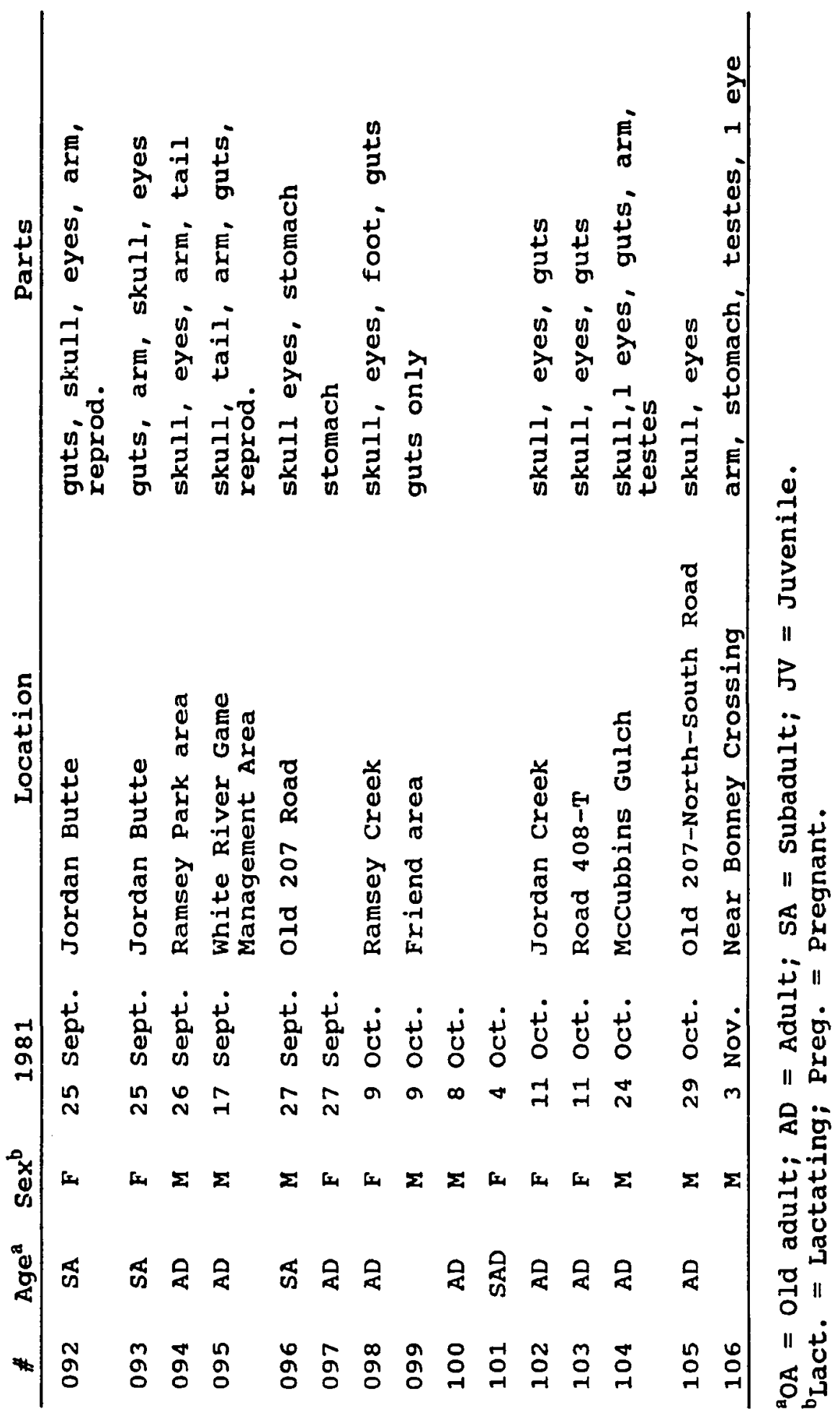




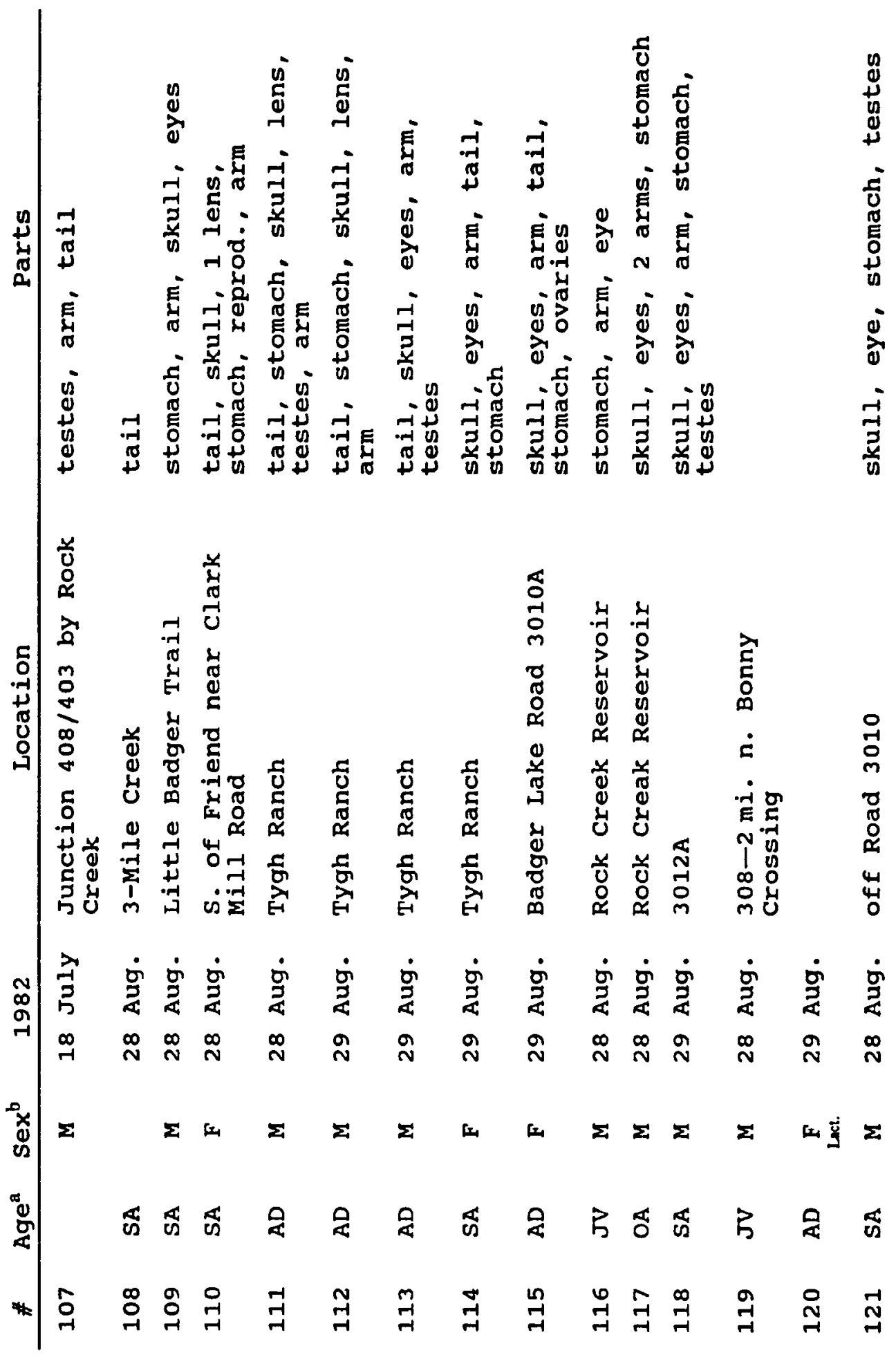




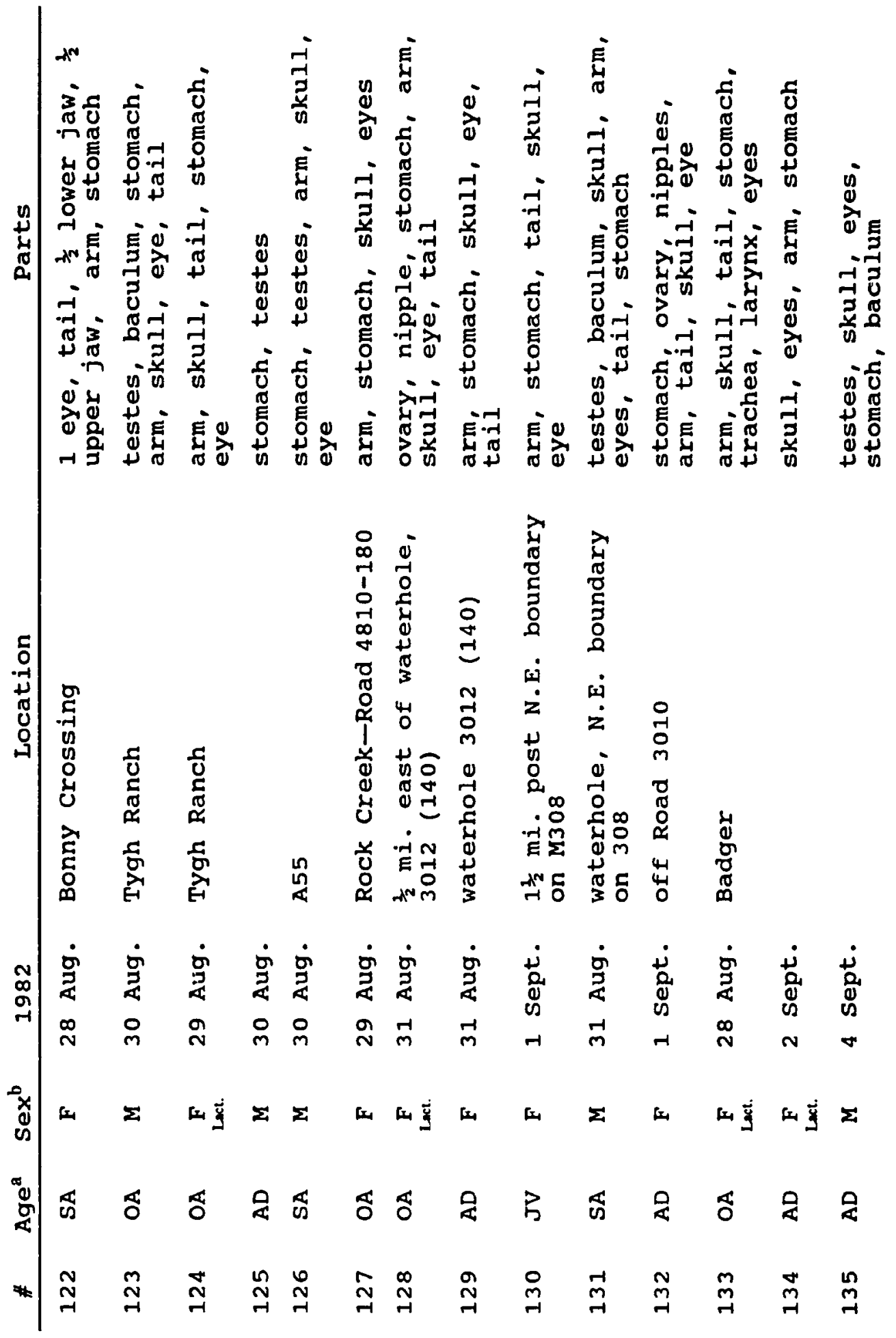




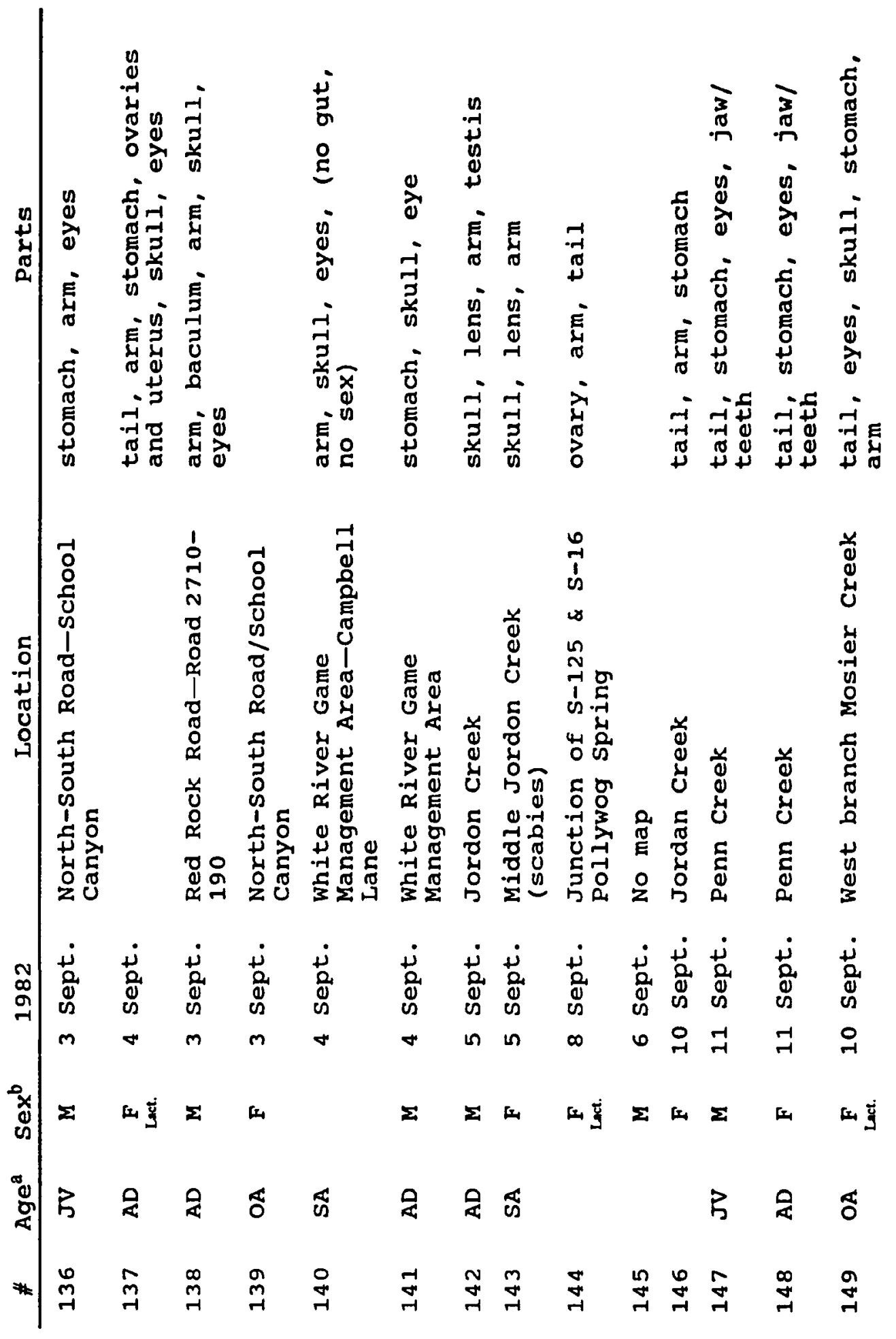




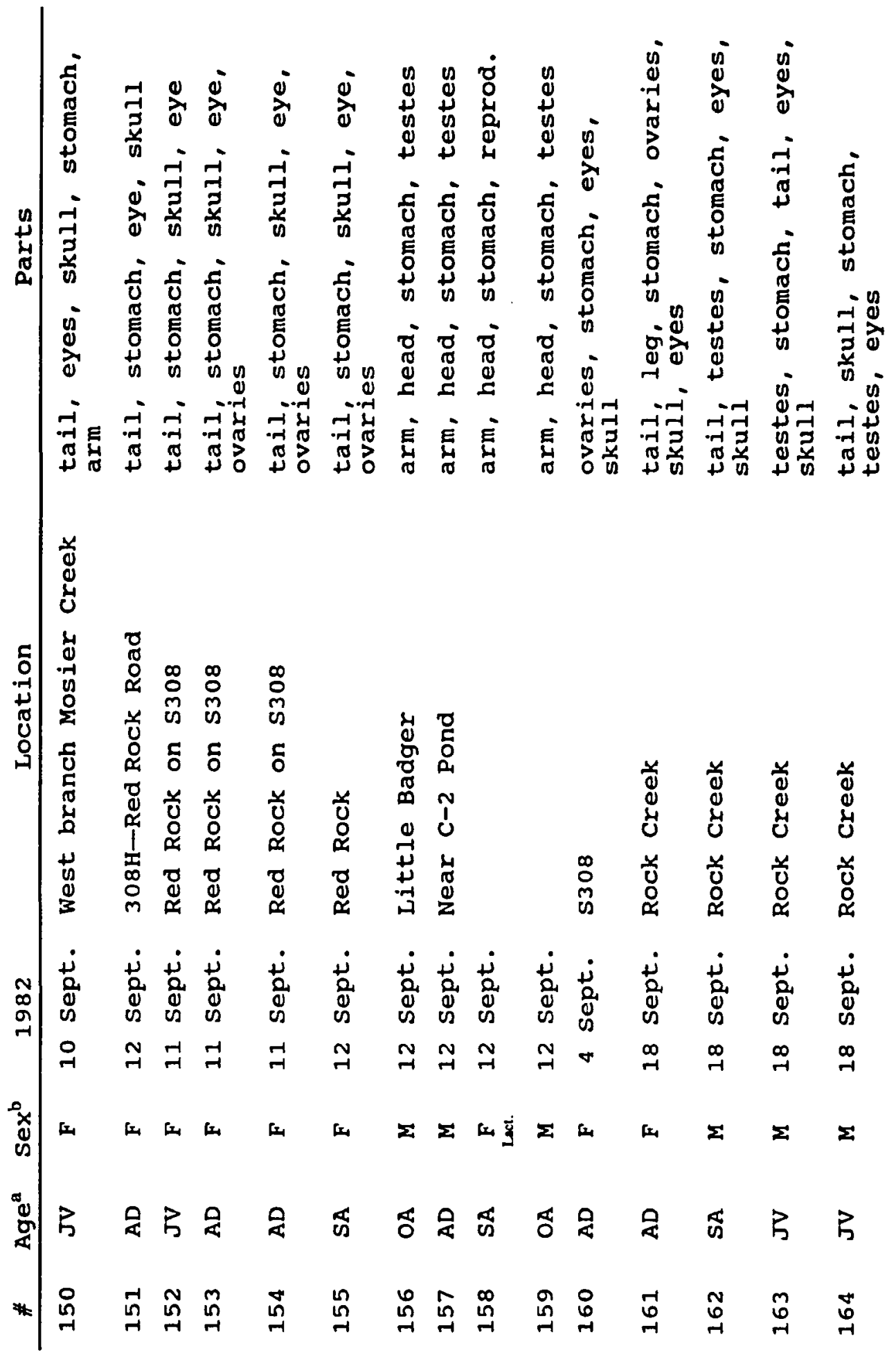




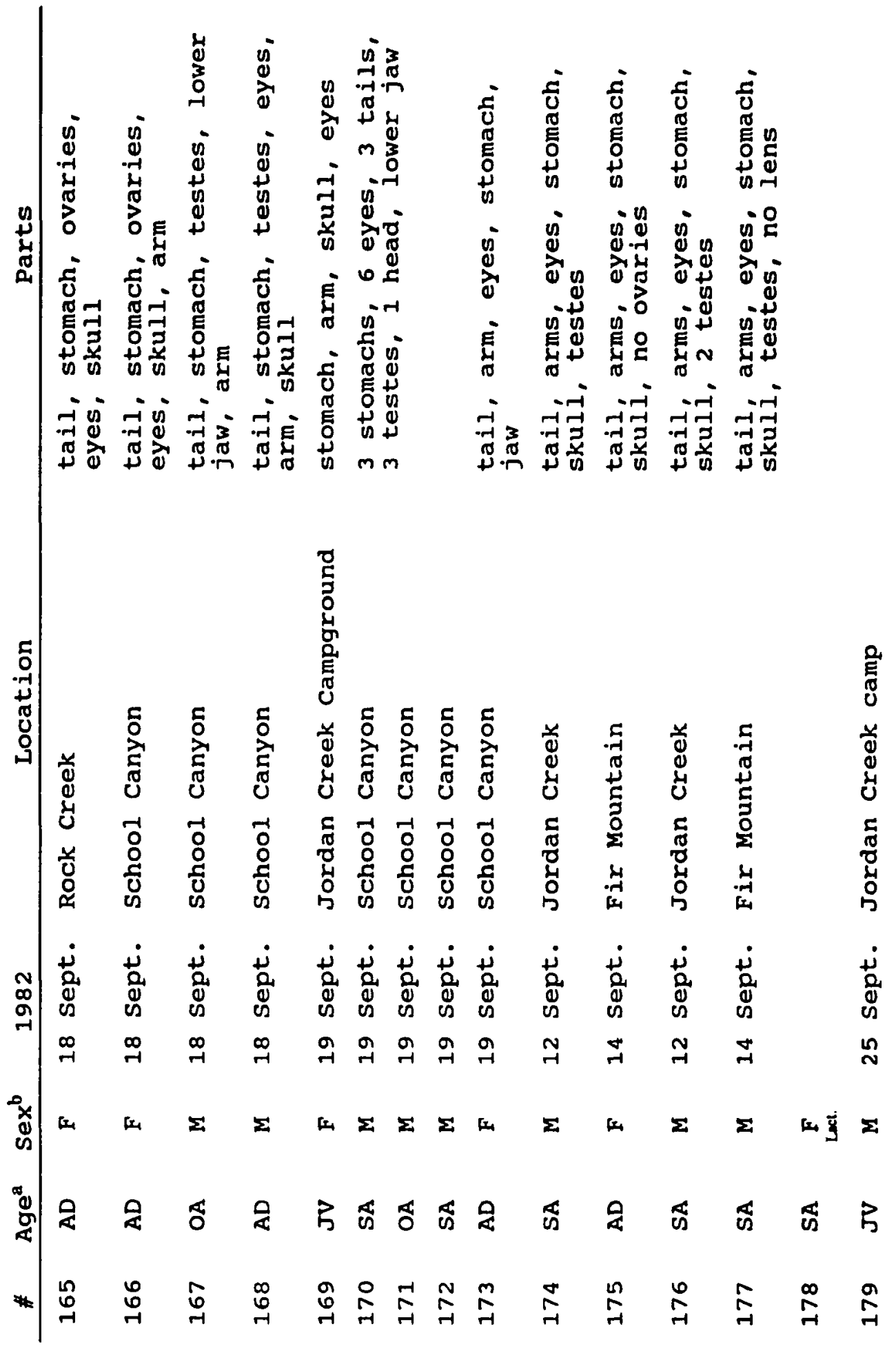




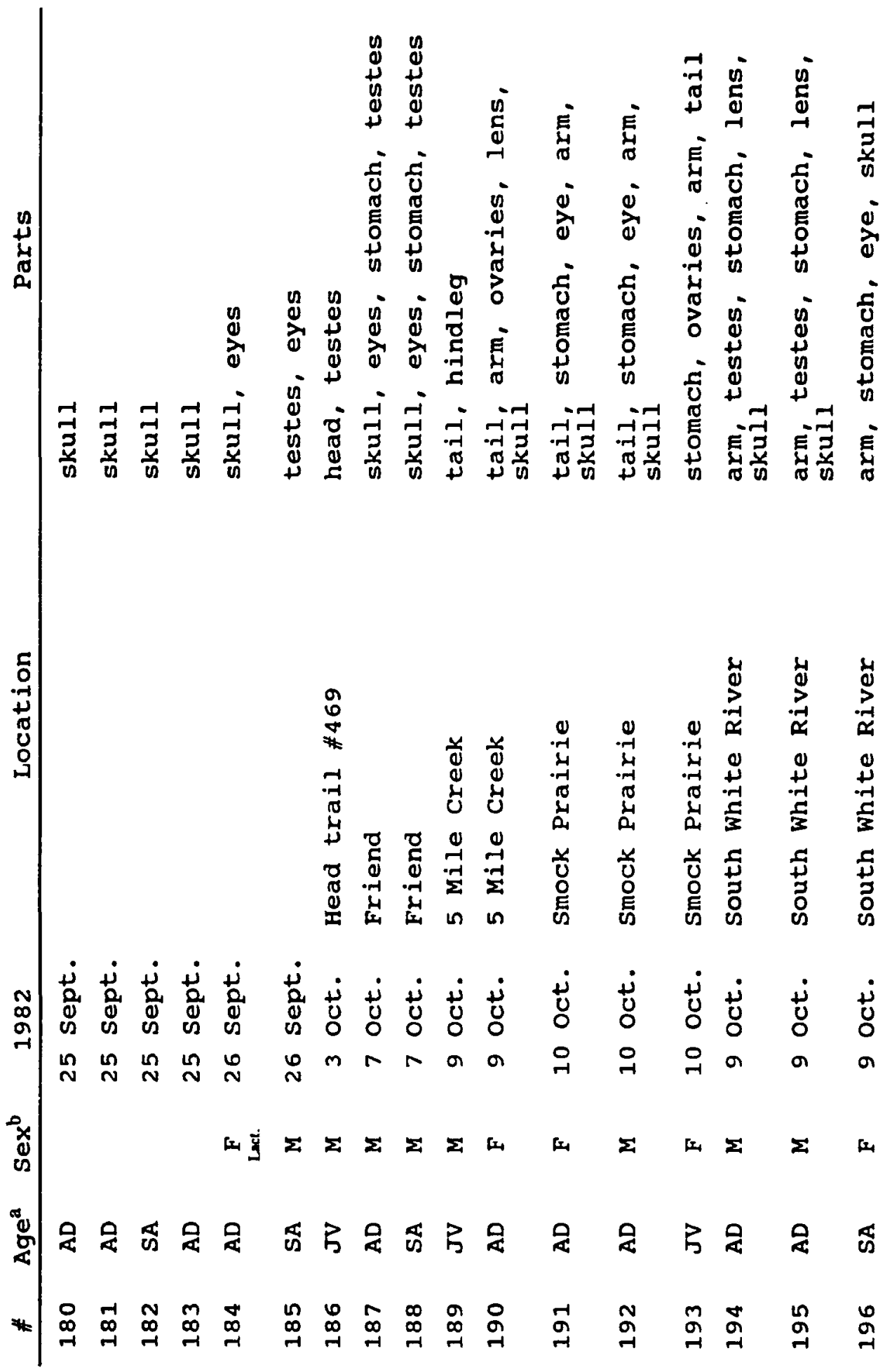




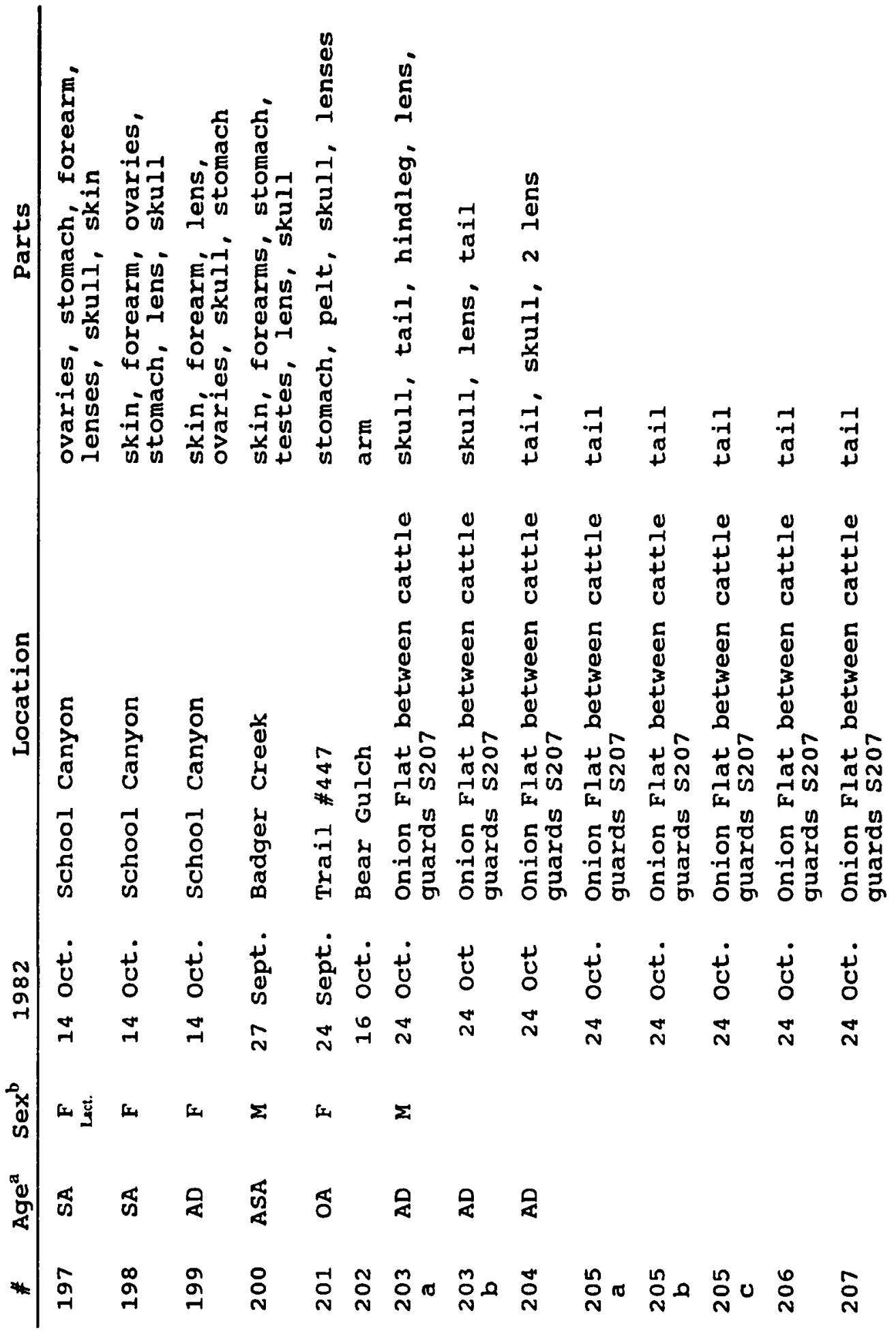




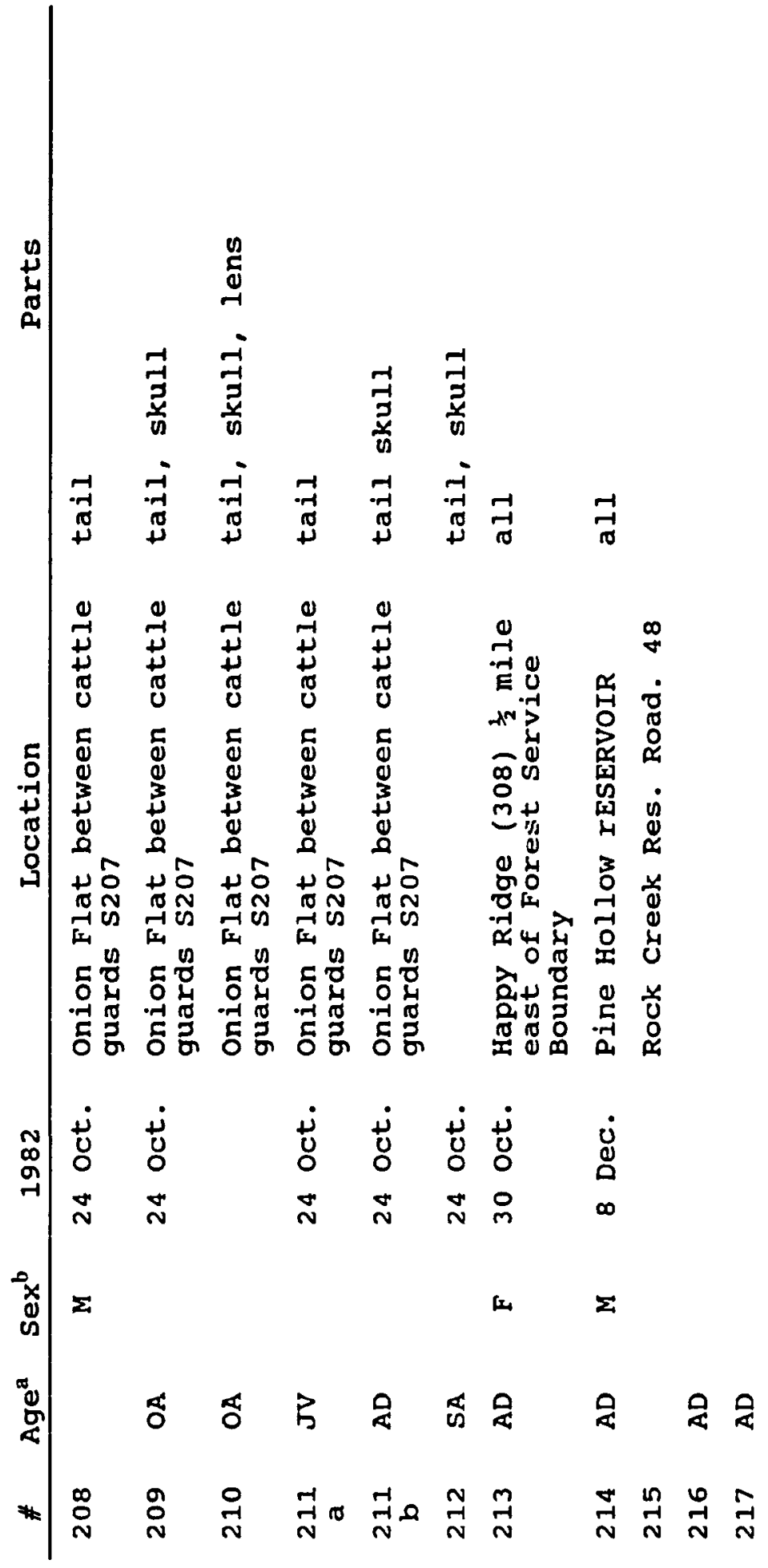




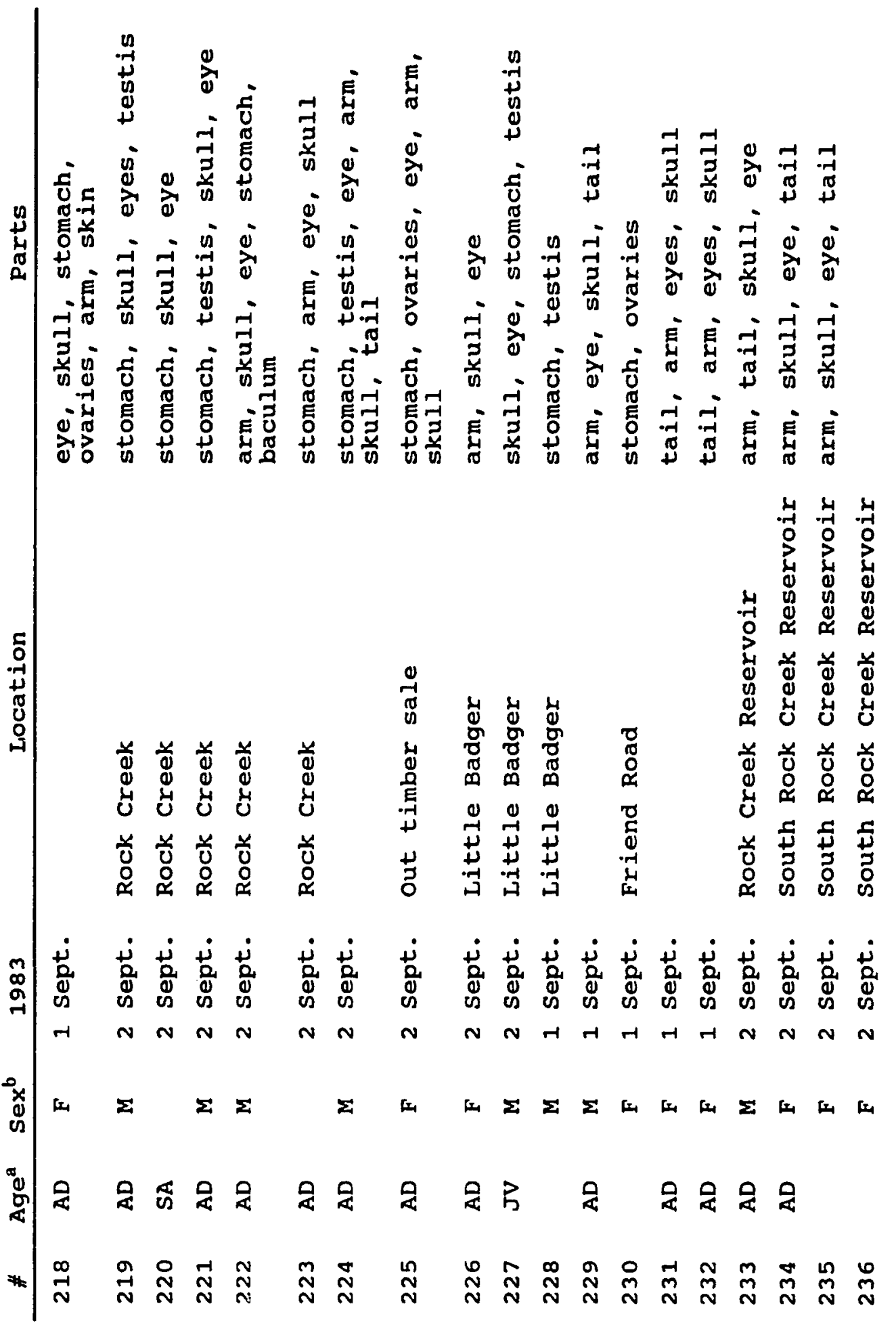




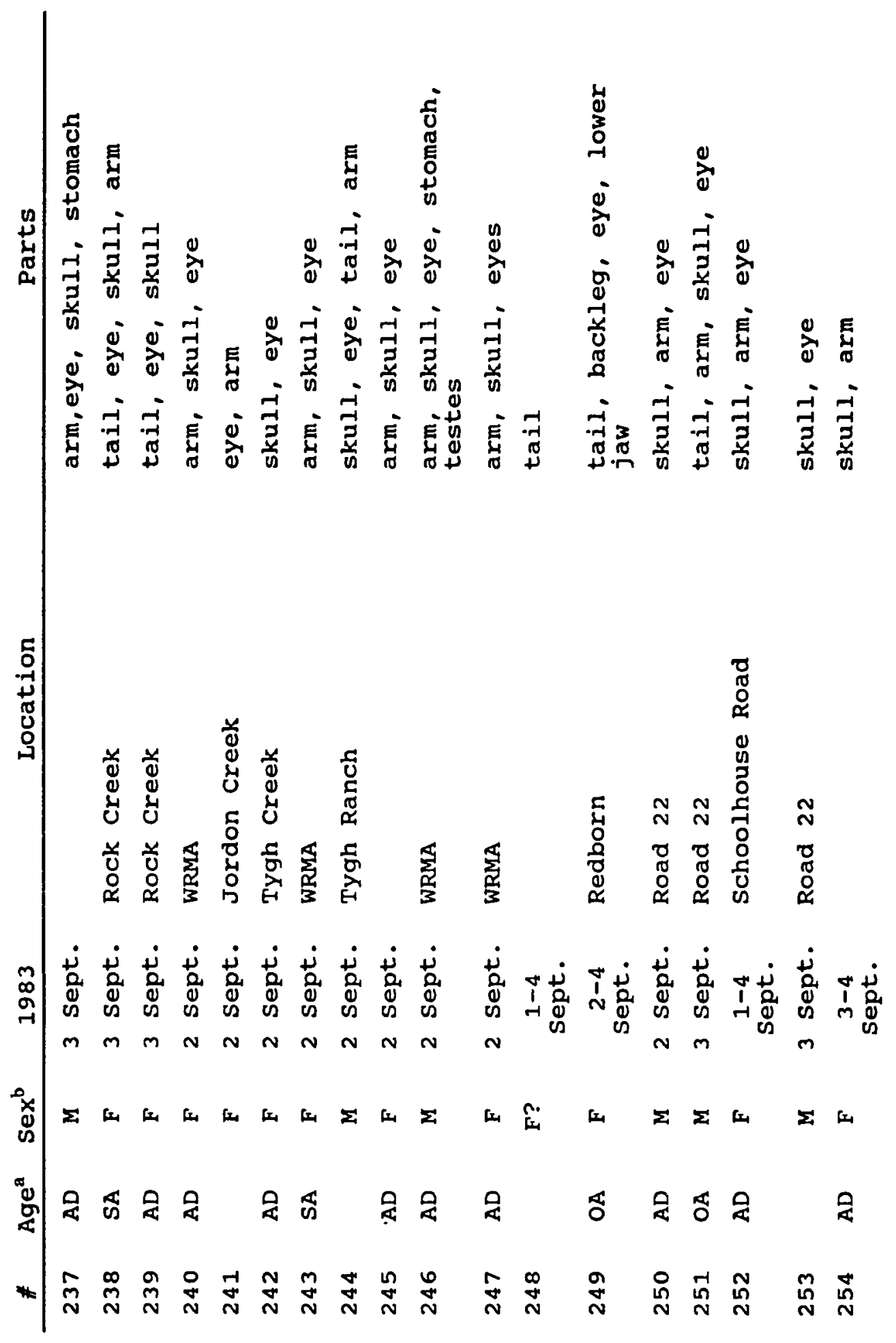




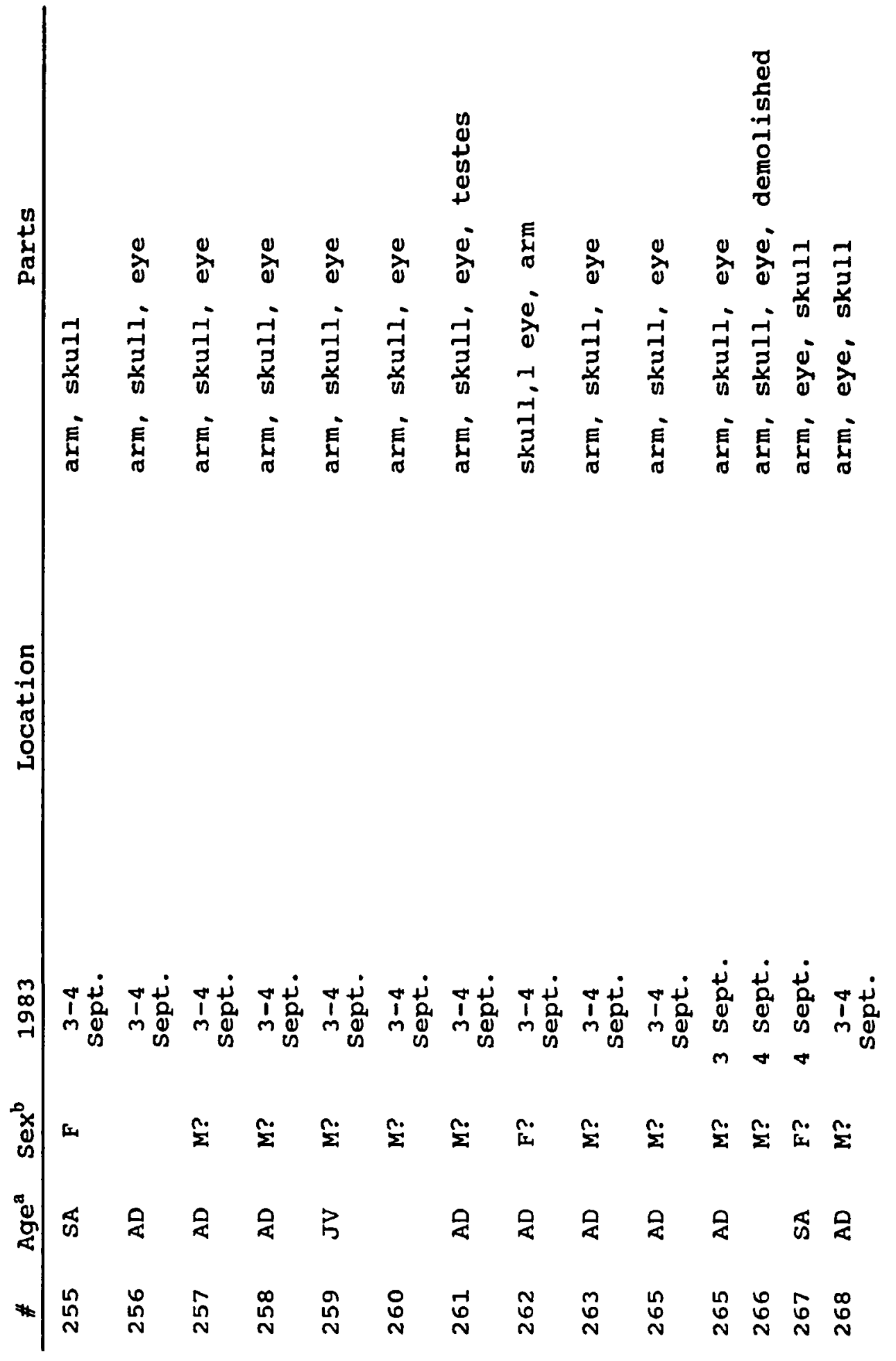




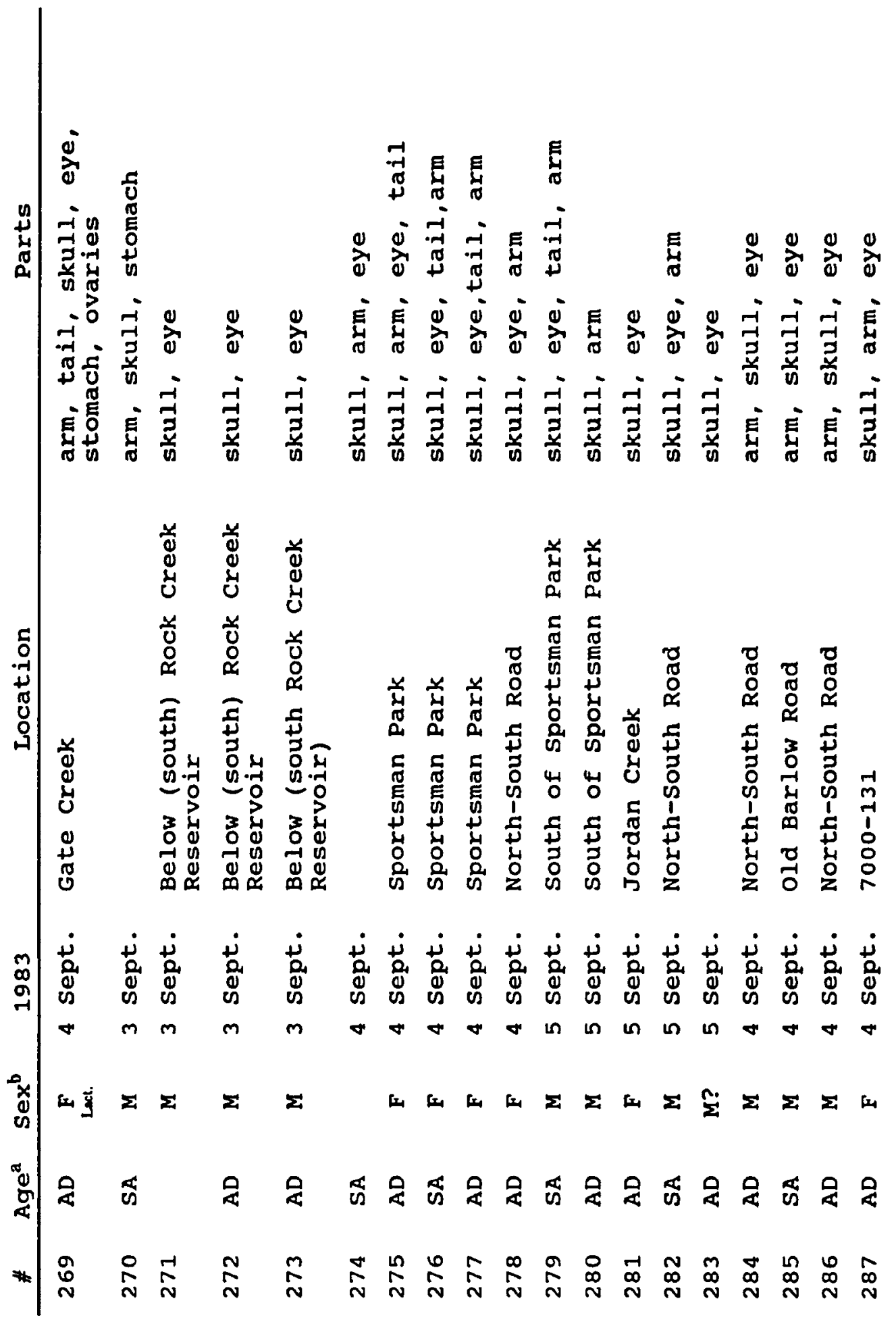



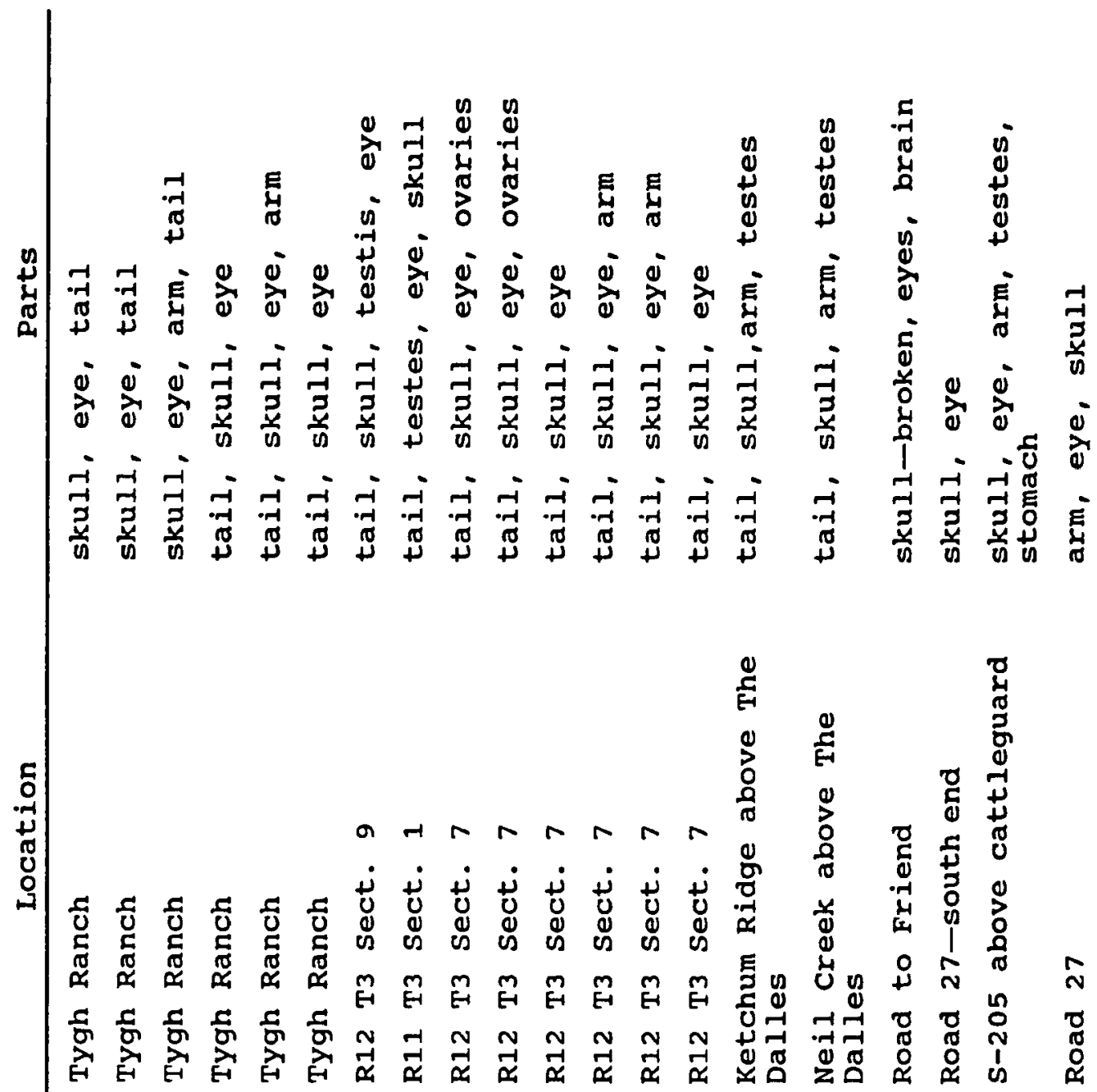

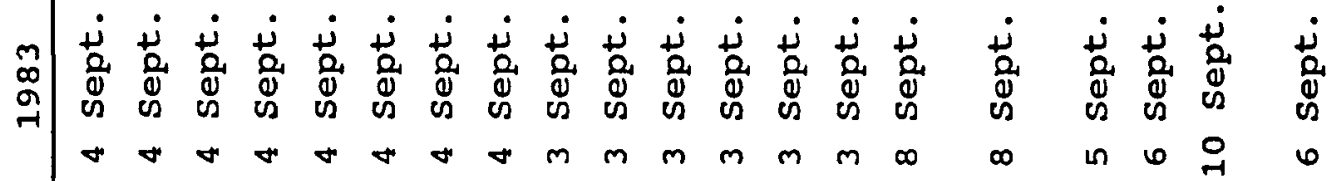

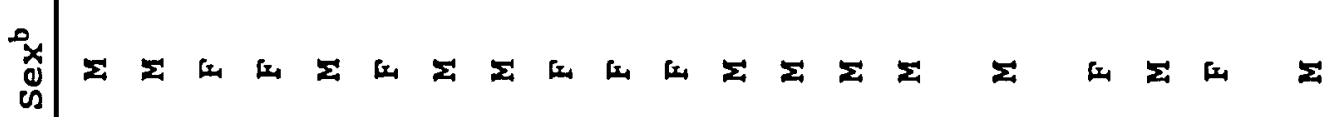

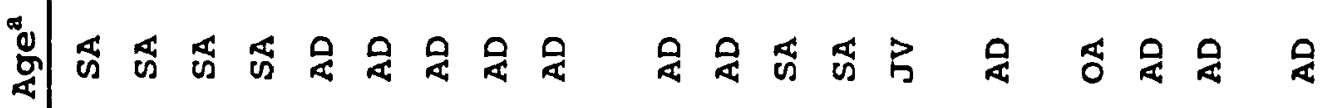

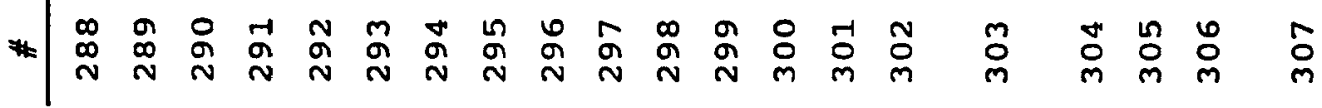




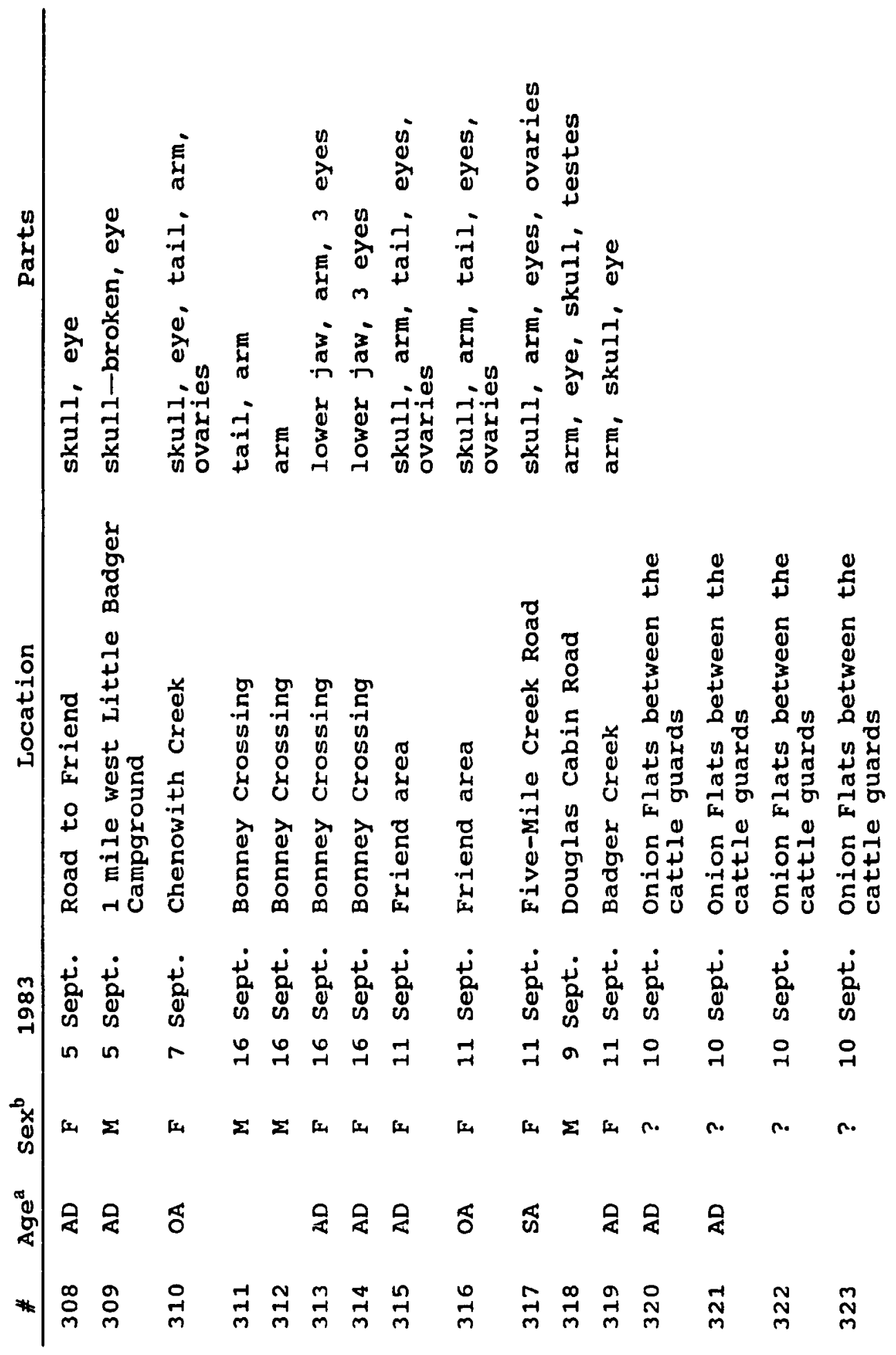




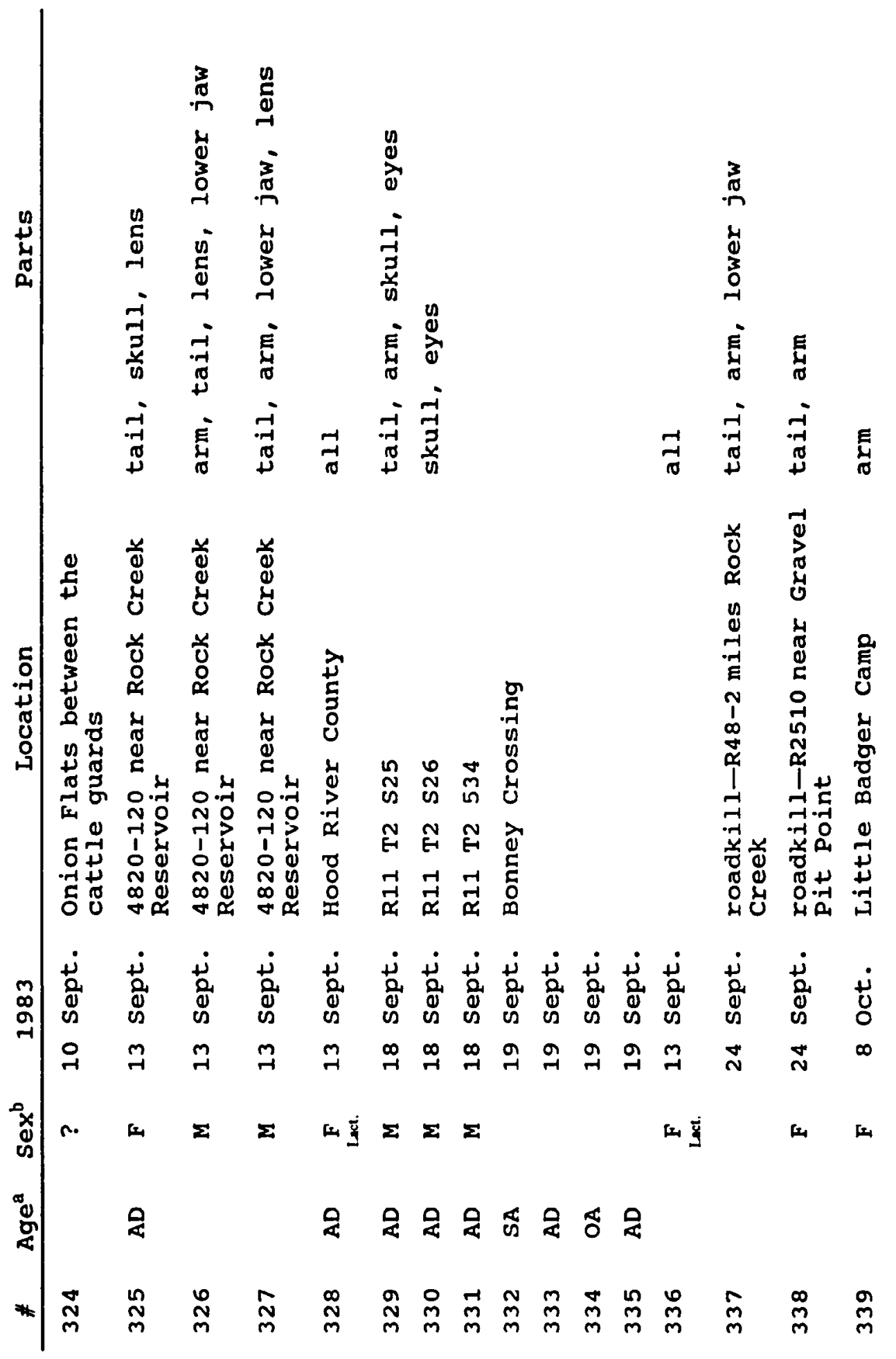




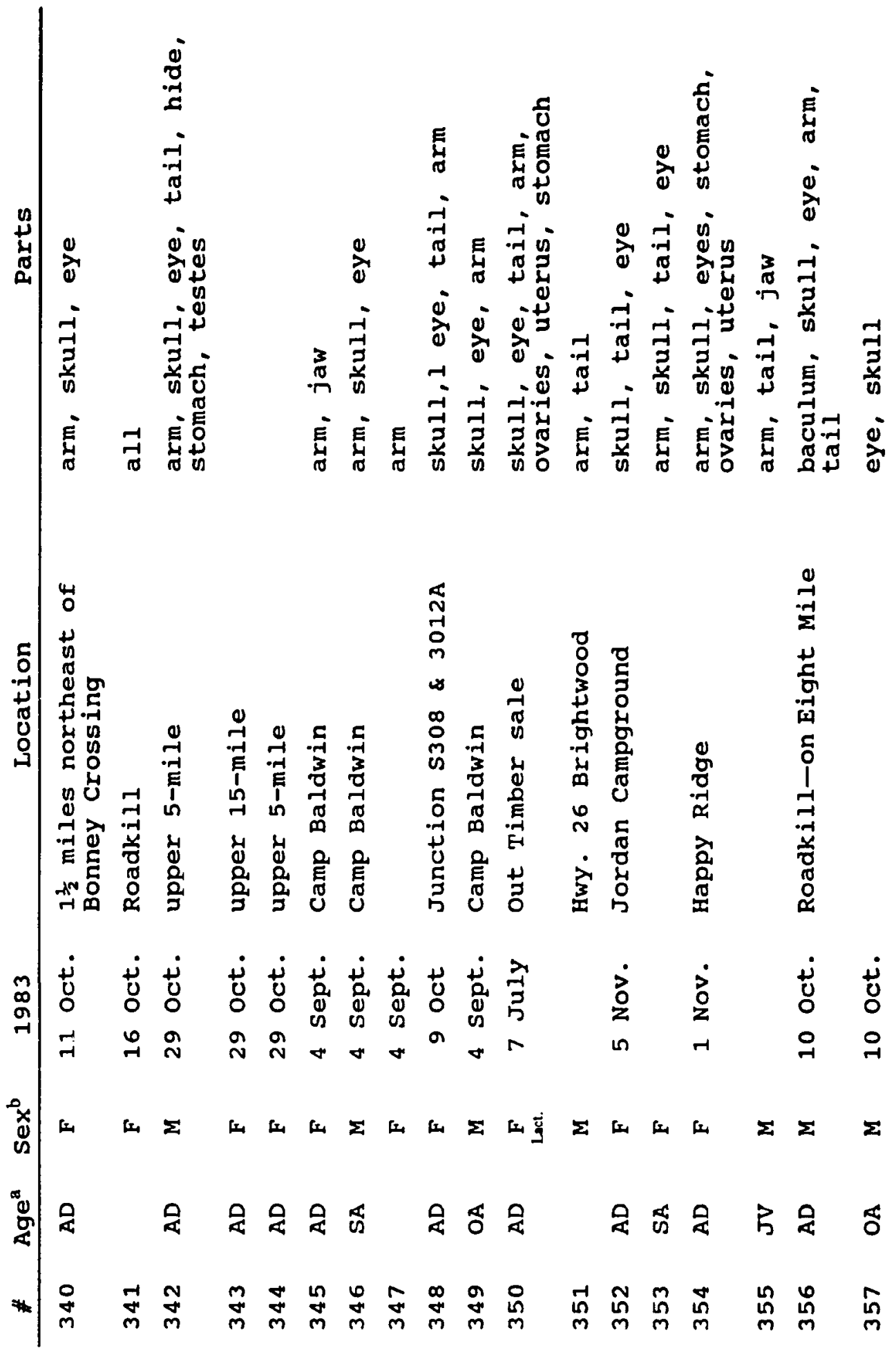




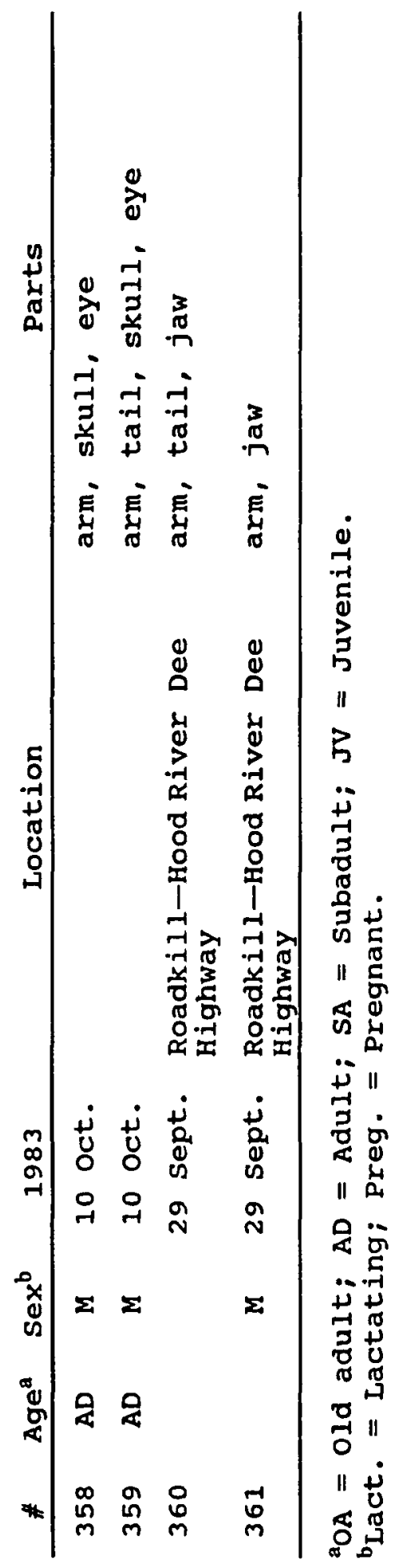




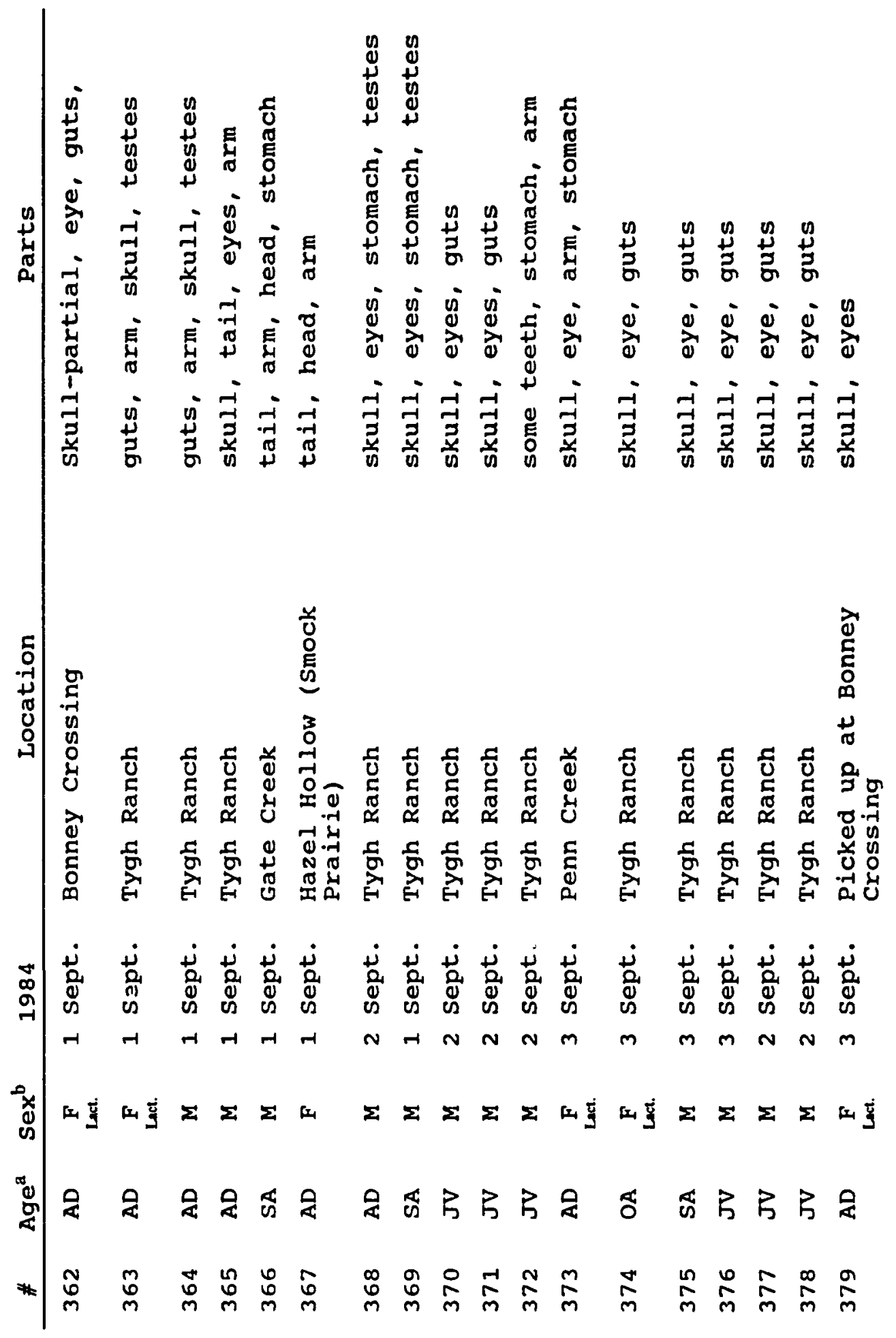




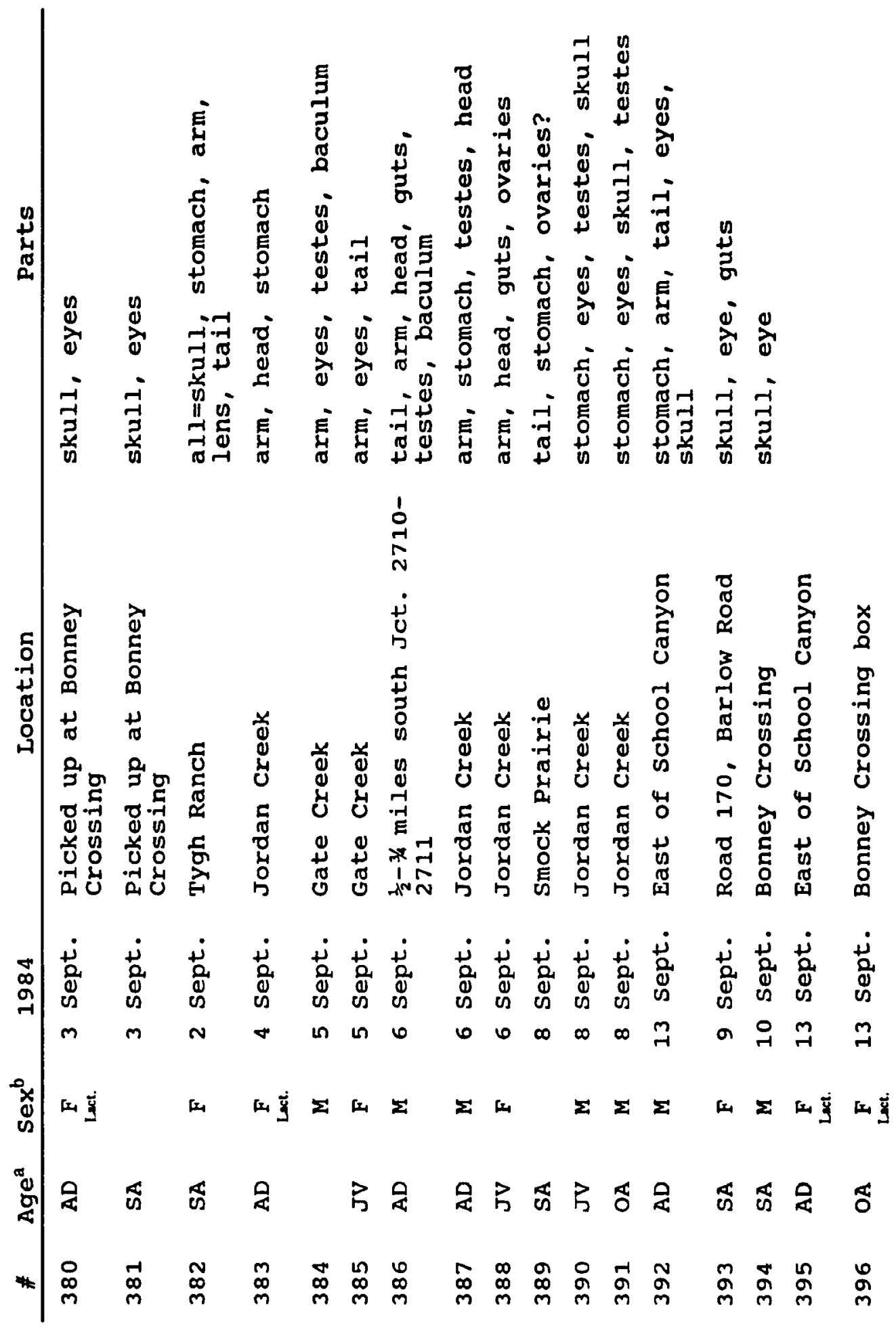




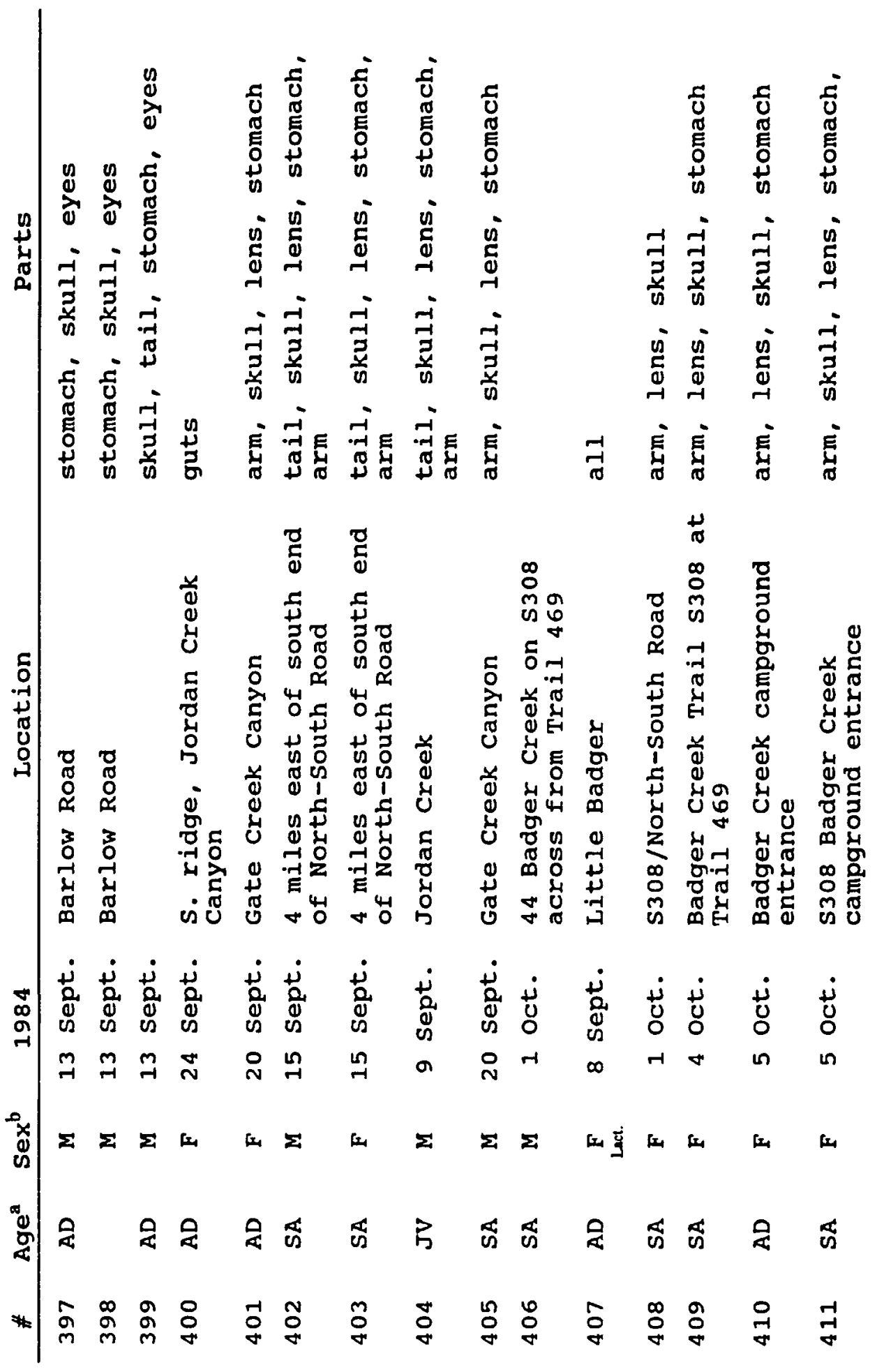




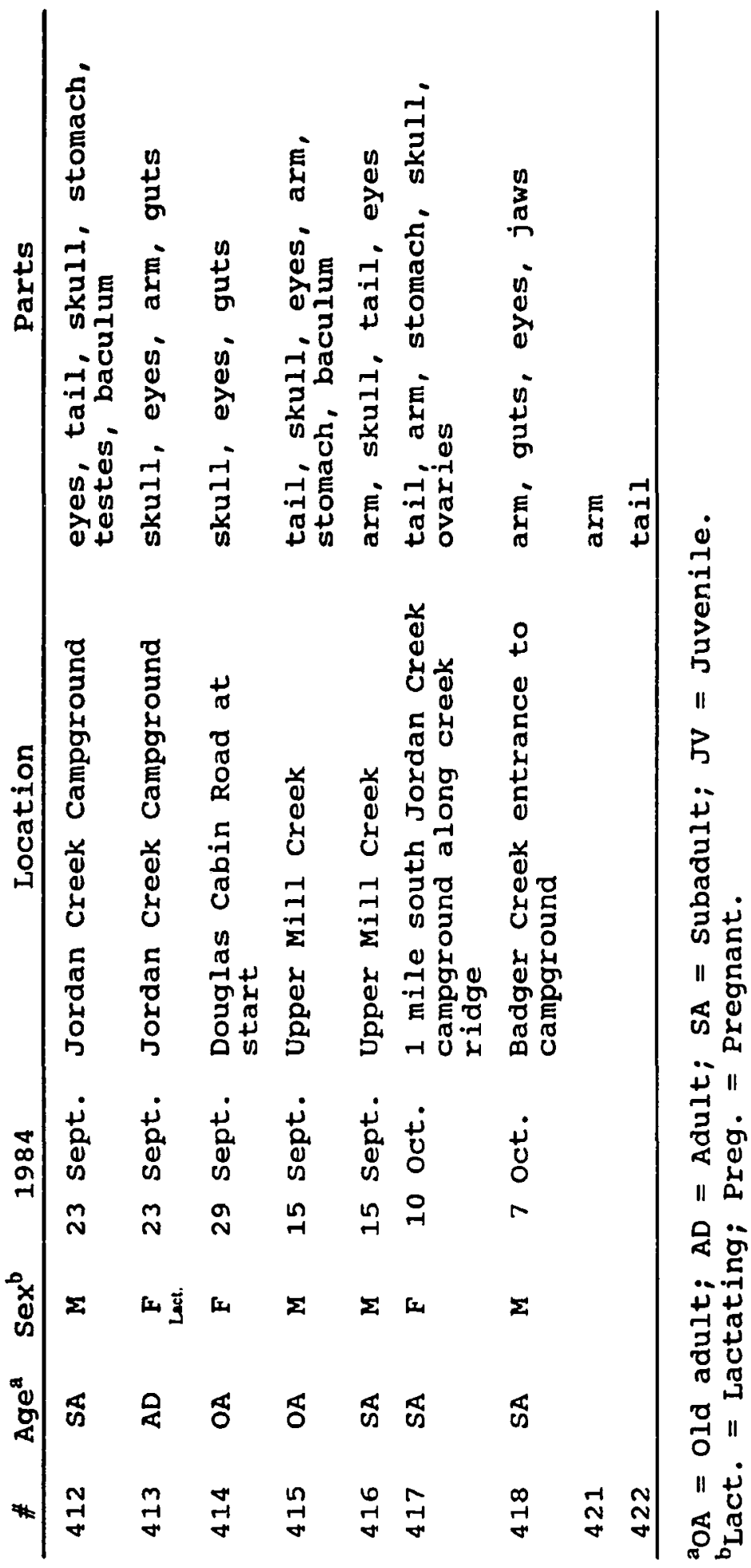




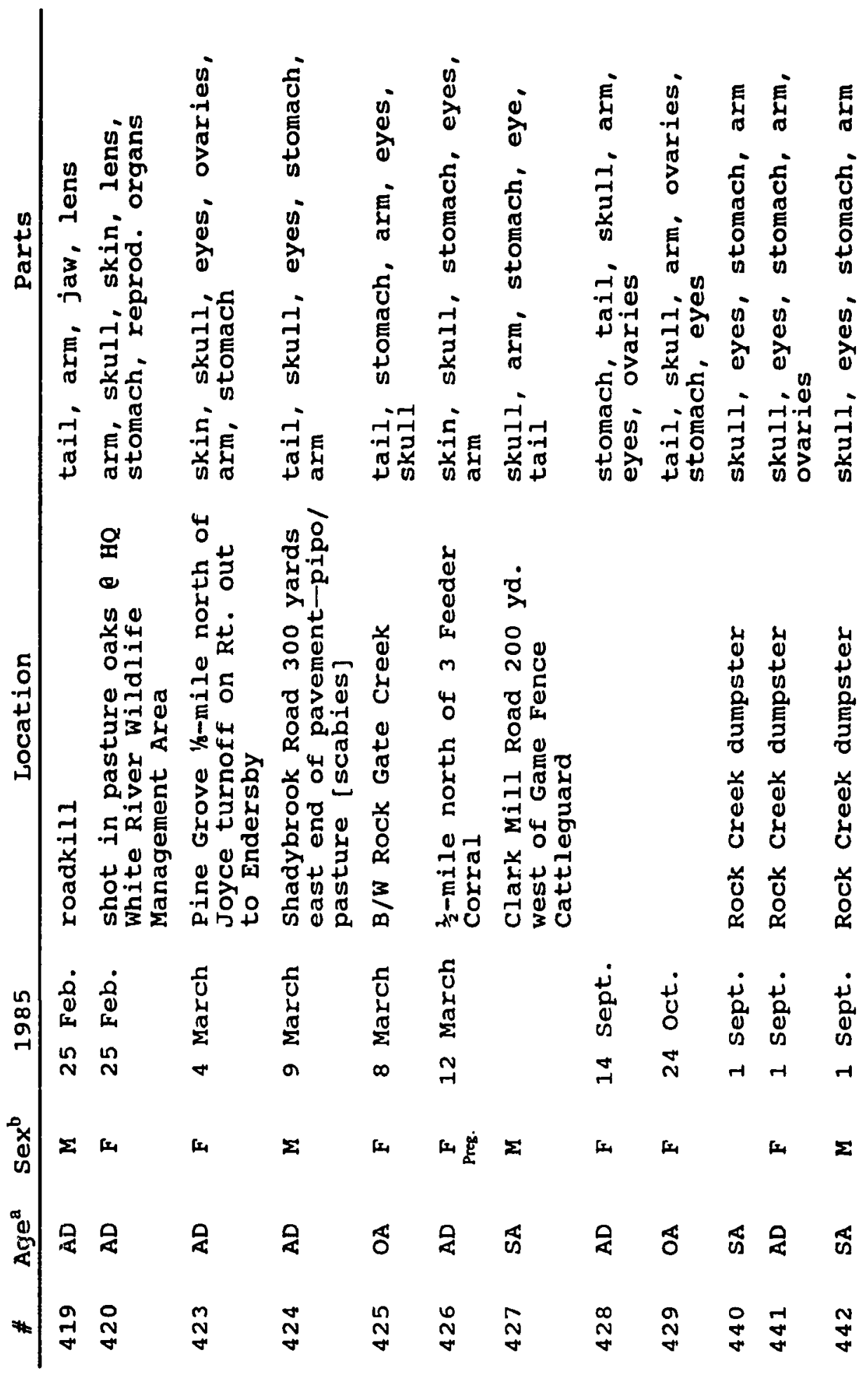




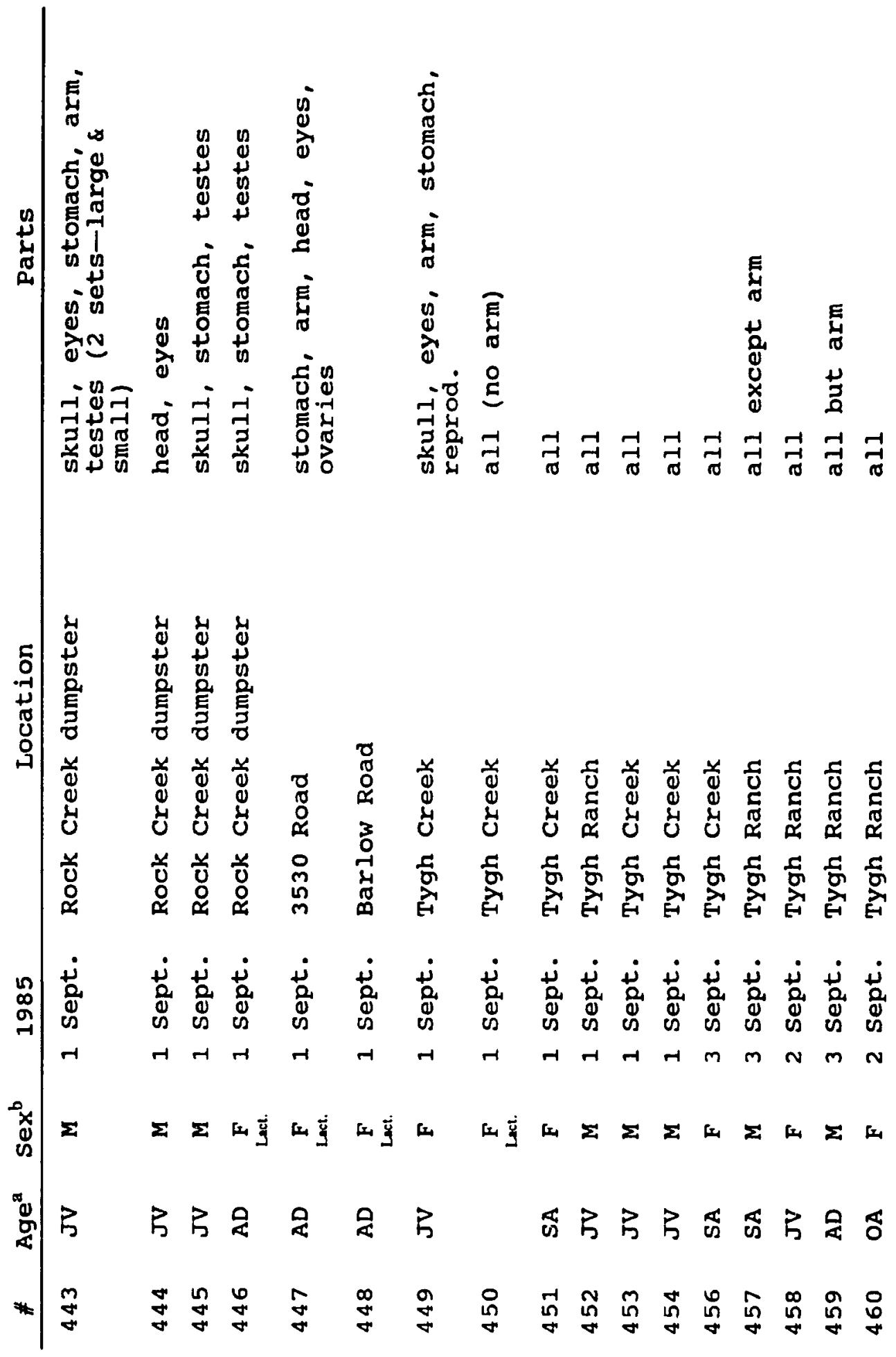




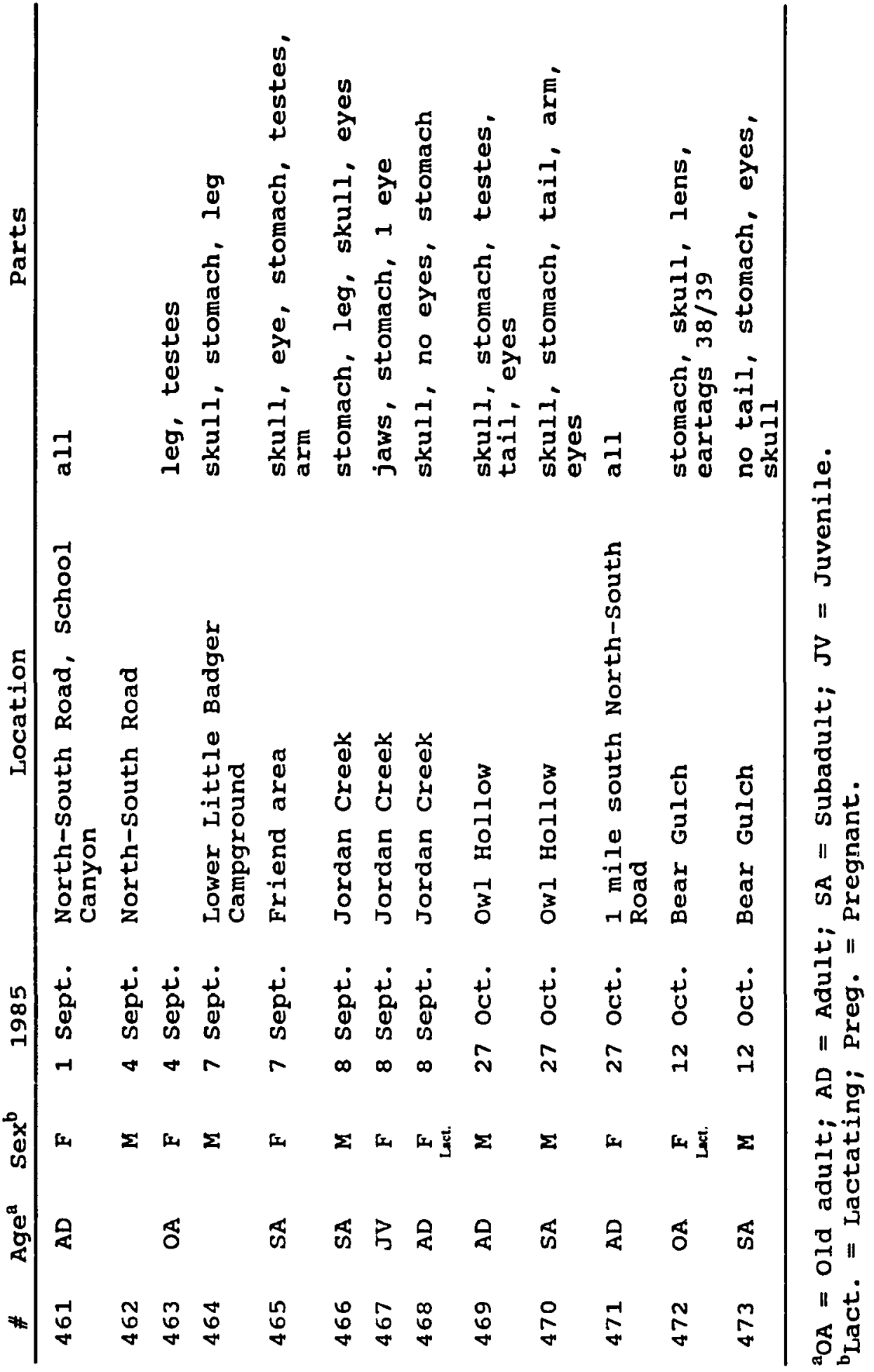




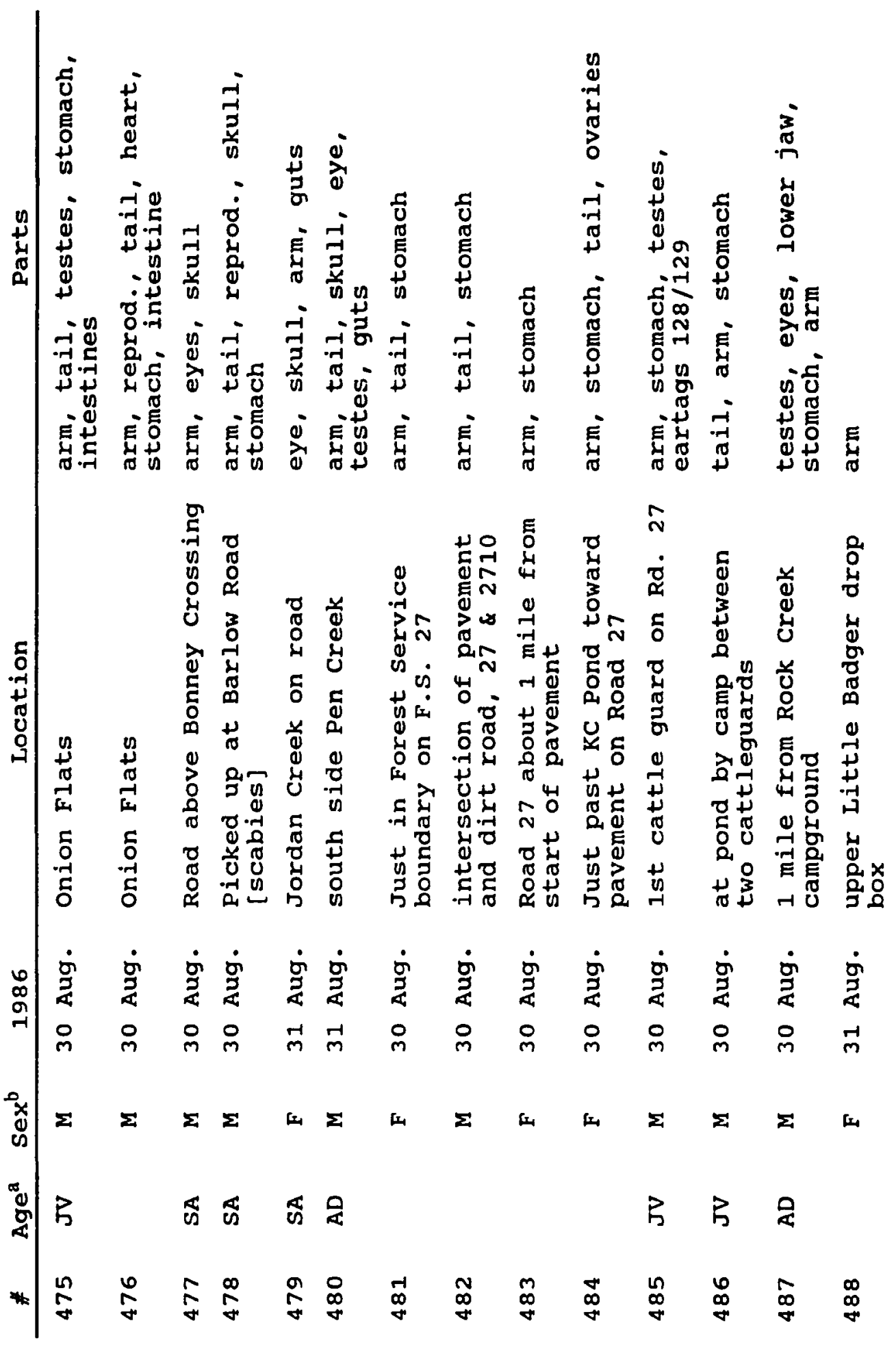




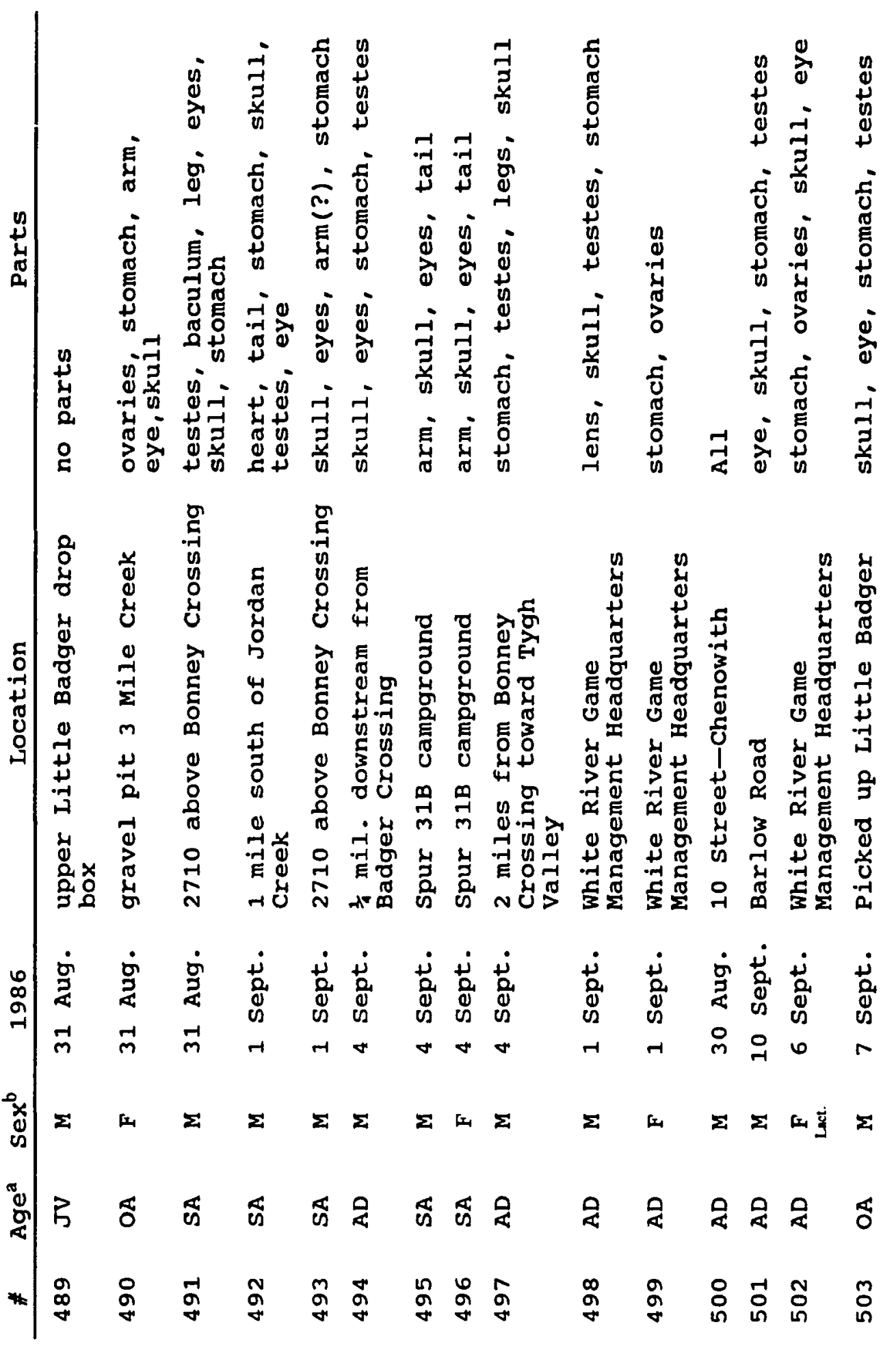




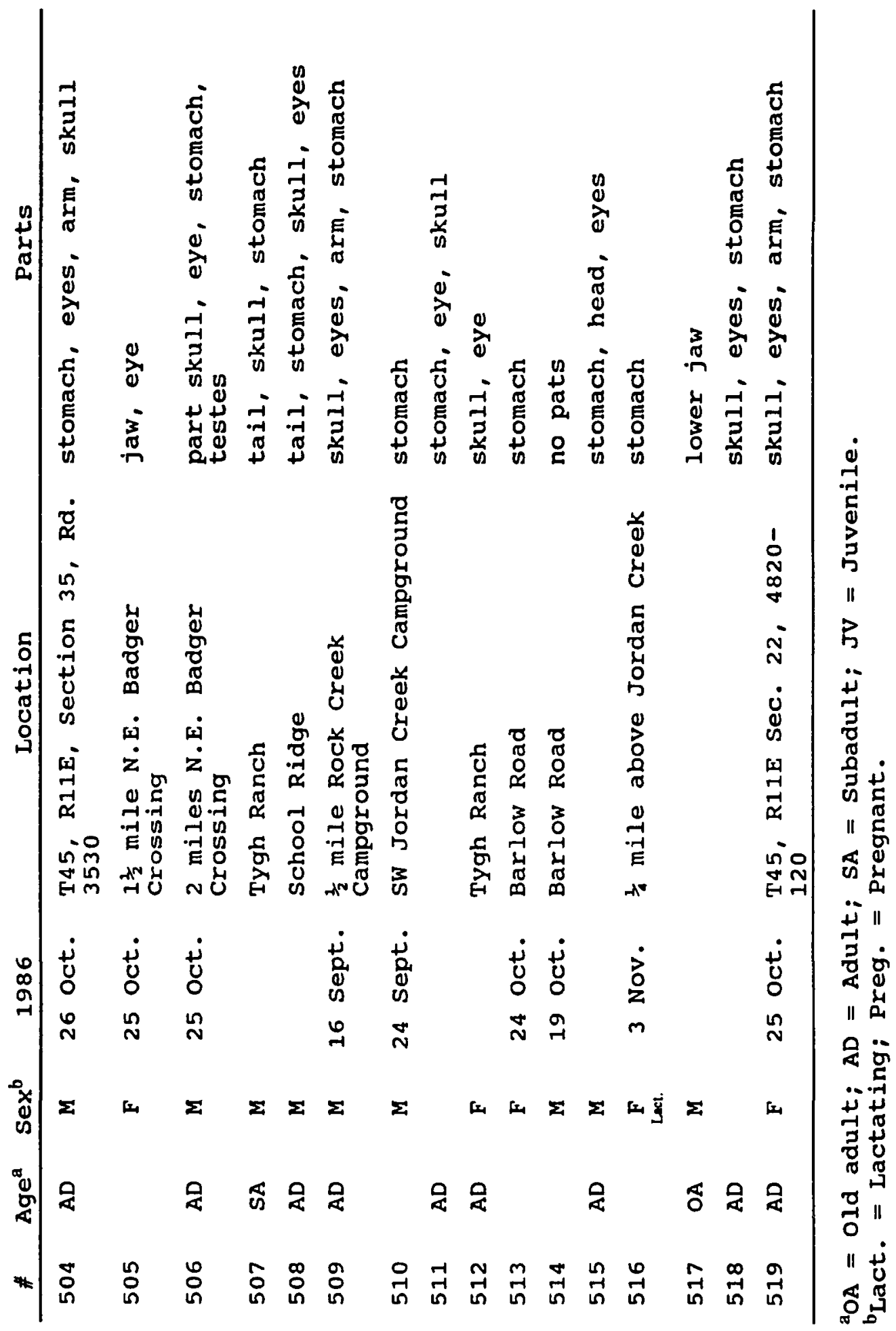




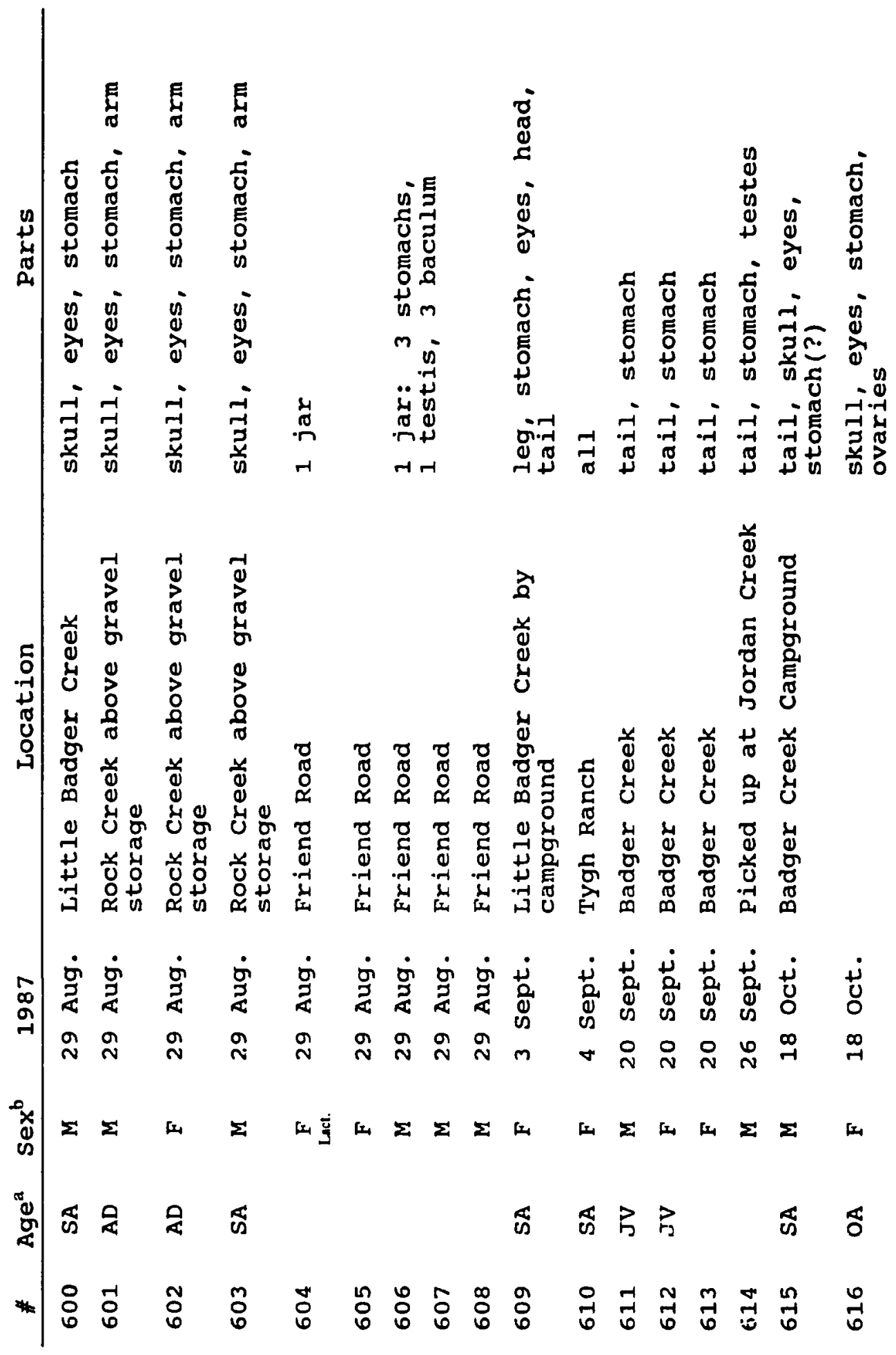




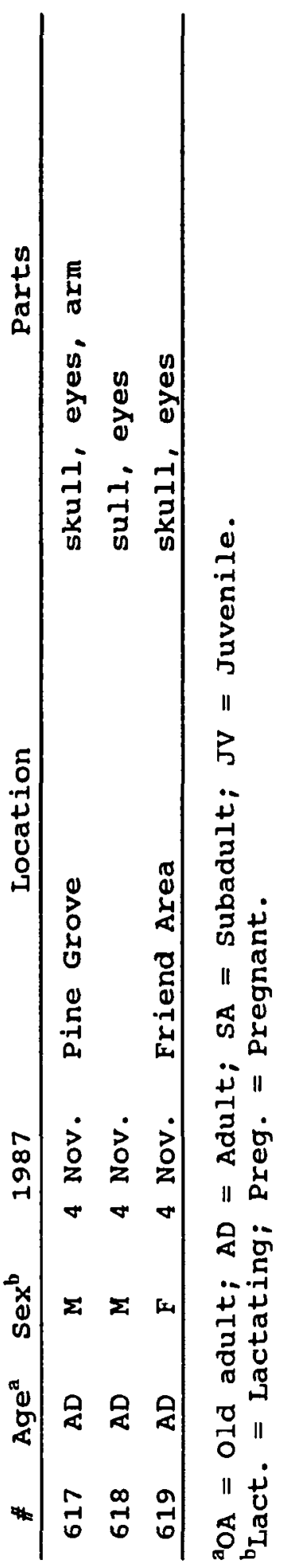


APPENDIX C

NEST TREE SITE MAPS 


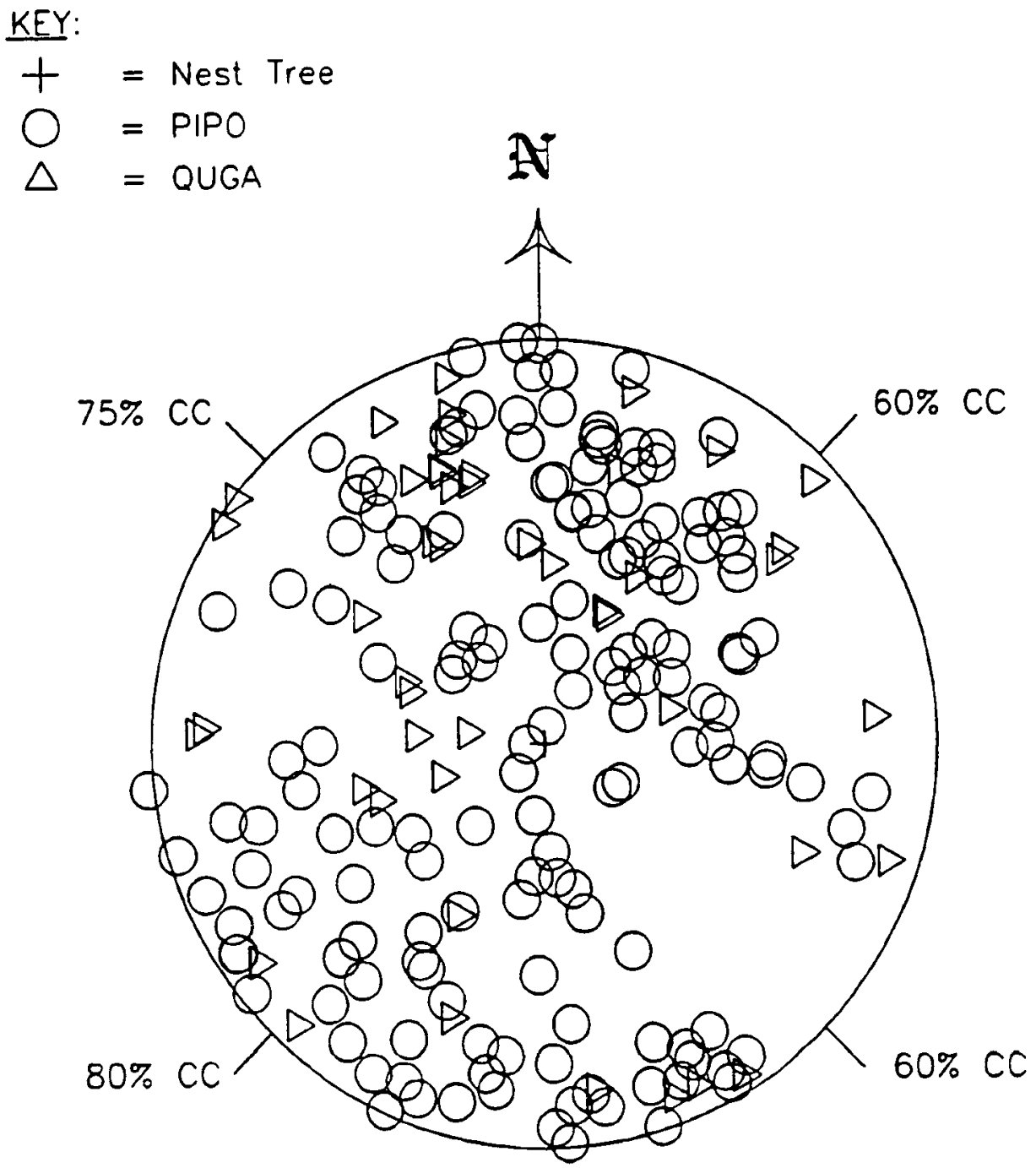

Nest tree site 074 .

Note: $\mathrm{PIPO}=$ ponderosa pine; $\mathrm{QUGA}=$ Oregon white oak; $\mathrm{CC}=\%$ canopy closure. 


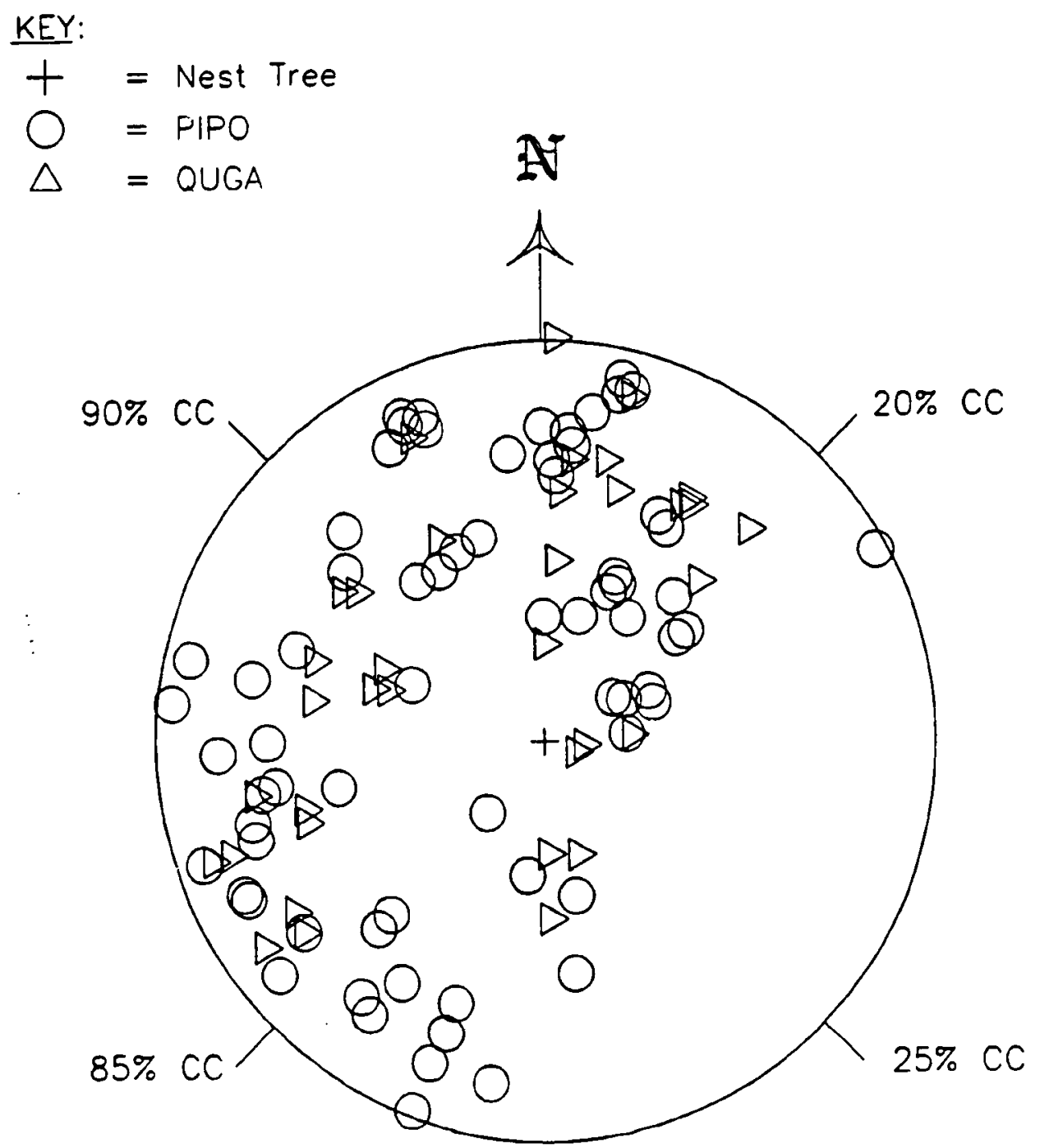

Nest tree site 077.

Note: PIPO = ponderosa pine; QUGA = Oregon white oak;

$\mathrm{CC}=\%$ canopy closure. 


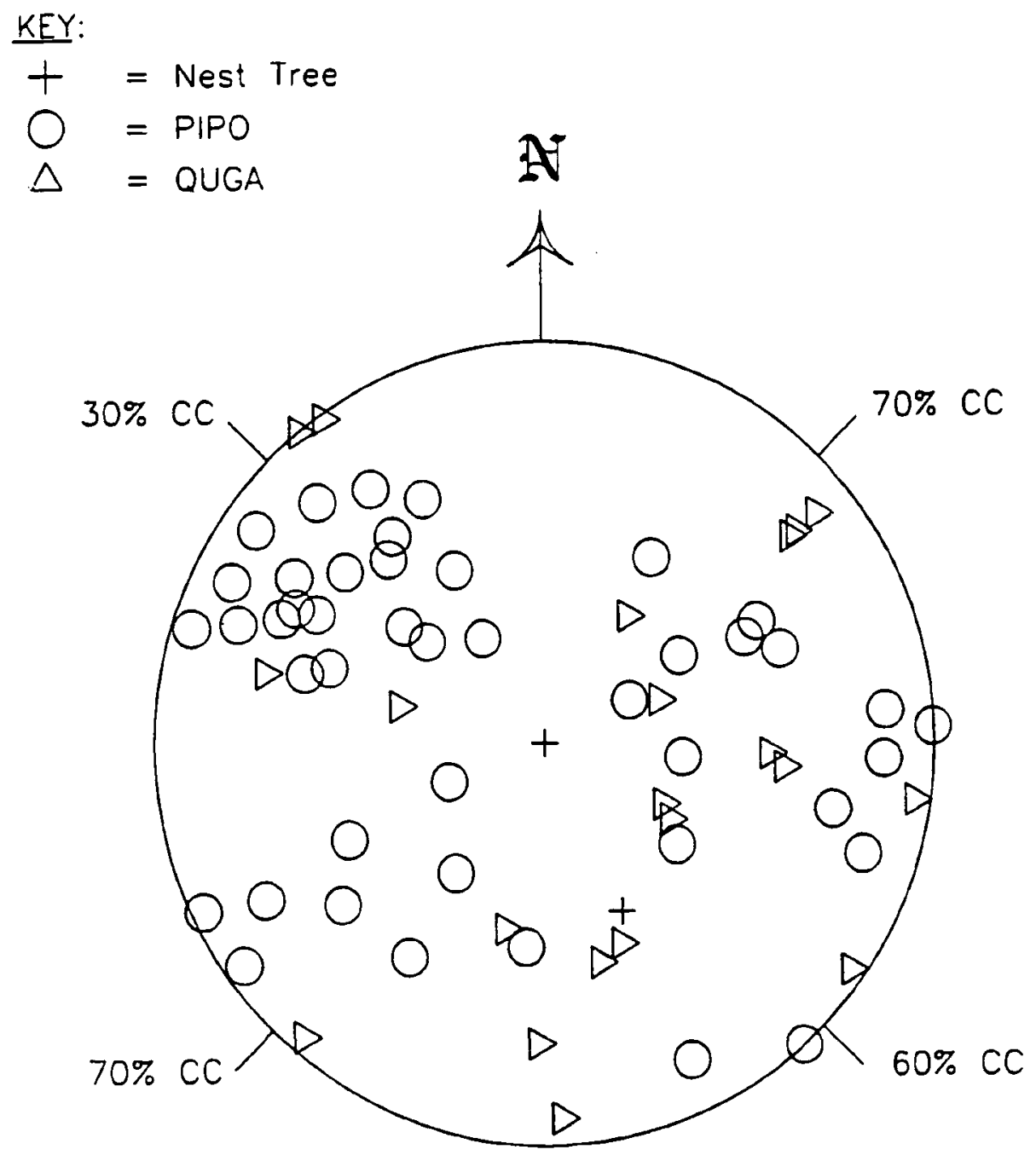

Nest tree site 078 .

Note: $\mathrm{PIPO}=$ ponderosa pine; QUGA = Oregon white oak; $\mathrm{CC}=\%$ canopy closure. 


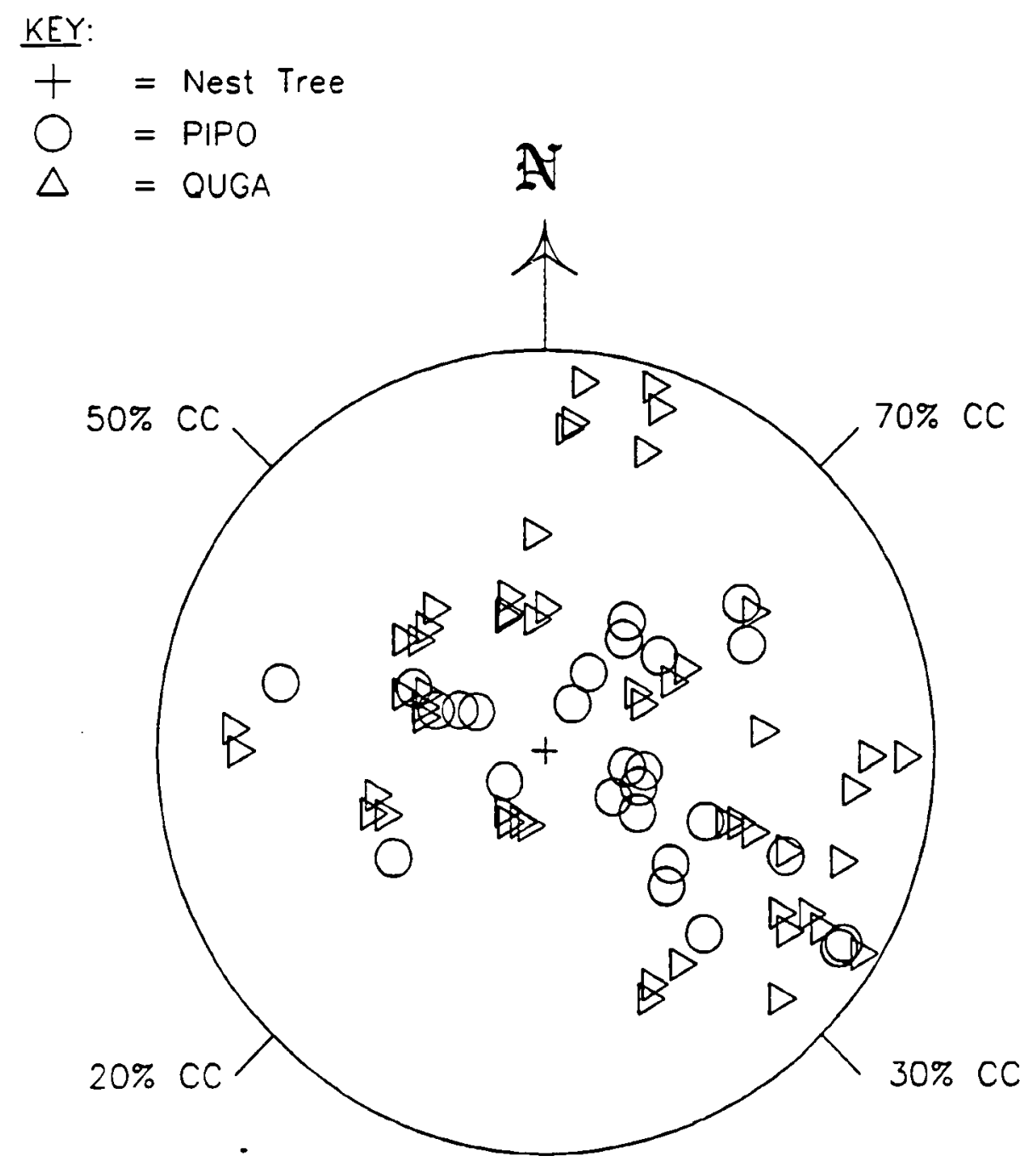

Nest tree site 087 .

Note: PIPO = ponderosa pine; QUGA = Oregon white oak; $\mathrm{CC}=\%$ canopy closure. 
KEY:

$+\quad=$ Nest Tree

$\bigcirc=$ PIPO

$\triangle \quad=$ QUGA

N

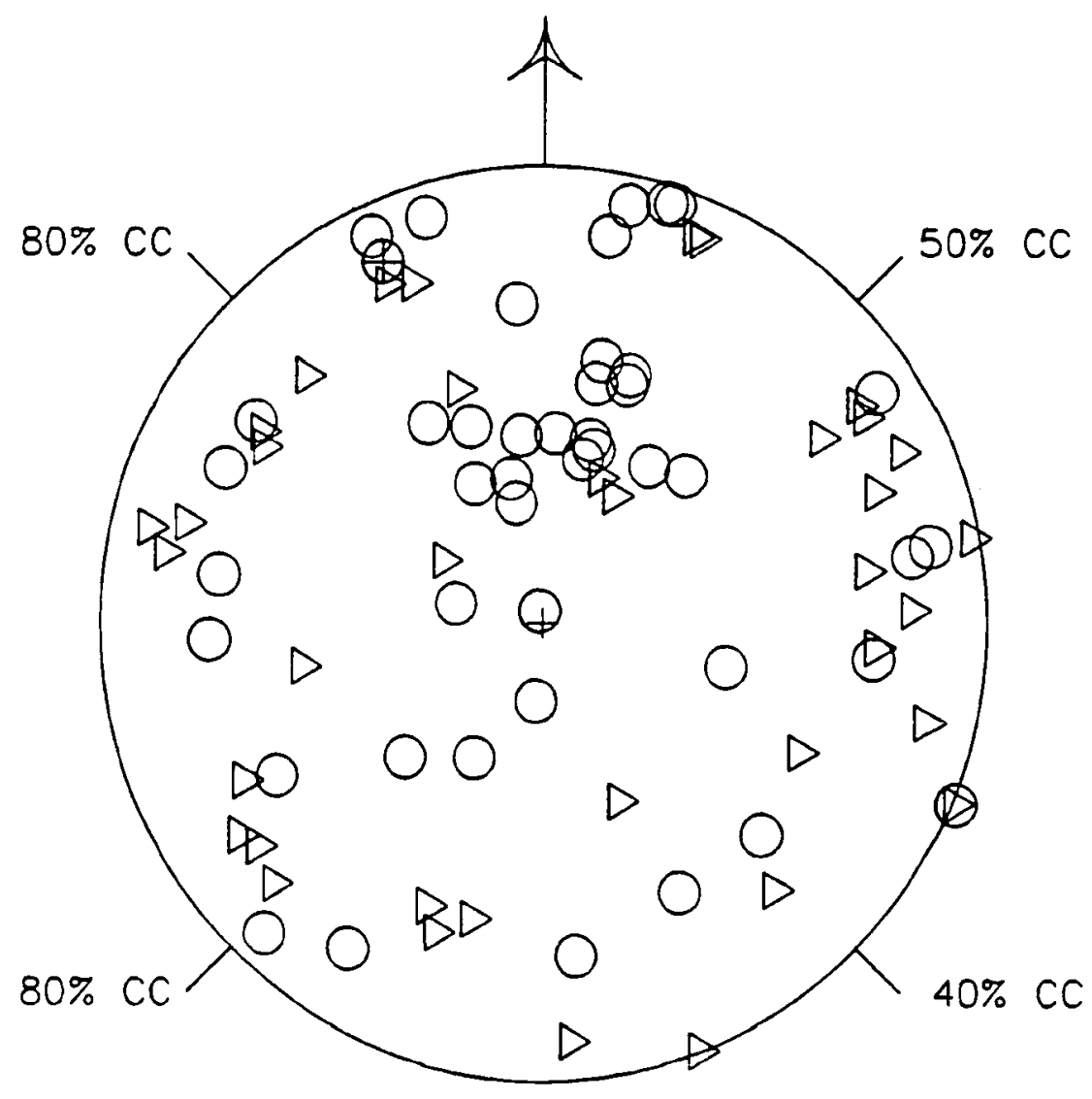

Nest tree site 088 .

Note: $\mathrm{PIPO}=$ ponderosa pine; $\mathrm{QUGA}=$ Oregon white oak;

$\mathrm{CC}=\%$ canopy closure. 


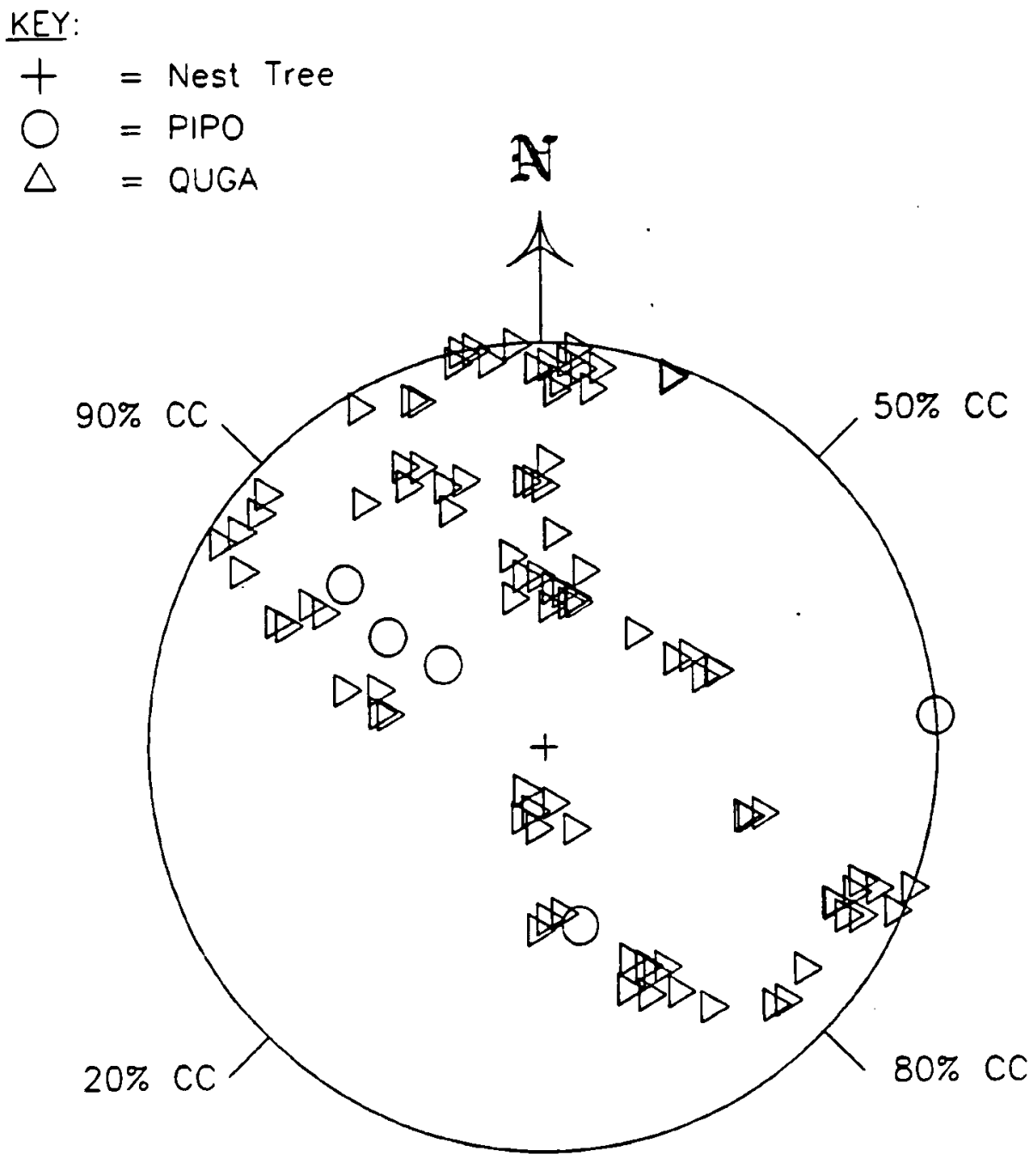

Nest tree site 090 .

Note: PIPO = ponderosa pine; QUGA = Oregon white oak; $\mathrm{CC}=\%$ canopy closure. 


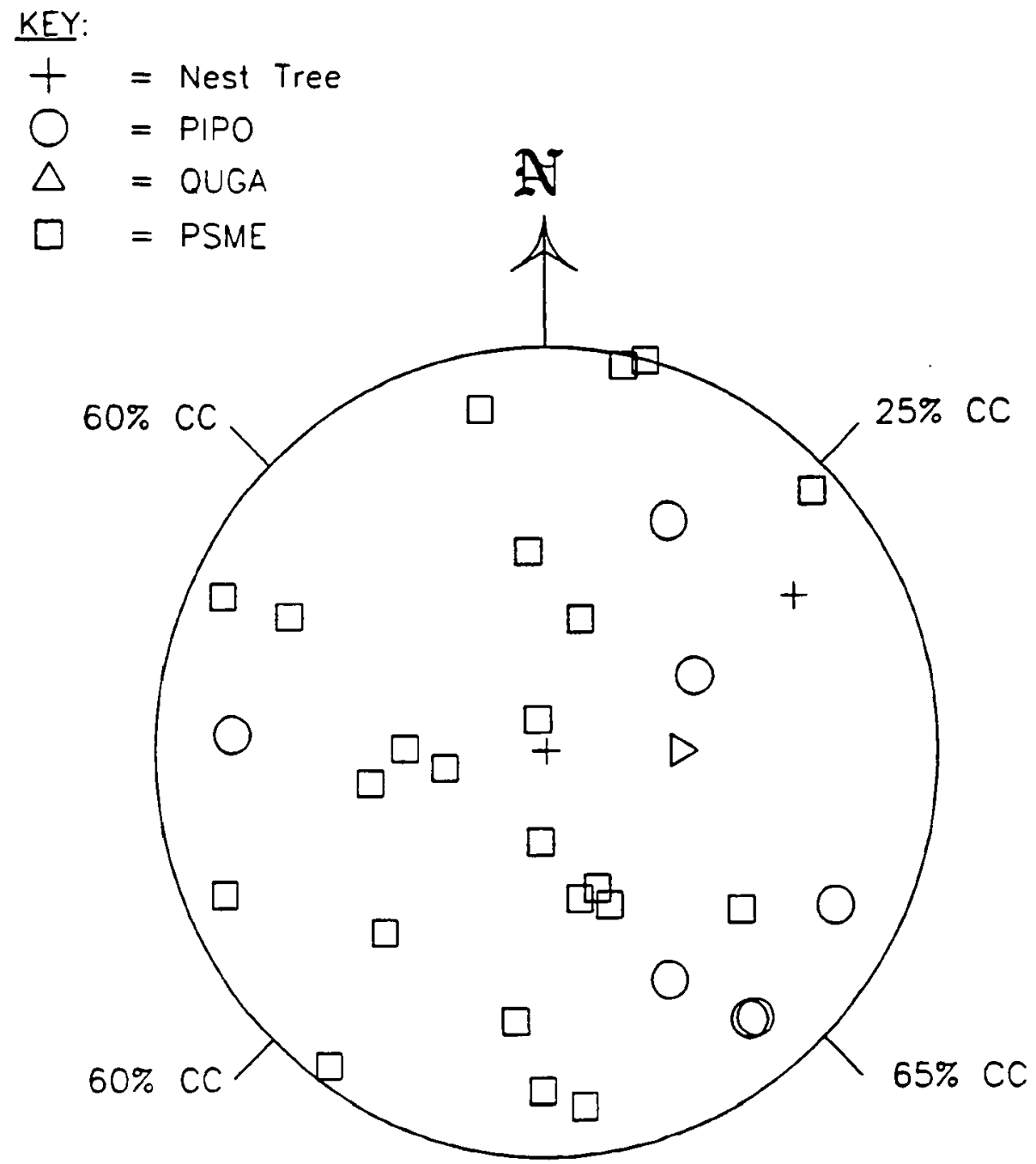

Nest tree site 093.

Note: PIPO = ponderosa pine; QUGA = Oregon white oak;

PSME = Douglas-fir; $\mathrm{CC}=\%$ canopy closure. 


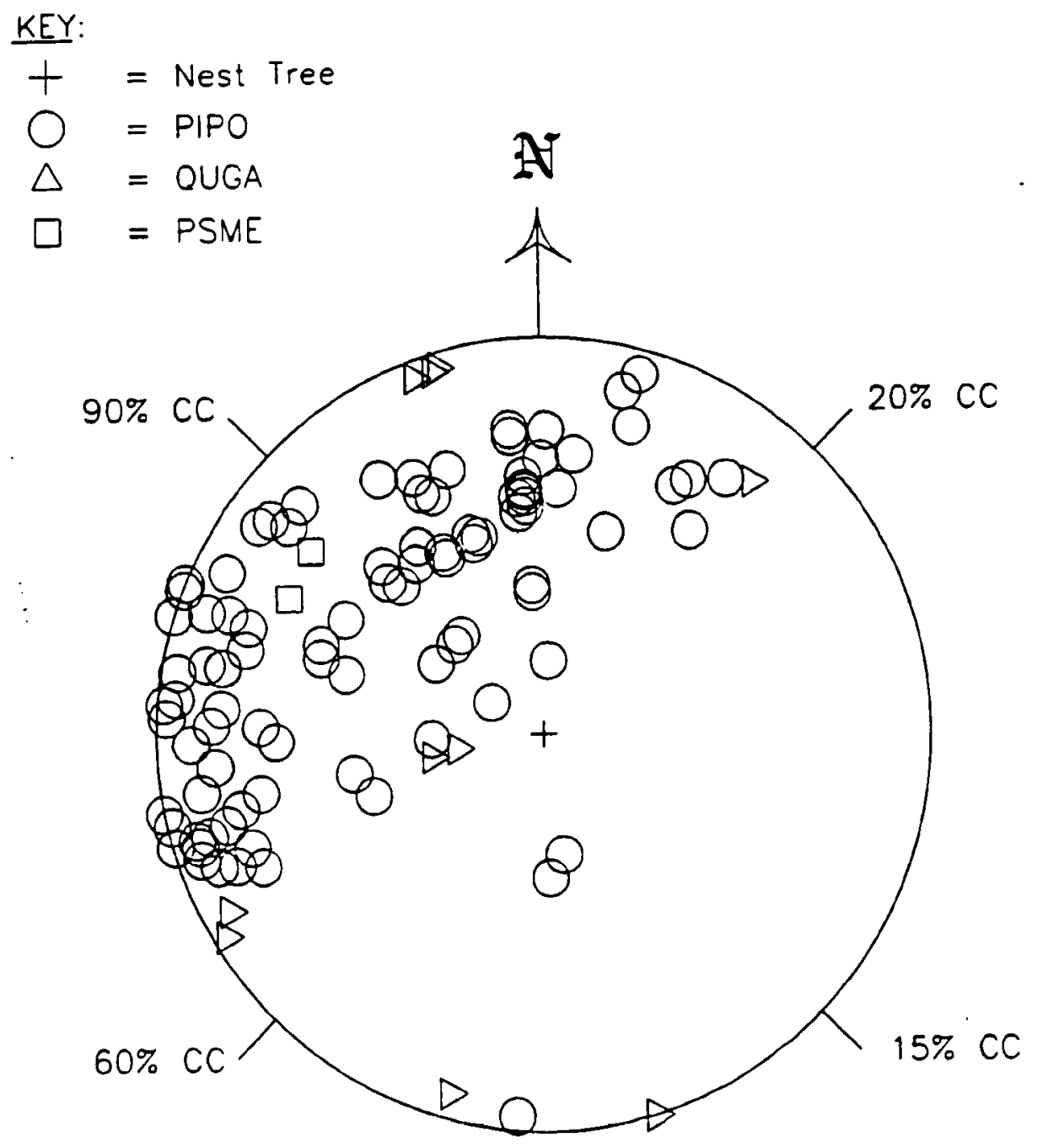

Nest tree site 0941 .

Note: PIPO = ponderosa pine; QUGA = Oregon white oak;

PSME $=$ Douglas-fir; $\mathrm{CC}=\%$ canopy closure. 


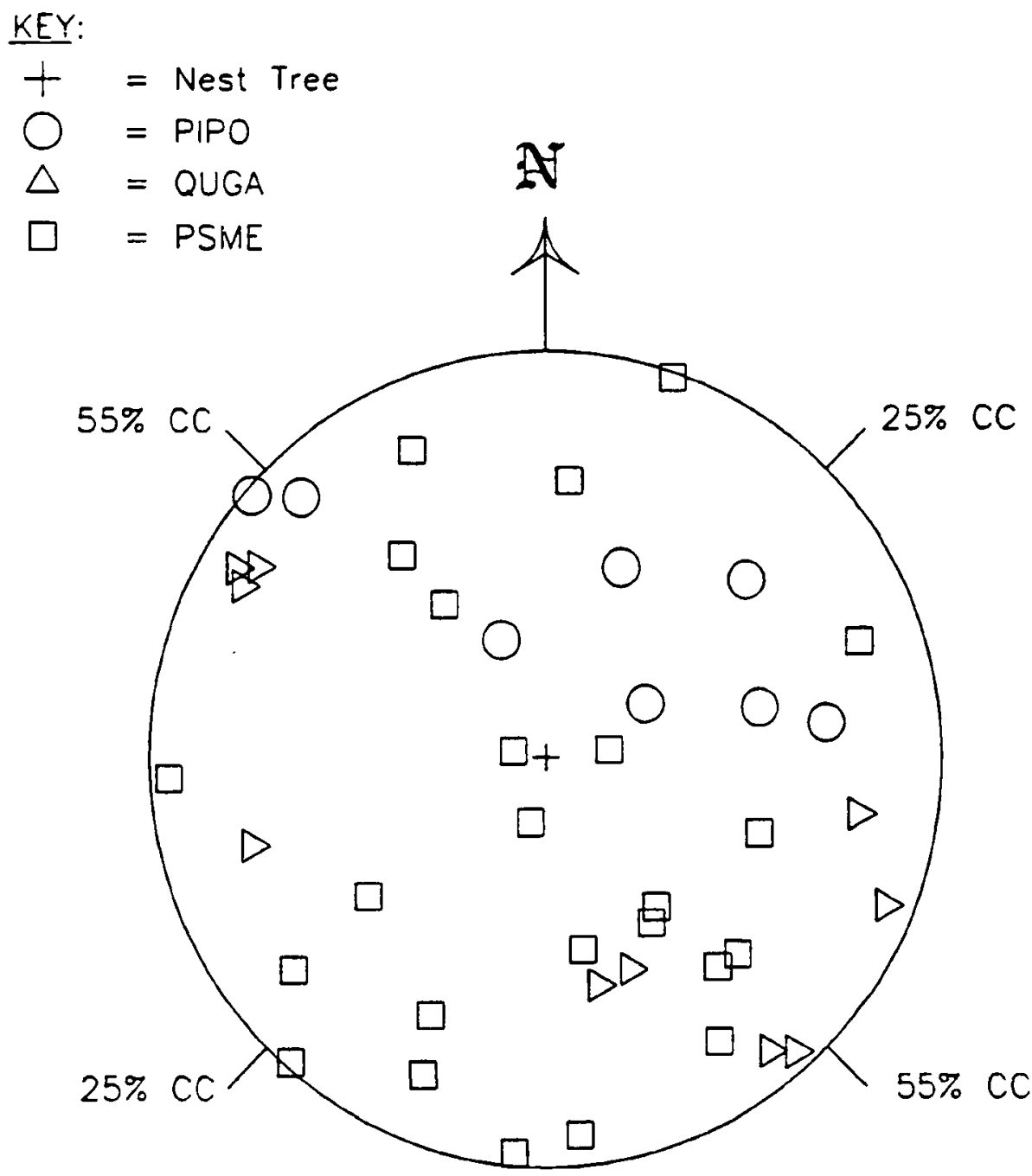

Nest tree site 0942.

Note: PIPO = ponderosa pine; QUGA = Oregon white oak;

PSME = Douglas-fir; $\mathbf{C C}=\%$ canopy closure. 
KEY:

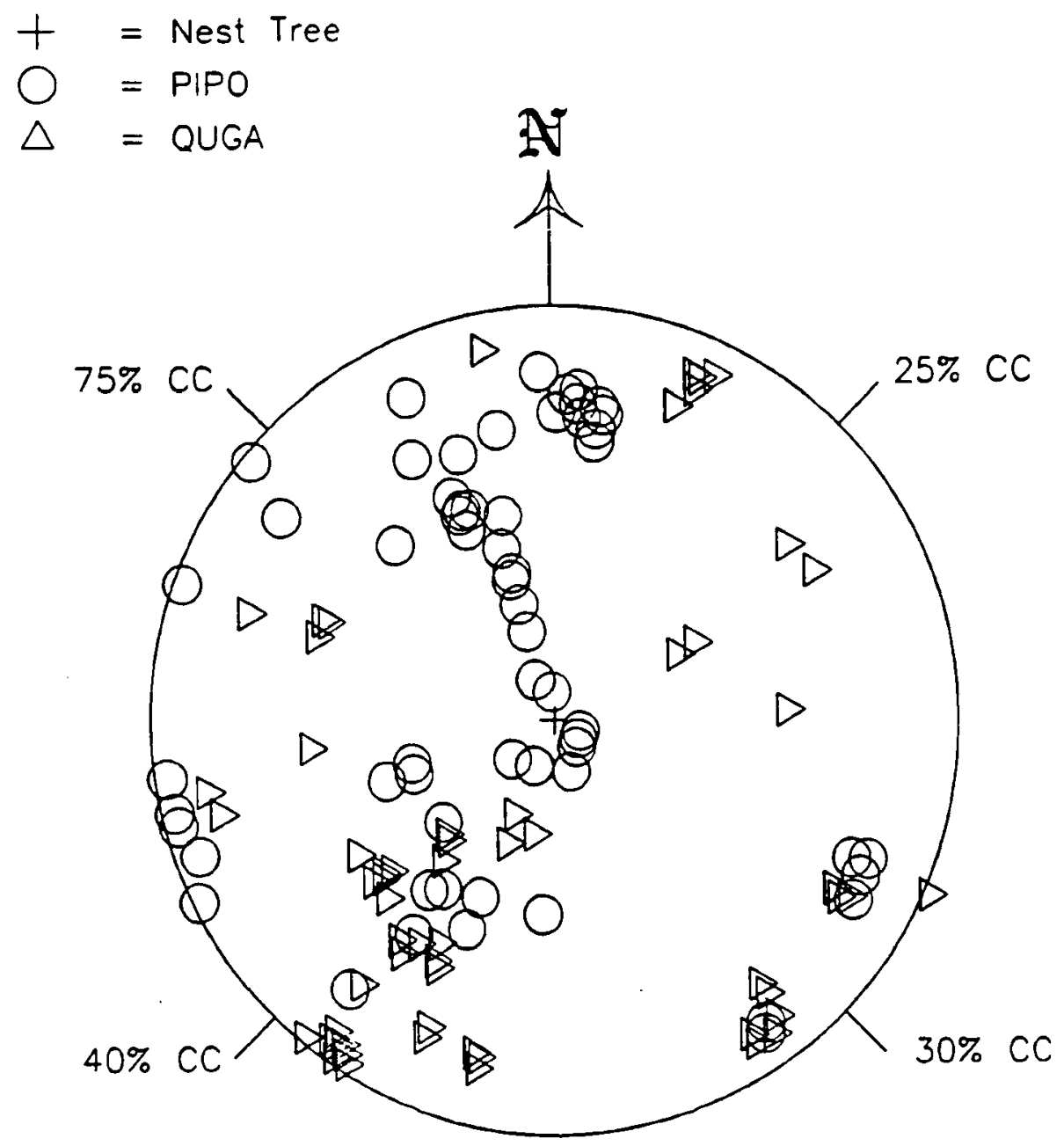

Nest tree site 0951 .

Note: $\mathrm{PIPO}=$ ponderosa pine; $\mathrm{QUGA}=$ Oregon white oak; $\mathrm{CC}=\%$ canopy closure. 


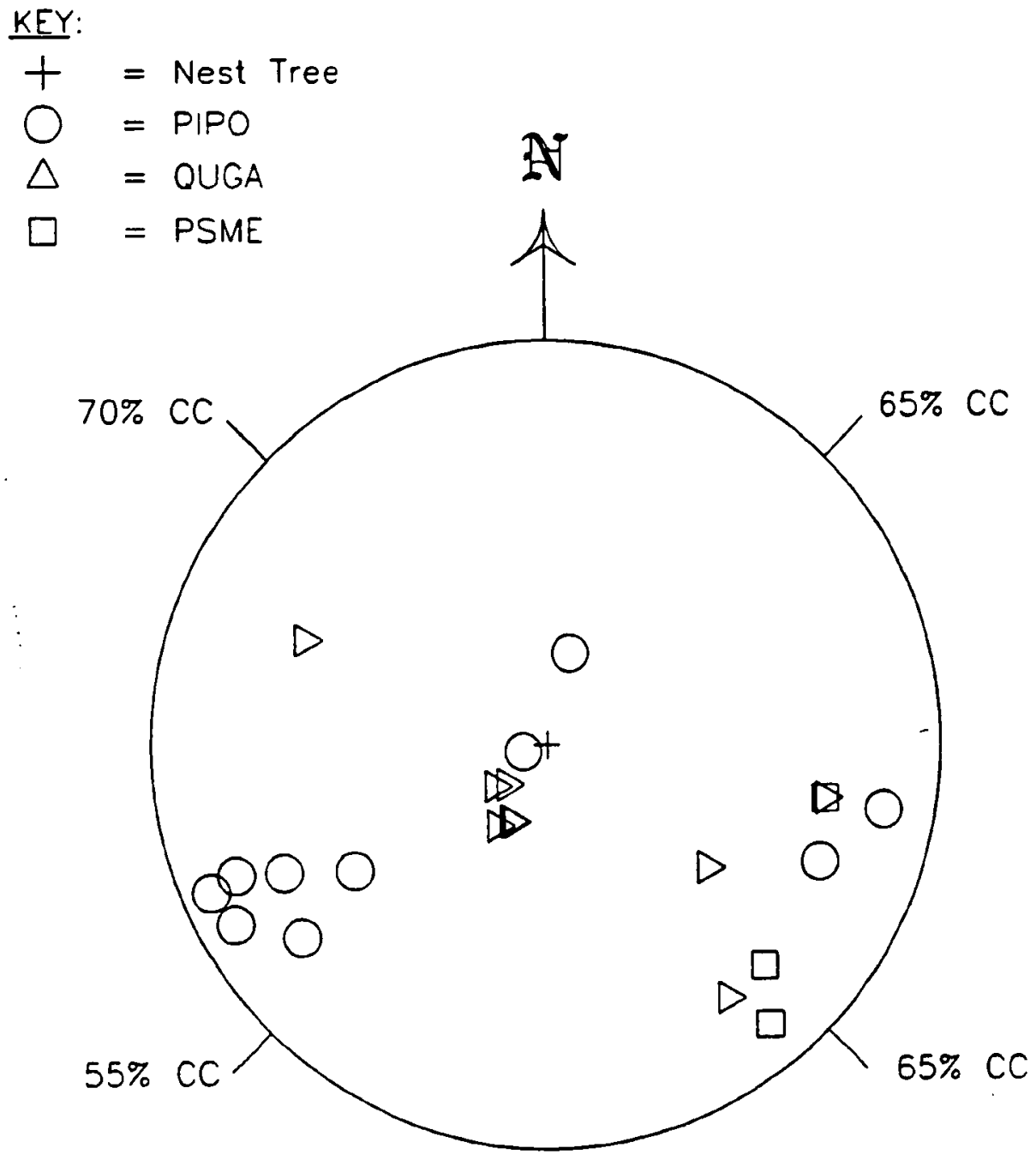

Nest tree site 0952.

Note: PIPO = ponderosa pine; QUGA = Oregon white oak;

PSME = Douglas-fir; $\mathrm{CC}=\%$ canopy closure. 


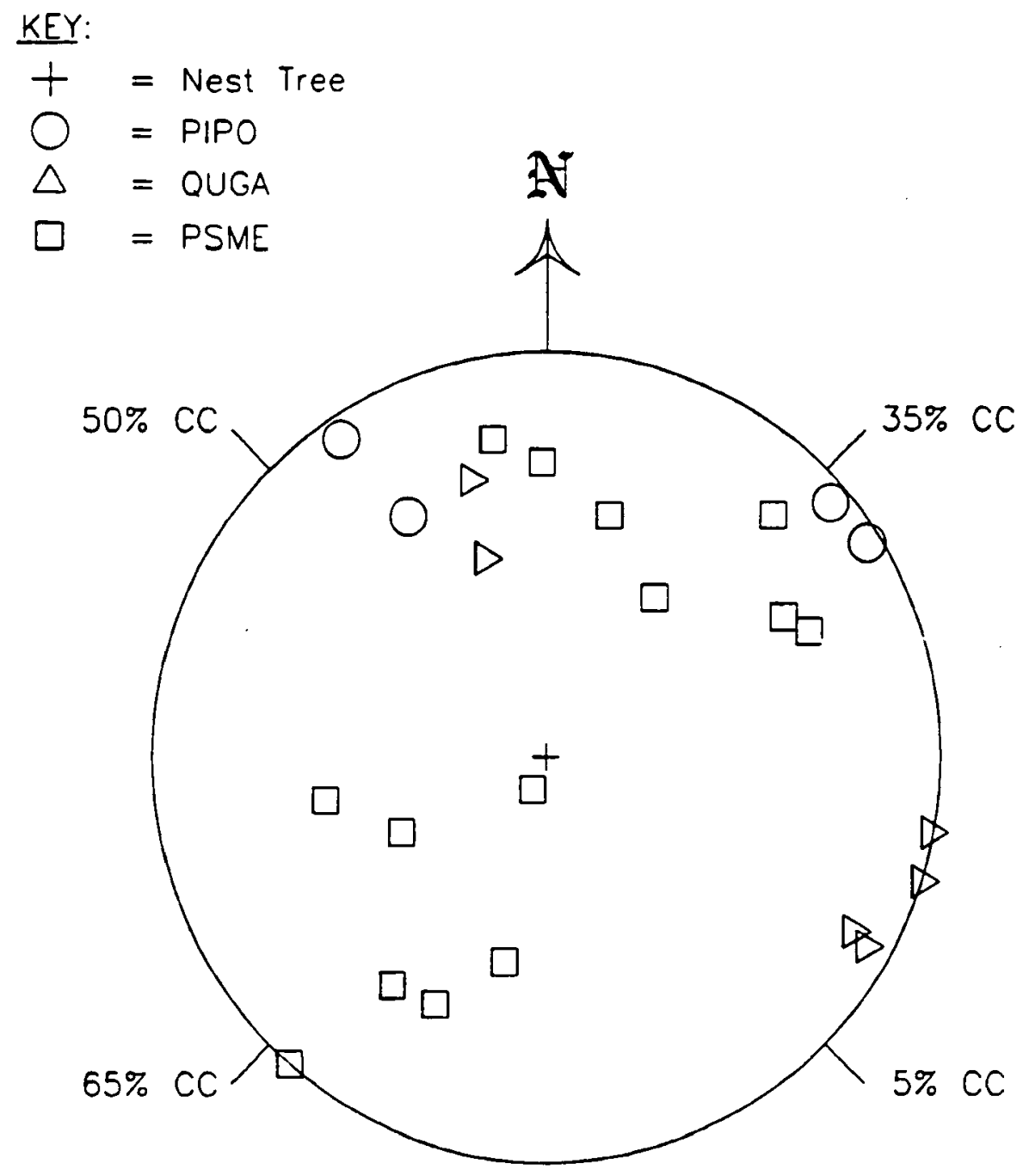

Nest tree site 096.

Note: $\mathrm{PIPO}=$ ponderosa pine; $\mathrm{QUGA}=$ Oregon white oak;

PSME = Douglas-fir; $\mathrm{CC}=\%$ canopy closure. 


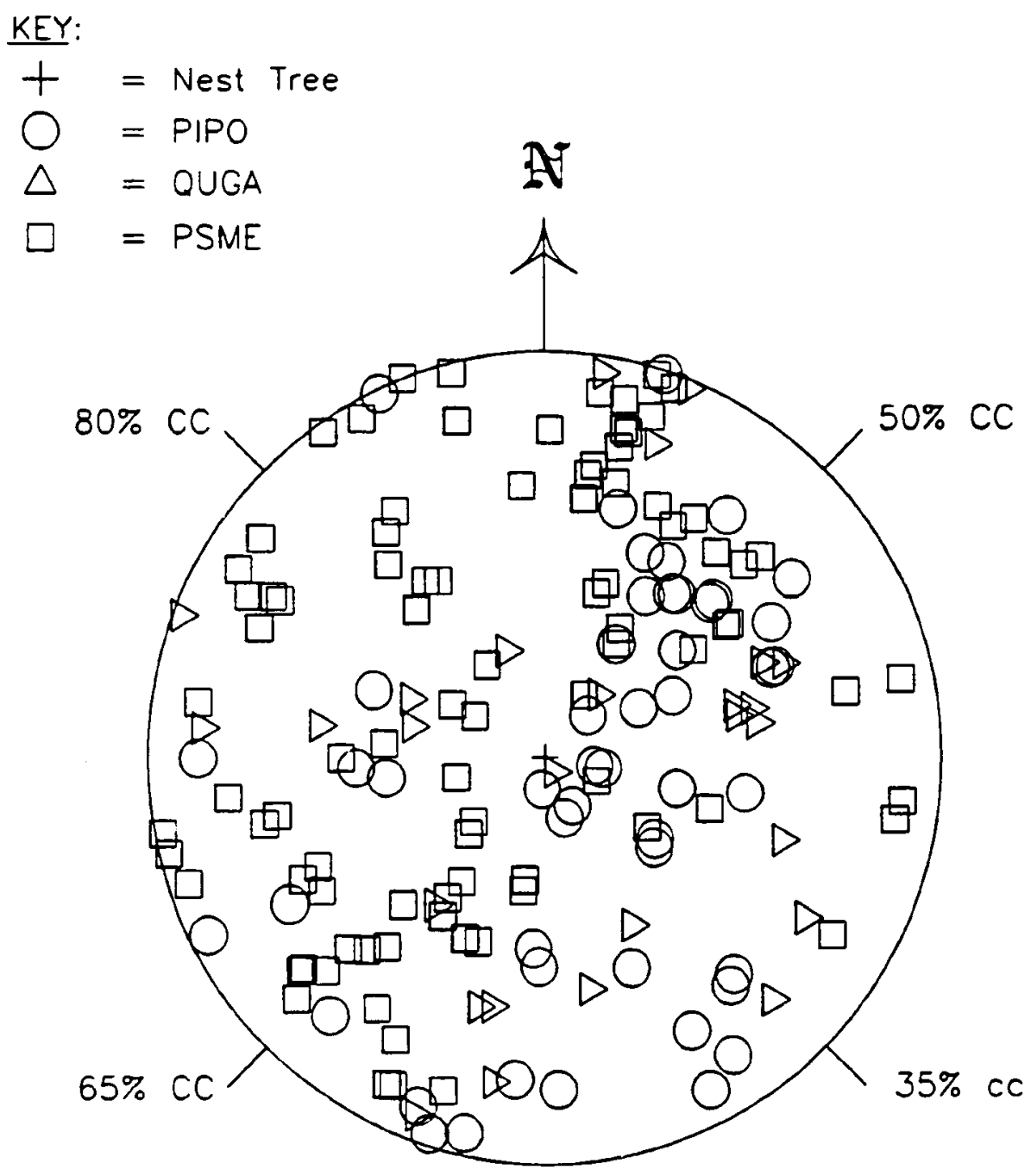

Nest tree site 097.

Note: PIPO = ponderosa pine; QUGA = Oregon white oak;

PSME = Douglas-fir; $\mathrm{CC}=\%$ canopy closure. 


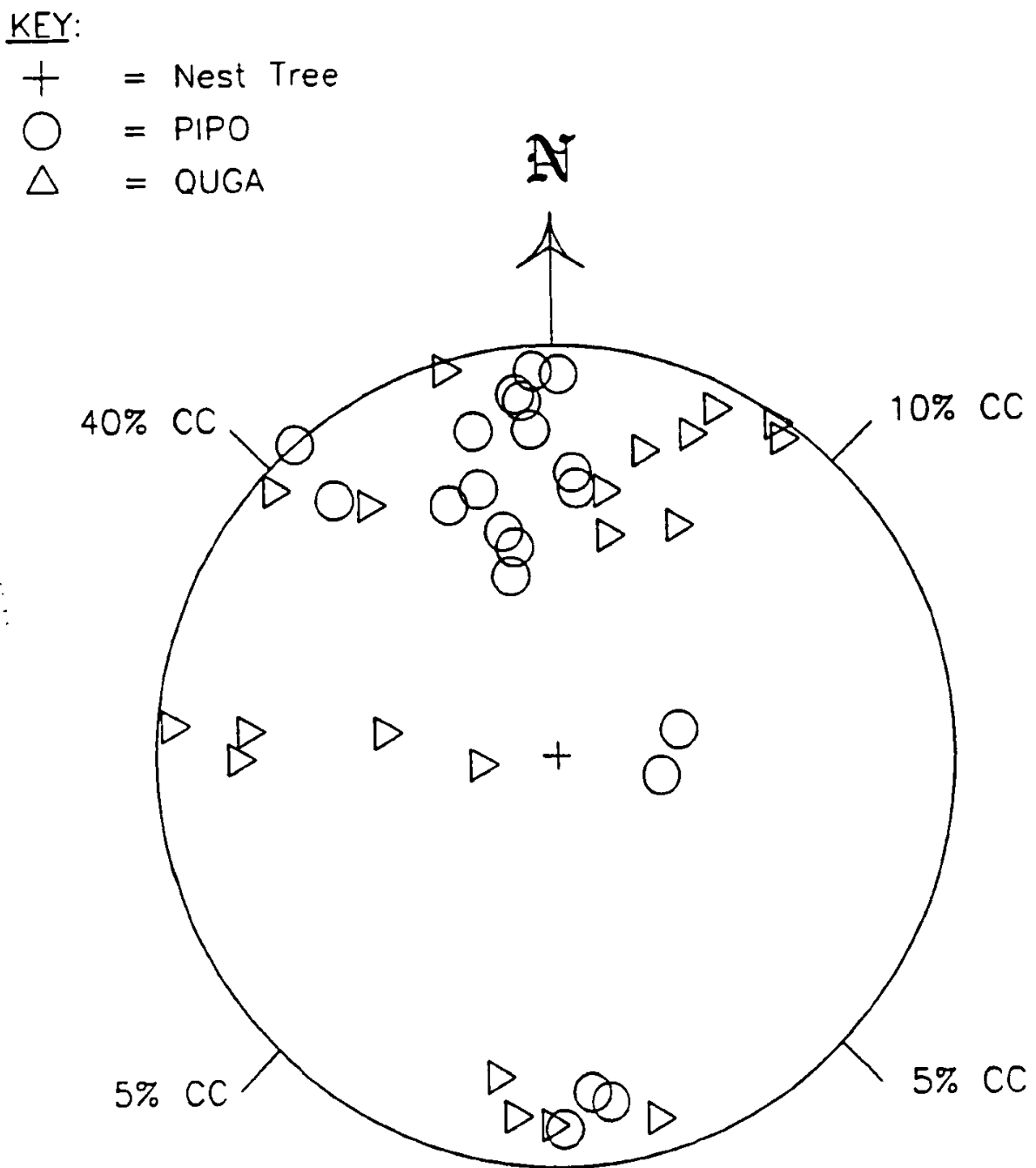

Nest tree site 098.

Note: PIPO = ponderosa pine; QUGA = Oregon white oak; $\mathrm{CC}=\%$ canopy closure. 


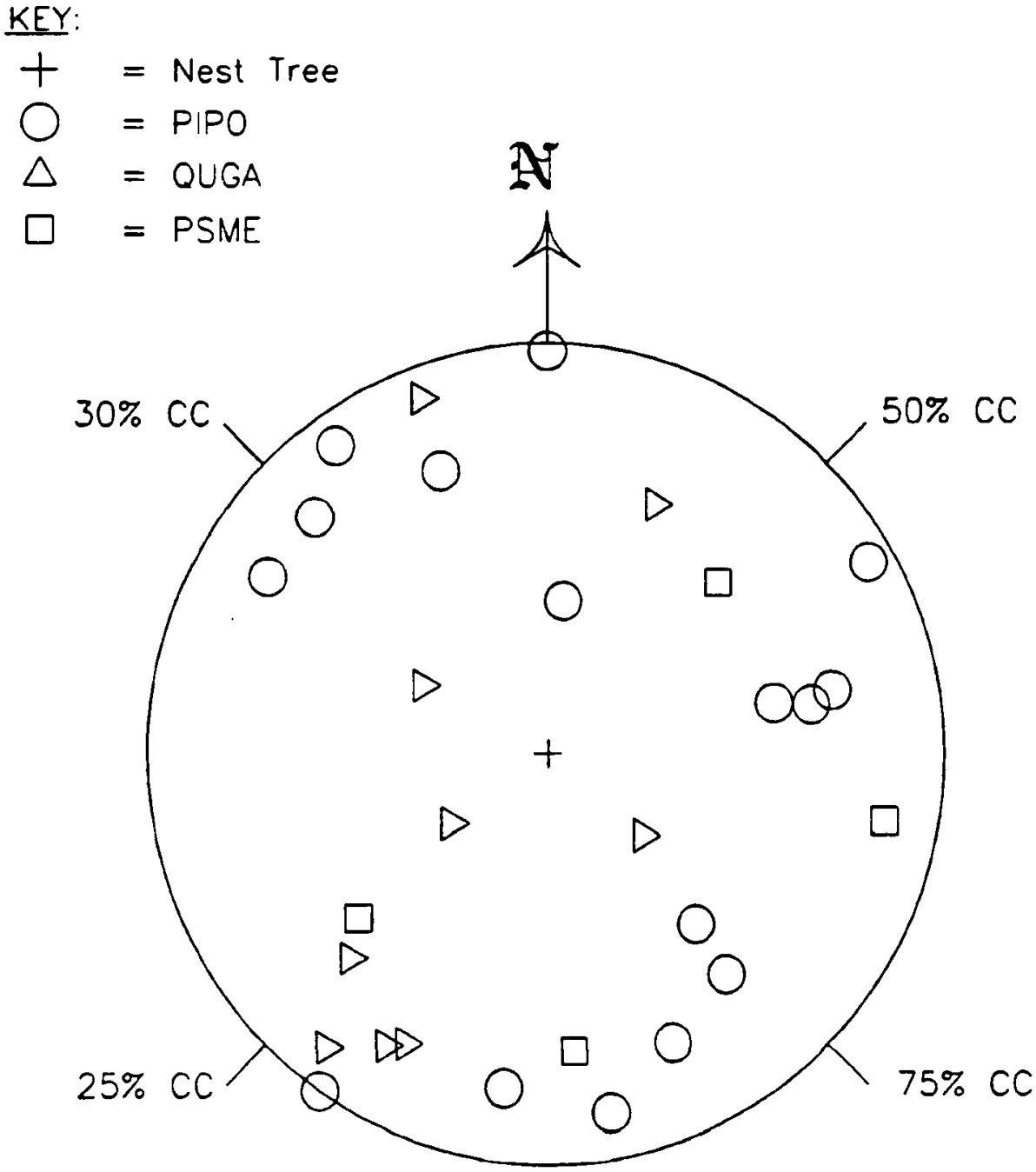

Nest tree site 099 .

Note: PIPO = ponderosa pine; QUGA = Oregon white oak;

PSME $=$ Douglas-fir; $\mathrm{CC}=\%$ canopy closure. 


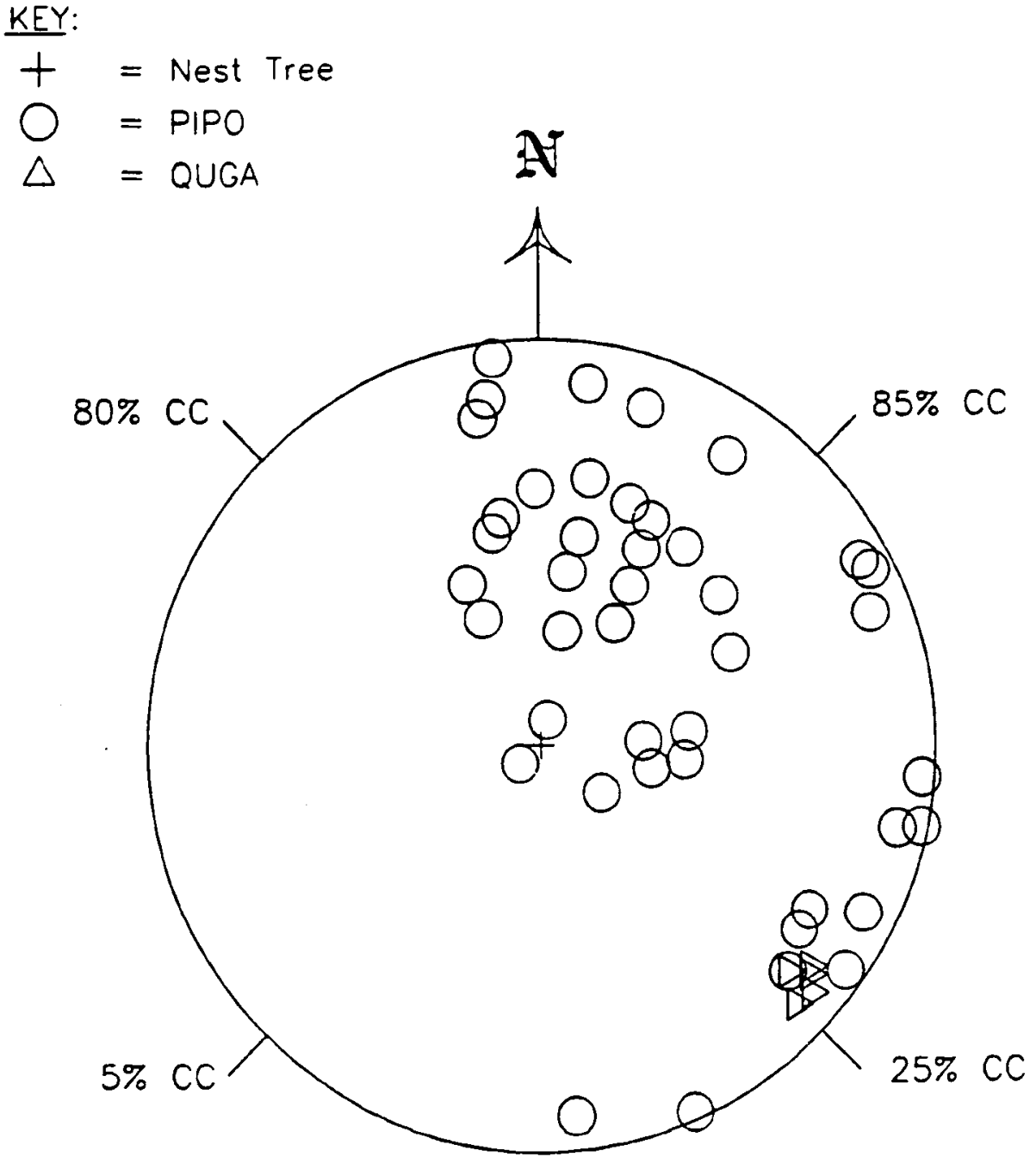

Nest tree site 100.

Note: PIPO = ponderosa pine; QUGA = Oregon white oak; $\mathrm{CC}=\%$ canopy closure. 


$$
\begin{aligned}
\frac{\text { KEY: }}{+} & =\text { Nest Tree } \\
O & =\text { PIPO }
\end{aligned}
$$

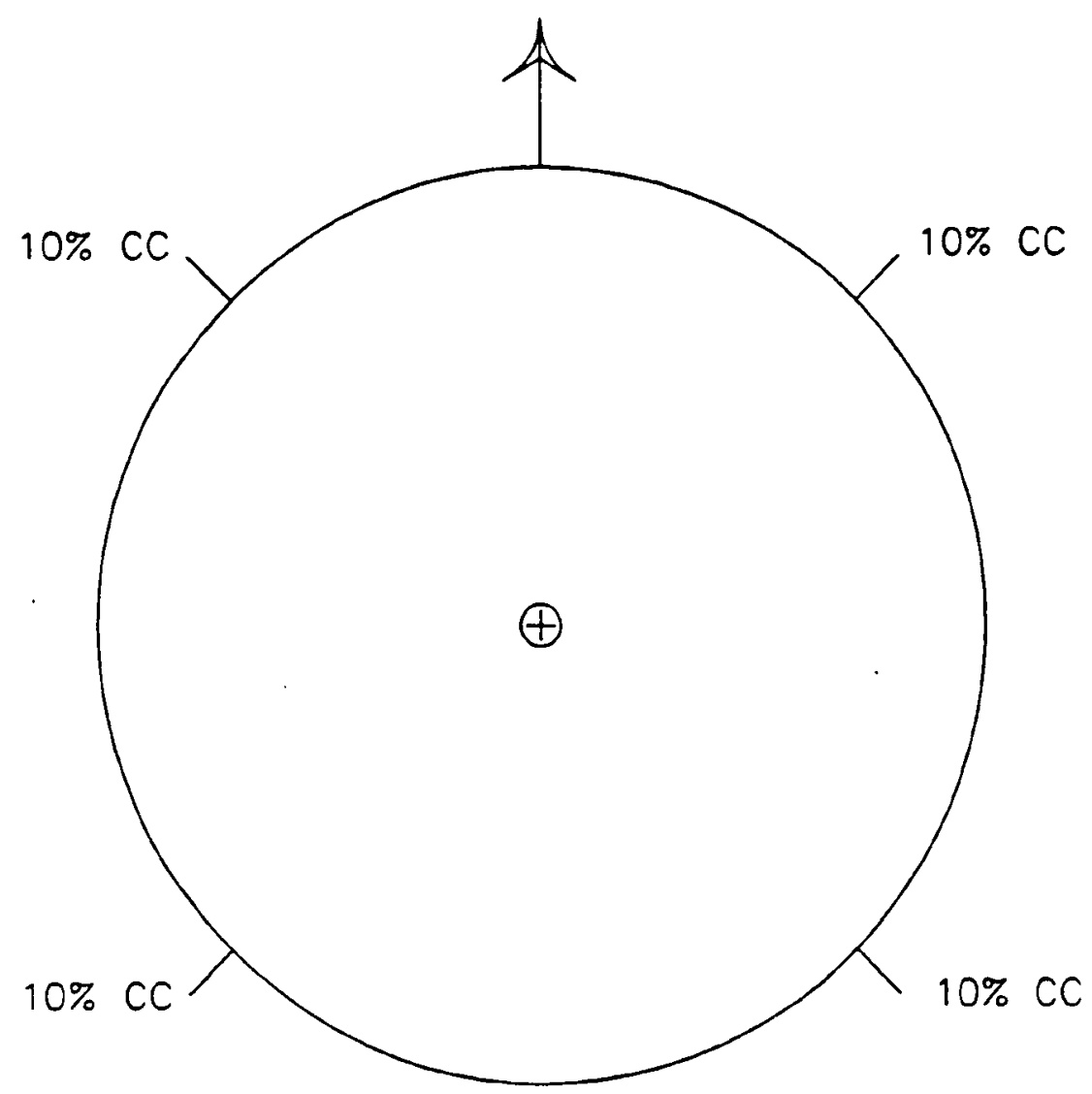

Non-nest tree site 001 .

Note: $\mathrm{PIPO}=$ ponderosa pine $\mathrm{CC}=\%$ canopy closure. 
KEY:

$+\quad=$ Nest Tree
$\bigcirc=$ PIPO

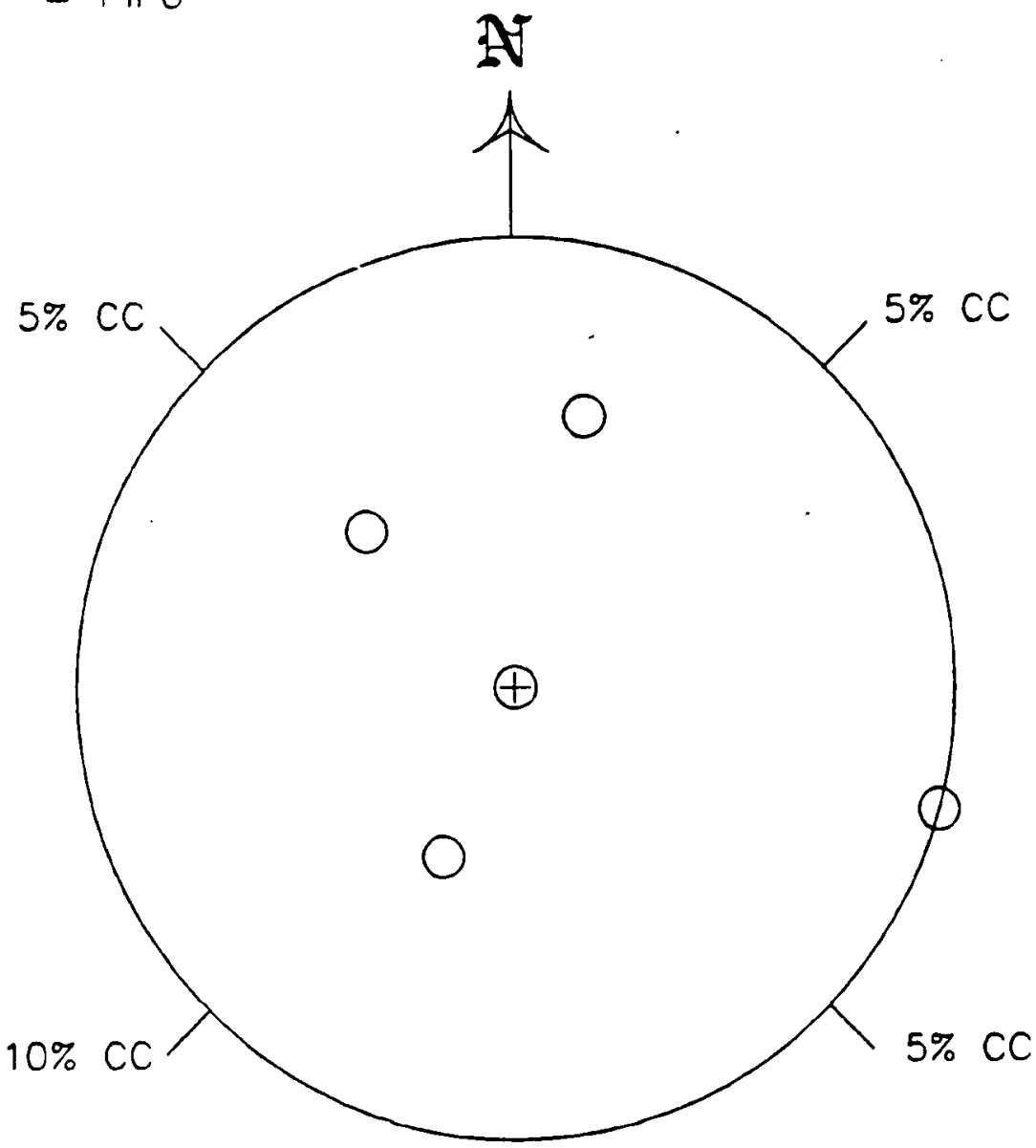

Non-nest tree site 002 .

Note: $\mathrm{PIPO}=$ ponderosa pine $\mathrm{CC}=\%$ canopy closure. 


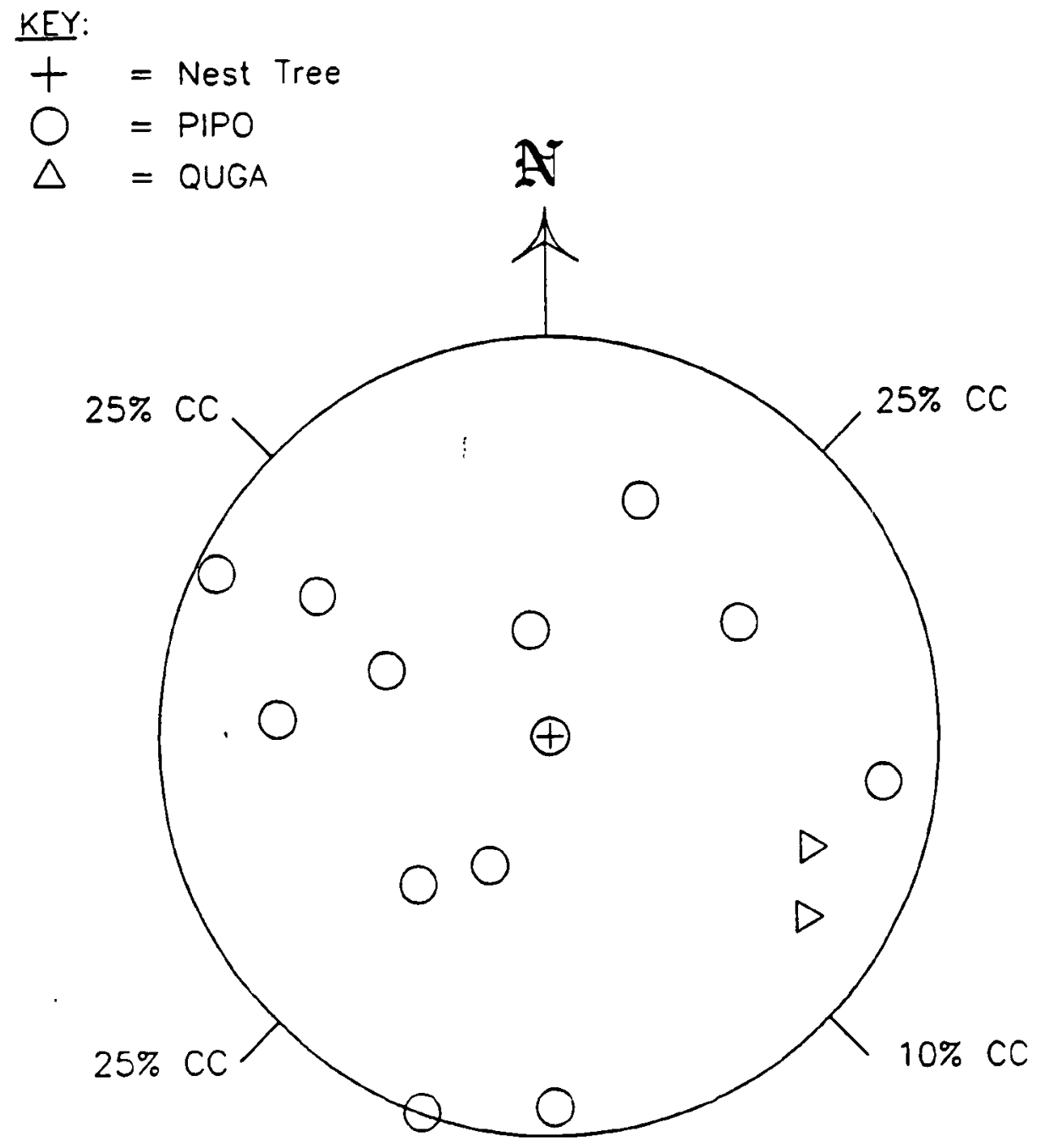

Non-nest tree site 003.

Note: PIPO = ponderosa pine; QUGA = Oregon white oak;

$\mathrm{CC}=\%$ canopy closure. 
APPENDIX D

NEST BOX DESIGN 


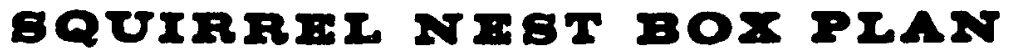

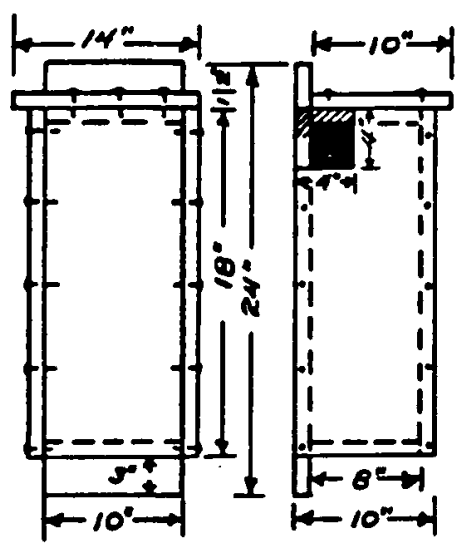

Front

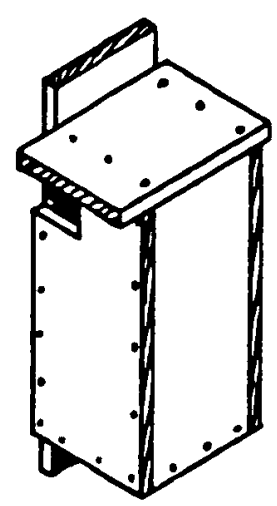

side

MATERIAL LIST

Rough I" Lumber 9'-10'

Deck $24^{\prime \prime} \times 10^{\circ}$

Front $18^{\prime \prime} \times 10^{\prime \prime}$

SI des (2) 18" $\times 10^{\prime \prime}$

lotton 8" $\times 10$ "

LId $14^{\prime \prime} \times 10^{\prime \prime}$

Ho Clear $81 \times 10^{11}$

Molls Colvenized

8013 per side

6d 3 in front -29

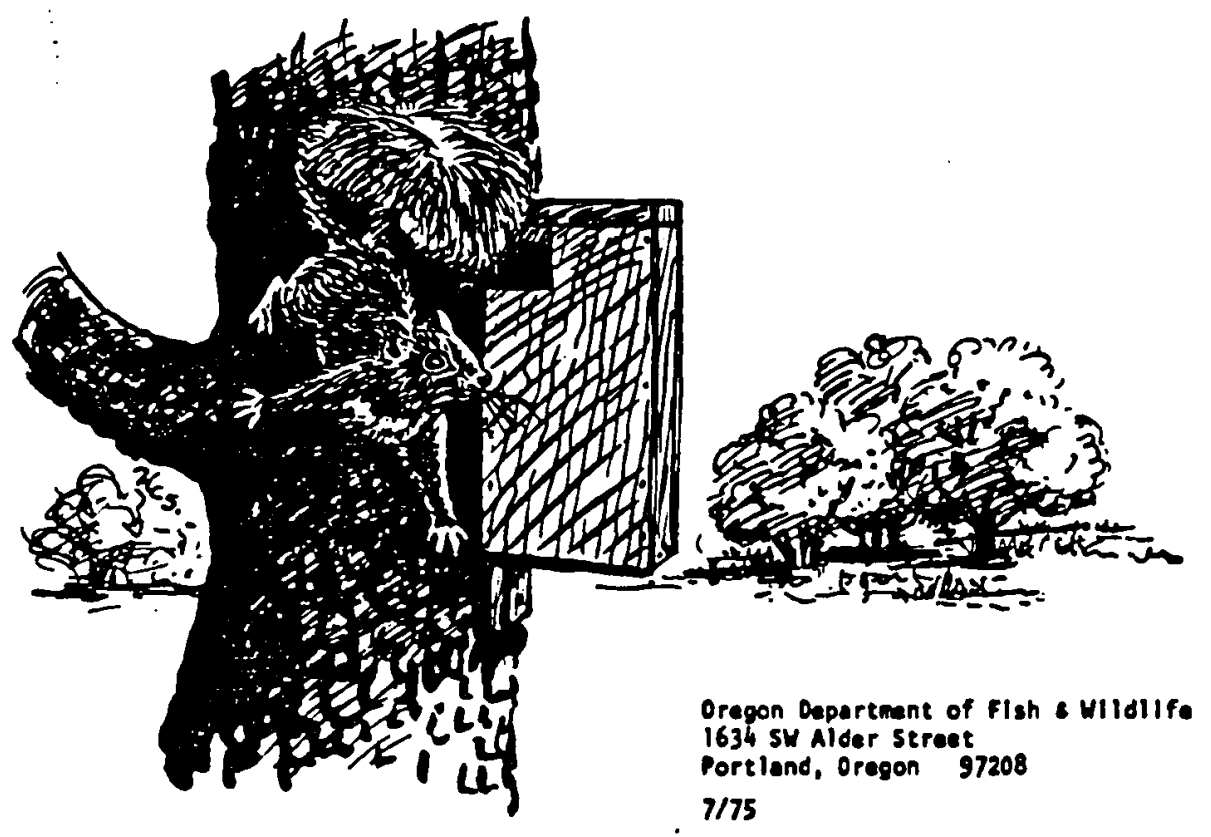

